\title{
SAFE STORAGE GUIDELINES FOR DURUM WHEAT
}

\author{
BY
}

\section{NITHYA UDAYAKUMAR}

\author{
A Thesis \\ Submitted to the Faculty of Graduate Studies in \\ Partial Fulfillment of the Requirements for the Degree of
}

MASTER OF SCIENCE

Department of Biosystems Engineering University of Manitoba

Winnipeg, Manitoba

(C) February, 2008 


\title{
THE UNIVERSITY OF MANITOBA
}

\author{
FACULTY OF GRADUATE STUDIES \\ $\dot{*} * * * *$ \\ COPYRIGHT PERMISSION
}

SAFE STORAGE GUIDELINES FOR DURUM WHEAT

BY

Nithya Udayakumar

\begin{abstract}
A Thesis/Practicum submitted to the Faculty of Graduate Studies of The University of Manitoba in partial fulfillment of the requirement of the degree
\end{abstract}

\section{MASTER OF SCIENCE}

Nithya Udayakumar (C) 2008

Permission has been granted to the University of Manitoba Libraries to lend a copy of this thesis/practicum, to Library and Archives Canada (LAC) to lend a copy of this thesis/practicum, and to LAC's agent (UMT/ProQuest) to microfilm, sell copies and to publish an abstract of this thesis/practicum.

This reproduction or copy of this thesis has been made available by authority of the copyright owner solely for the purpose of private study and research, and may only be reproduced and copied as permitted by copyright laws or with express written authorization from the copyright owner. 


\title{
DEDICATED TO
}

\author{
My Grandparents
}




\begin{abstract}
The proper storage conditions are essential to know the safe storage period for any grain. Safe storage guidelines for durum wheat have not been developed, despite the fact that they are more susceptible to spoilage within a short period than other wheat classes. The rates of deterioration of durum wheat samples with $15,16,17,18,19$ and $20 \%$ initial moisture content (wet basis) stored at $10,20,30$ and $40^{\circ} \mathrm{C}$ for 12 wk were studied. The grain deterioration parameters, includes seed germination rate, moisture content, appearance of visible mould, invisible microflora fatty acid values (FAV) and ochratoxin production were monitored at regular intervals. From these results, safe storage guidelines for durum wheat were developed with respect to the moisture content and storage temperature. Germination rates of the samples decreased with an increase in moisture content, temperature and storage period. Visible mould was found in all high moisture samples $(17,18,19$ and $20 \%)$ stored at high temperatures. FAV of the samples increased with moisture content and storage time.
\end{abstract}

Keywords: safe storage guidelines, durum wheat, moisture content, temperature. 


\section{ACKNOWLEDGEMENTS}

I would like to thank my advisor, Dr. D.S. Jayas, for his immeasurable efforts and tremendous support in guiding this project. I wish to express my sincere gratitude to Dr. N.D.G. White, Dr. D. Abramson and Dr. J.D. House for their valuable suggestions and for serving on my Advisory Committee.

I thank the Canada Research Chairs program and the Natural Sciences and Engineering Research Council (NSERC) of Canada for providing financial support.

There are many people whom I am indebted to thank. I would like to thank Mr. Tom Nowicki, Mr. Mike Roscoe, and Mr. Randy Clear, Canadian Grain Commission for mycotoxin analysis. Thanks are due to Mr. C.J. Demianyk, Mr. Matt McDonald, Mr. Dale Bourns, Mr. Gerry Woods, and Mr. Derek Inglis for their technical assistance and suggestions during the experimental work.

I am greatly thankful to Dr. K. Alagusundaram, for his encouragement and guidance. Finally, I am the most grateful to my family for their moral support during the whole program of study. I am also thankful to Sathya, Ram, Dr. Raja, Dr. Manick, Vadi, Suresh, Chella, Mahesh, Ganesh and Senthil who assisted in the preparation of this thesis. Countless friends and associates have made their contributions, a fact that is acknowledged with sincere thanks. 
TABLE OF CONTENTS

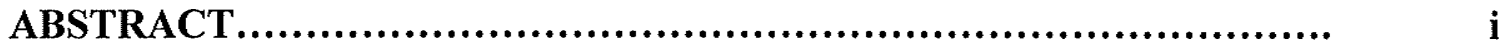

ACKOWLEDGEMENTS.................................................. ii

TABLE OF CONTENTS ................................................... ii

LIST OF FIGURES........................................................ v

LIST OF TABLES....................................................... vi

1 INTRODUCTION........................................................

1.1 Durum Wheat Production and Post Harvest Operations................ 1

1.2 Safe Storage Time............................................... 2

2 LITERATURE REVIEW............................................... 5

2.1 Wheat Storage and Conditions.................................. 5

2.1.1 Canadian wheat grading..................................... 5

2.1.2 Drying................................................. 5

2.1.3 Safe storage parameters................................ 5

2.1.4 Storage guidelines...................................... 6

2.2 Quality Assessment Parameters................................. 7

2.2.1 Respiration............................................ 7

2.2.2 Fatty acid values (FAV) ..............................

2.2 .3 Germinability .........................................

2.3 Fungal Growth and Mycotoxin Production......................... 9

2.3.1 Storage conditions predisposing grain to fungal damage....... 9

2.3.2 Major factors governing the growth of fungi................. $\quad 10$

2.4 Mycotoxin Production................................................ $\quad 12$

2.4.1 Mycotoxins...........................................

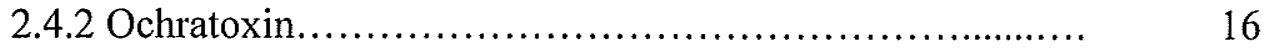

2.4.3 Mycotoxin production in the field.......................... 17

2.4.4 Mycotoxin contamination during storage ................... 18

2.4.3 Physical factors......................................... 19

2.4.4 Chemical factors..................................... 20

2.4.5 Biological factors.......................................... 20

3 METHODS AND MATERIALS........................................ 23

3.1 Experimental Design......................................... 23

3.1.1 Durum wheat samples........................... 23

3.1.2 Storage variables................................... 23

3.1.2.A Temperature.............................. 23

3.1.2.B Moisture content.......................... 24

3.2 Experimental Set up.............................................

3.2.1 Sampling frequency............................. $\quad 25$

3.3 Grain Quality Assessment......................................

3.3.1 Germination..................................... 25

3.3.2 Moisture content...................................... 26

3.3.3 Visible and invisible mould....................... $\quad 26$

3.3.4 Free fatty acid...................................... $\quad 27$

3.4 Ochratoxin Analysis......................................

3.4.1 Sample preparation............................. $\quad 27$ 
3.4.2 Extraction and centrifugation..................... 28

3.4.3 HPLC analysis................................... 28

3.5 Statistical Analysis.................................... 29

4 RESULTS AND DISCUSSION........................................ 31

4.1 Germination........................................... 31

4.2 Moisture Content...................................... 35

4.3 Microflora................................................. 38

4.4 Fatty Acid Value.......................................... 40

4.5 Ochratoxin............................................. 44

4.6 Estimated Safe Storage Life of Durum Wheat.................. 46

5 CONCLUSIONS......................................................... 48

6 RECOMMENDATIONS FOR FUTURE RESEARCH................... 50

7 REFERENCES......................................................... 51

APPENDIX A: Germination data ........................................ 55

APPENDIX B: Moisture content data..................................... 64

APPENDIX C: Invisible mould data.................................... 73

APPENDIX D: Fatty acid value data ................................... 98

APPENDIX E: Ochratoxin data....................................... 103 


\section{LIST OF FIGURES}

Fig. 1. Favorable conditions for field mycotoxin production....................... 17

Fig. 2. Five different stages in which mycotoxins can occur in human food and animal

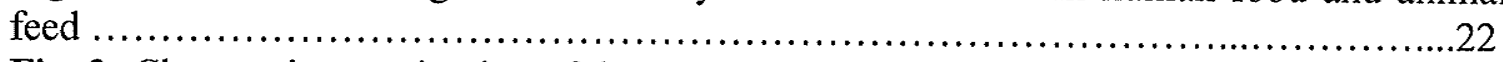

Fig. 3. Changes in germination of durum wheat with respect to time at (a) $10^{\circ} \mathrm{C}$

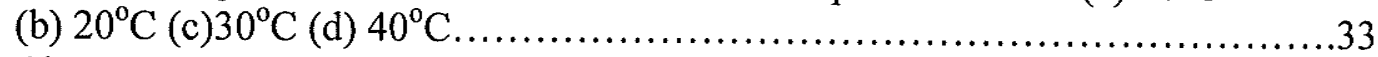

Fig. 4. Changes in moisture content of durum wheat with respect to time at

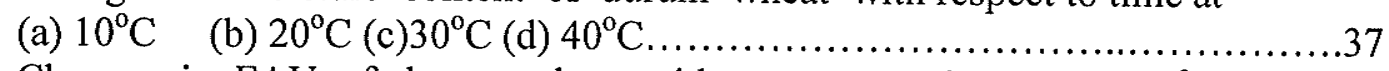

Fig. 5. Changes in FAV of durum wheat with respect to time at (a) $10^{\circ} \mathrm{C}$

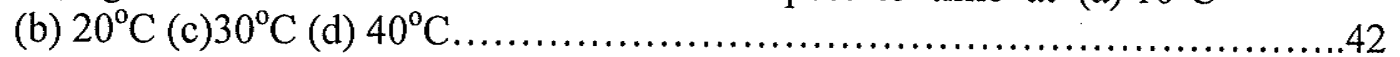

Fig. 6. Estimated safe storage life of durum wheat......................................

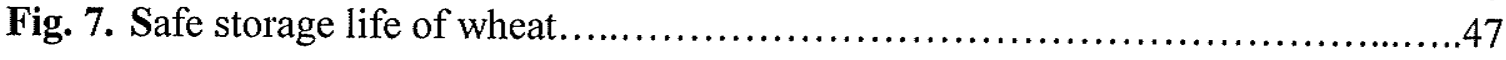




\section{LIST OF TABLES}

Table 1. Important mycotoxins, the fungal species responsible and main commodities affected............................................. 14

Table 2. Fungi which produce mycotoxins classified by habitat................15

Table 3. Factors affecting mycotoxin formation in the field, during harvest and drying, and in storage ..................................21

Table 4. Time of the first appearance of visible mould (wk) and respective germination $(\%)$ of durum wheat......................... 38

Table 5. Ochratoxin in durum wheat stored at $10^{\circ} \mathrm{C}$ (Replicate 1$) \ldots \ldots \ldots \ldots . . .45$

Table 6. Ochratoxin in durum wheat stored at $20^{\circ} \mathrm{C}$ after 12 weeks.............45 


\section{INTRODUCTION}

\subsection{Durum Wheat Production and Post Harvest Operations}

Wheat is the world's most widely grown cereal crop and is a major food staple for most of the world. Global durum wheat (Triticum durum) production for 2005-06 was 35.9 Mt (million tonnes), with Canada contributing 4.4 Mt. Durum wheat production in Canada is gradually increasing over the years and exports are likely to rise by $15 \%$ for the $2007-08$ crop year, the highest since 1998-99 which is due to increased demand for good quality durum world wide (CWB 2007). This huge amount of wheat produced has to be stored at one point of time or other for future purposes.

Usually moisture content and temperature during harvest of wheat are $20-35 \%$ and 10 $35^{\circ} \mathrm{C}$, respectively. But these conditions are not conducive for storage of wheat for long periods. Thus, the harvested wheat has to be dried and cooled before storing, a common practice in Canada (CWB 2005). In some years weather may preclude harvesting of wheat. For example, in the year 1996, due to wet autumn weather, only $50 \%$ of the cultivated wheat crop was harvested (Anonymous 1997). Increased moisture content due to high precipitation during harvest and wet conditions causing delay in harvesting grain before winter can create difficult situations for proper storage of grains. Sometimes even dry grain can experience high moisture pockets due to moisture migration (Jayas 1995). Safe storage life of grains is highly dependent on its moisture content and temperature and they need to be correlated to develop safe storage guidelines. 


\subsection{Safe Storage Time}

Moisture content and temperature of the grain are the essential parameters that determine the storage life of grain. The freshly harvested warm and moist grain should always be conditioned to acquire dry and cool grain, suitable for safe storage. Hence, drying or cooling the grain before storing or sending for further processing is an essential step. The choice of drying or cooling depends on the initial conditions of the harvested grain. If the moisture content and temperature of the grain is such that it can be kept for a long enough period without spoilage, ambient air drying in the bin with fans reduces the energy cost involved in drying. On the other hand, if the conditions of the harvested grain favor quick spoilage, heated air drying helps to dry the grain rapidly. The initial conditions of the harvested grain, and the time available before spoilage determines the choice of post harvest treatments.

In general, high temperature and high moisture grain will allow a very short time for post harvest operations. It becomes essential to determine the allowable time before spoilage for a wide range of moisture contents and temperatures. This would help farmers by informing them of the number of days before which the grain has to undergo post harvest treatments. This ensures that the quality of grain be maintained throughout the storage. Hence, only good quality grain will be sent to further processing to provide safe and nutritive products for the consumers. For animal feeds, higher deterioration is accepted than in the grain intended for human use. 
Although durum wheat contributes only $19 \%$ of the total global wheat production, even a small decrease in production can have a huge impact on the food economy, as durum serves as a staple food for a large population because of its unique pasta-making characteristics (Lennox 2005). It is essential to develop storage guidelines to minimize losses and maintain a sustained supply of durum wheat. The safe storage guidelines will help farmers to determine the number of days in which the grain has to be dried for a particular temperature moisture combination (Karunakaran 1999). The time period for which the grain can be stored safely without deterioration or without any significant loss in its quality and quantity is known as the safe storage time.

Cereals must be protected from both field diseases and fungal invasion during storage to maintain a high quality supply of grain. Various species of fungi are a serious threat to the stored grain. Fungi cause heating, deterioration, and reduction in germination, so it becomes essential to prevent fungal infection during storage. Though moulds can grow on the stored wheat over a wide range of temperatures and moisture, they thrive at high temperatures and moistures. At these conditions many filamentous fungi grow and produce some chemical substances during their metabolism, apart from decreasing the quality of grain. Certain toxigenic fungi under conducive environmental conditions produce mycotoxins, a toxic chemical metabolite which poses a great risk to human and animal health when consumed. Cereal such as wheat, barley, rye and maize, and oilseeds, are the most affected by fungi and mycotoxins of all the crops being grown (Smith and Henderson 1991). The maximum allowable limits of mycotoxins in cereal and cereal 
products are minuscule (5-10 ppb) and so it becomes essential to prevent the growth of fungi and hence production of mycotoxins in cereal grains during storage.

The quality assessment factors of stored grain which could be monitored are the seed germination, fat acidity value (FAV) (free fatty acid levels), appearance of mould growth; physical appearance and nutritive values. Changes in quality of stored grain have been studied for various grains and oilseeds (Pomeranz 1992, Mills 1996, Karunakaran 1999, White et al. 1999). Although safe storage guidelines are available for wheat with respect to moisture content and temperature, nothing had been reported for durum wheat. The existing guidelines for wheat consider a moisture content range of $10-18 \%$ and temperature range of $5-45^{\circ} \mathrm{C}$ (AAFC 2002). As there are no standard guidelines for durum wheat, the objective of this study was to study the rate of deterioration of durum wheat and develop a safe storage guideline by monitoring the quality changes when stored at different moisture and temperature conditions. 


\section{LITERATURE REVIEW}

\subsection{Wheat Storage and Conditions}

\subsubsection{Canadian wheat grading}

The quality of harvested grain is normally defined in terms of its physical attributes, sanitary conditions and its intrinsic properties. The Canadian grading system is based on the wheat's bulk density, varietal purity, vitreousness, soundness, and the amount of foreign materials present in the wheat. Other measures also include dockage, moisture content of wheat, and protein content (CIGI 1993).

\subsubsection{Drying}

During harvest, the moisture content of the grain is higher than the safe storage moisture content. Drying is the most important step carried out in lowering the moisture content. This is usually accomplished by cutting the grain and leaving it in swaths until dry. This does not work during wet harvests. Artificial drying has some added advantages of extending the available harvest period, reducing field loss of grain by promoting earlier harvest, and reducing spoilage risks thereby improving marketability and acceptability of grain (Bala 1997). Near ambient or heated air can be used for this purpose with the choice depending on the available time and the moisture content of the grain at harvest.

\subsubsection{Safe storage parameters}

Certain pre-storage parameters such as date of harvest, condition of grain during harvest and drying methods, affect the quality of wheat during storage and thereafter, but the most deleterious change in quality occurs due to improper storage conditions. Safe 
storage of any grain is mainly dependent on two primary factors, temperature and moisture content of the grain. Many factors that are also considered important during the storage are: the length of storage, carbon dioxide levels $\left(\mathrm{CO}_{2}\right)$, oxygen $\left(\mathrm{O}_{2}\right)$ levels, microorganisms, grain characteristics, insects, mites, rodents, birds, granary or bin spatial location, and geographical location (Jayas 1995). All these storage parameters can be broadly classified as biotic and abiotic factors. Moisture content and temperature of the grain, intergranular gas composition, engineering properties of grain, and the type of storage structure are the factors that are considered abiotic (which do not involve any living substance). The factors which account for the living part of the grain and its atmosphere such as, the grain itself, microorganisms, insects, mites, rodents, and birds constitute the biotic part of the grain ecosystem (Mills 1996). There always exists an interrelation between the biotic and abiotic parameters; with the abiotic variables influencing the presence and development of biotic variables or causing the deterioration of grain due to improper interaction with the biotic parameters.

\subsubsection{Storage guidelines}

Moisture content and temperature are the most important parameters that will decide the safe storage period of any product. The respiration rate of grain, growth and development of moulds and insects are mainly dependent on moisture content (water activity or relative humidity) during storage; with most of the nutritive and energy content of wheat kernels consumed by the deteriorative organisms (Tipples 1995). Jayas and White (2003) confirmed that high moisture content accelerates the deterioration in grain followed by high storage temperature. Storing grain at moisture content and temperature higher than 
the safe limit leads to increased multiplication of mites and microflora with rapid spoilage (Wallace et al. 1983). Warm moist grain supports the growth and multiplication of insects, mites and fungi, which during respiration produce heat, carbon dioxide, and moisture leading to further deterioration of grain (White and Sinha 1980). Moisture and temperature play a major role in the degradation of insecticides used on grain inside the bin (White 1995). Wheat stored at low moisture content of $11.9 \%$ for sixteen years was sound, without any growth of microorganism (Pixton et al. 1975). Moisture content is the primary factor to be considered for the safe storage of any grain.

\subsection{Quality Assessment Parameters}

\subsubsection{Respiration}

Even after harvest, the seed is a living organism which continues the metabolic process of respiration. Aerobic respiration occurs during the presence of oxygen where carbohydrate and fat oxidation occurs with production of water, carbon dioxide and energy. In the case of interruption in the oxygen supply to the grain, anaerobic metabolism can occur in wet grain. This process is called fermentation, and results in products like carbon dioxide, gas and organic compounds like alcohols (Santin 2005). Temperature and humidity of grain determines the intensity of the respiration process. When temperature increases, respiration rate increases by 2 or 3 fold for every $10^{\circ} \mathrm{C}$ rise (White et al. 1982); and stops with higher temperature as it destroys the enzymes needed for respiration. At low temperatures the respiration rate will be less, but refrigerating or storing grain at cool temperatures will not stop the growth of some fungi as long as temperatures are above $0^{\circ} \mathrm{C}$. Respiration and heating can be associated with the deterioration of grain and hence 
carbon dioxide levels above $2 \%$ in the air of a grain mass is considered an important indicator of grain spoilage (Sinha et al. 1986).

\subsubsection{Fatty acid values (FAV)}

During storage, many biochemical changes occur that may alter or lower the nutritive value of the stored product by changing the carbohydrates, proteins, lipids and vitamins. Lipids undergo oxidative or hydrolytic changes and produce certain compounds that may produce off flavor or odor in the final product. Hence this change in lipid structure or the lipid compounds can be used for monitoring the quality of the product during storage. Lipids in stored grain often undergo hydrolysis which is stimulated by the enzymes secreted by the microorganisms present in the grain. During hydrolysis, breakdown of lipids takes place producing free fatty acids (FFA). If the deterioration of grain is increased due to more growth of microorganisms, FFA are produced at a faster rate. Thus the free fatty acid value can be correlated to the amount of microorganisms present in the grain and can act as a deterioration index. FFA is positively correlated with moisture and negatively correlated with temperature (Wallace et al. 1983). The amount of $\mathrm{KOH}$ or mg $\mathrm{KOH}$ required to neutralize the fiee fatty acid in $100 \mathrm{~g}$ of moisture free seeds is normally referred to as the fat acidity value. Fatty acid value can be expressed as the relative change to freshly harvested grain to correlate with deterioration (Sinha 1983).

\subsubsection{Germinability}

Germination of the grain is very important in determining the changes in quality of grain during storage as germinability is the first and foremost factor most likely to change due 
to poor storage conditions (Pomeranz 1992). When the germination of stored grain reaches $90 \%$ of the initial germination, it is an indication that mould has started to grow; and a germination drop to $85 \%$ of initial germination indicates that the grain has started to downgrade. The quality measurements done to test the condition of grain and the extent of deterioration can include FFA value, mycotoxin, chitin and ergosterol content; and microfloral species identification often requires expensive equipment and needs trained personnel. A simple test which can be performed at the farm level by the farmers, and which will give fast information is always necessary. Though inspection of grain for visible mould is fast and easy, it is not always reliable. Even before the occurrence of visible mould germination can be affected and so for measuring the changes in quality of stored grain, germination can be considered the most sensitive technique and can be done easily on farm.

\subsection{Fungal Growth and Mycotoxin Production}

\subsubsection{Storage conditions predisposing grain to fungal damage}

The extent of mould colonization depends on the temperature, $\mathrm{O}_{2}$ and $\mathrm{CO}_{2}$ concentrations, and moisture content of the stored product. A minimum oxygen concentration of $1-2 \%$ is essential for growth of almost all fungi, with an exception of $0.5 \%$ oxygen concentration and $60 \% \mathrm{CO}_{2}$ for Fusarium verticillioides (Tuite 1994). Moisture content and temperature are the key factors that determine fungal growth. An optimal temperature range for most fungal growth is between 20 and $30^{\circ} \mathrm{C}$ and maintaining a temperature lower than this will be difficult if the grain temperature is high during harvest and if aeration systems are not available (Santin 2005). Storage moisture 
content in the range of $15-18 \%$ provides a favorable condition for fungal invasion. In oilseeds and grains with high oil content, fungal growth can occur even at moisture content as low as 7\% wet mass basis (Tuite 1994). The inter-granular water vapor inside the storage bin can also be utilized by the moulds as a source of moisture.

The chance of fungal infection during storage can be prompted by certain management practices aimed to reduce the fungal growth. During high temperature drying, intended to reduce moisture content of the grain, the protective pellicle layer of the seed (seed coat layers) breaks up, exposing the endosperm which helps mould invasion. Physical damage to grain caused by insects and mites and excessive handling also expose the endosperm which predisposes grain to mould invasion. Insect and mite infestation increases the temperature and moisture content of the infested grain due to their metabolic activity, which stimulates fungal growth and development. The faecal material of insects and mites can also act as an additional substrate for mould growth.

\subsubsection{Major factors governing the growth of fungi}

The growth of fungi in stored products is principally governed by the following factors (Pitt and Hocking 1985):

- Water activity

- Hydrogen ion concentration (acidity)

- Temperature

- Gas tension

- Consistency 
- Nutrient status

- Preservatives

\section{Water activity $\left(\mathbf{a}_{\mathbf{w}}\right)$}

The growth of microorganisms in a stored product, in relation to its moisture content can be quantified by water activity (Scott 1957). Water activity $\left(a_{w}\right)$ can be explained as a value that when expressed as a decimal, is numerically equal to the equilibrium relative humidity (ERH). Practically, the stability of any stored product is determined by $a_{w}$, as it is the dominant environmental factor that controls the fungal growth in a product. Thus, in predicting the storage life of commodities a thorough knowledge of fungal water activity relationships becomes essential. The water activity relations of fungi to produce a mycotoxin can help us in understanding the conditions under which mycotoxins can develop. As every other organism, fungi require water for their growth; and most fungi can grow at minimum $a_{w}$ of 0.85 , while xerophilic fungi can grow down to $0.75 a_{w}$.

\section{Temperature}

Temperature plays a major role in fungal growth but in practical situations storing commodities in a safe temperature is not always possible and generally, storage is done under conditions favorable for fungal growth. While higher storage temperatures support the growth of storage fungi such as Aspergillus species, temperatures below $20^{\circ} \mathrm{C}$ favor the growth of cold tolerant fungi such as Penicillium species. In stored products, Aspergillus species are the most dominant fungi in tropical regions; and in temperate conditions Penicillium species are the most dominant fungi. 


\section{Gas tension}

Modifying the storage atmosphere is one method for insect control. This is an important factor to be considered during storage of commodities as reduction in oxygen tension or increase in carbon dioxide concentration decrease the growth of fungi profoundly.

\section{Preservatives}

Raw stored products, used for human consumption, should be free of chemical residues or preservatives such as propionic acid. In certain circumstances, the presence of trace amount of insecticides and fumigants becomes unavoidable. The effect of these chemicals on the growth and development of storage fungi has not yet been validated (Pitt and Hocking 1996). Inhibiting fungal growth by storing the commodities at a low $a_{w}$ is usually efficient and cost effective.

\section{Combination of factors}

All the above mentioned factors are often synergistic and may not always act independently. When more than two of these factors are managed simultaneously, a longer storage period than expected becomes feasible. On the whole, for increased storage life of commodities, a combination of factors with low $\mathrm{a}_{\mathrm{w}}$ and low temperature with reduced oxygen or increased carbon dioxide levels have proven effective.

\subsection{Mycotoxin production}

\subsubsection{Mycotoxins}

Mycotoxin is a generic term used to describe the secondary metabolites produced by fungi to inhibit the growth of other fungi. Mycotoxins include various compounds of low molecular weight which have diverse chemical structure and biological activities. Table 1 
shows the various mycotoxins and their major food sources. Fungal growth and mycotoxin production can occur when the crop is in the field or after harvest and during storage. Mycotoxins are a major problem in countries with high temperature or humidity and poor harvest, and storage conditions. The major human intake of mycotoxins occurs through consumption of mycotoxin-containing plant based foods, and foods of animal origin, such as milk, cheese, and certain fermented meat products, because often the animals have fed on contaminated grain.

Once the mycotoxins enter the biological cycle, in either human or animals, the action of mycotoxins is mediated through a number of organs, and is referred to as Mycotoxicosis; whereas an invasion of the growing fungi on any living tissue is referred to as mycosis (CAST 2003). Mycotoxins often exhibit various biological effects that include acute and chronic toxicity such as carcinogenic, mutagenic, tetratogenic and immunotoxic. At low levels they do not produce any symptoms or signs of poisoning. Aflatoxins are the most common mycotoxin occurring in nuts, dried fruit such as figs, spices, peanuts, corn, and cereals. Other toxins include ochratoxin, deoxynivalenol, nivalenol, trichothecenes, zearalenone, alternariol and tenuazonic acid (in oilseeds), sterigmatocystin, fumonisins and patulin. Although in stored cereal grain occurrence of ochratoxin was confirmed in many surveys, due to misidentification of the fungi that form ochratoxin, further research was not carried out (Scudamore et al., 1999). 
Table1. Important mycotoxins, the fungal species responsible and main food commodities affected

\begin{tabular}{|c|c|c|}
\hline Mycotoxin & Main fungal species & Foods affected \\
\hline Aflatoxins $B_{1}, B_{2}, G_{1}, G_{2}$ & $\begin{array}{l}\text { A. flavus, } A \text {, parasiticus }{ }^{\mathrm{a}} \\
\mathrm{a}=\text { aflatoxin } \mathrm{B}_{1} \text { and } \mathrm{B}_{2} \text { only }\end{array}$ & $\begin{array}{l}\text { Cereals, nuts, figs, dried } \\
\text { fruit, spices, rice bran, } \\
\text { maize }\end{array}$ \\
\hline Aflatoxins $M_{1}, M_{2}$ & $\begin{array}{l}\text { Metabolic products of } B_{1} \\
\text { and } B_{2}\end{array}$ & Milk and diary products \\
\hline Sterigmatocystin & A. versicolor, $A$. nidulans & $\underline{\text { Cereals, cereals, cheese }}$ \\
\hline Cyclopiazonic acid & A. flavus, P. commune & $\frac{\text { Cereals, }}{\text { cheese }}$ pulses, nuts, \\
\hline Ochratoxin A & $\begin{array}{l}P . \text { verrucosum, } A \text {. } \\
\text { ochraceus }\end{array}$ & $\frac{\text { Cereals, coffee beans, field }}{\text { beans, beer, nuts }}$ \\
\hline Citrinin & $P$. verrucosum & Cereals \\
\hline Patulin & P. expansum & Apple juice, fruits \\
\hline Deoxynivalenol, nivalenol & $\begin{array}{l}F . \text { graminearum, } F . \\
\text { culmorum, } \\
F . \text { crookwellense }\end{array}$ & Cereals \\
\hline T-2 toxin, HT-2 toxin & F. sporotrichioides, $F$. poae & Cereals \\
\hline Fumonisins $B_{1}, B_{2}, B_{3}$ & $\begin{array}{l}F . \text { moniliforme, } \\
F . p r o l i f e r a t u m\end{array}$ & Maize, maize products \\
\hline Zearalenone & $\begin{array}{l}\text { F.graminearum, } F \text {. } \\
\text { culmorum, } \\
\text { F. crookwellense }\end{array}$ & Cereals \\
\hline Moniliformin & Fusarium species & $\underline{\text { Cereals }}$ \\
\hline $\begin{array}{l}\text { Alternariol, alternariol } \\
\text { Monolethyl ether, } \\
\text { Tenuazonic acid }\end{array}$ & $\begin{array}{l}\text { Alternaria alternata, } \\
\text { A.tenuis }\end{array}$ & $\frac{\text { Cereals, fruits, tomatoes, }}{\text { oilseeds }}$ \\
\hline Ergot alkaloids & Claviceps purpurea & Cereals \\
\hline
\end{tabular}

Source: Scudamore et al., (1999) 
Ochratoxin gained more importance when the Committee of Toxicity (COT) classified them as a potential carcinogen and recommended the reduction of allowable limits of ochratoxin in cereals. Moreover, unlike other mycotoxins, ochratoxin is very stable during processing which also necessitates further research for reducing the levels of ochratoxin in cereal and cereal products.

The knowledge of storage conditions favorable for the growth of each of the mycotoxigenic fungi can be used to prevent the growth of fungi and mycotoxin production. An optimal growth condition of one strain of fungi will always be different to another strain in storage. Table 2 enumerates the major fungi that can produce mycotoxins on various substrates.

Table 2. Fungi which produce mycotoxins classified by habitat

\begin{tabular}{cl}
\hline Type of substrate & \multicolumn{1}{c}{ Fungal strain } \\
\hline Living plant & $\begin{array}{l}\text { Aspergillus flavus, Claviceps purpurea, Sclerotinia sclerotiorum, } \\
\text { Fusarium graminearum, Rhizoctonia leguminicola }\end{array}$ \\
& Fusarium graminearum, Alternaria longipes, Stachybotrys atra, \\
Decaying plant & Fusarium sporotrichoides, Cladosporium sp. \\
& Aspergillus flavus, A. paraciticus, A. versicolor, A. ochraceous, \\
Stored products & Penicillium citrinum, P. rubrum, P. cyclopium, P. verruculosm, \\
& Fusarium graminearum, F. moniliforme, F. nivale
\end{tabular}

Source: Hesseltine (1976) 


\subsubsection{Ochratoxin}

Ochratoxin is a collective term for a group of mycotoxins produced predominantly by $A$. ochraceous and Penicillium verrucosum, in tropical and temperate regions, respectively. A temperature range of $0-30^{\circ} \mathrm{C}$ with an optimum of $20^{\circ} \mathrm{C}$; and a water activity of 0.83 and above are the most critical parameters for the production of this mycotoxin. Studies have shown that Aspergillus spp. produce ochratoxin at $12-37^{\circ} \mathrm{C}$, and $\mathrm{pH}$ more than 2.2 and water activity of 0.80 (Adebajo et al. 1994, Wheler et al. 1991); and Penicillium spp. at $4^{\circ} \mathrm{C}$ and water activity of 0.86 (Sweeney and Dobson 1998).

Ochratoxin is relatively newly recognised compared to other mycotoxins and is posing threats to both human and animal health. Ochratoxin A is the most common and most toxic contaminant in cereal grains and there are several analogues of ochratoxin A like ochratoxin B, $C$, $\alpha$ and $\beta$. Ochratoxins are very common in stored grains in temperate areas, when grains are not dried properly (Lombaert 2003). A maximum limit of $5 \mu \mathrm{g}$ of Ochratoxin A in $1 \mathrm{~kg}$ cereal (ppb) has been proposed by the World Health Organization. It is expected that a maximum level of $5 \mu \mathrm{g}$ of $\mathrm{OA} / \mathrm{kg}$ of cereal and cereal products will be established for world trade (JECFA1999). OA occurs in combination either with sterigmatocystin or citrinin (CIT), particularly in stored wheat, barley, oat and corn (Abramson et al. 1999). In Canada, the Provisional Tolerable Daily Intake (PTDI) for ochratoxin is proposed as $1.2-5.7 \mathrm{ng} / \mathrm{kg}$ body (ppt) weight/day. The European Union has set a limit for ochratoxin of $5 \mathrm{ppb}$ in cereals, $3 \mathrm{ppb}$ in cereal products and $0.55 \mathrm{ppb}$ in foods for babies and young children (Revankar 2003). About 55\% of the average human intake of ochratoxins is contributed by cereal grains. Ochratoxins will not produce any 
toxication symptoms at these low levels and no antidote is available for ochratoxin poisoning. Hence it is essential to prevent the production of ochratoxin during storage of cereals.

\subsubsection{Mycotoxin production in the field}

In the field, the fungi growing on the plant under favorable environmental conditions can produce mycotoxins. These are referred to as field mycotoxins.

\section{Favorable conditions for mycotoxin production}

The presence of toxigenic fungi does not mean that mycotoxins will necessarily be produced in any grain. For field production of mycotoxins, an interaction of several factors such as environment, plant and the fungal strain mainly determines the level of fungal growth and mycotoxin level. Fig.1. shows the interaction of various factors on field mycotoxin production.

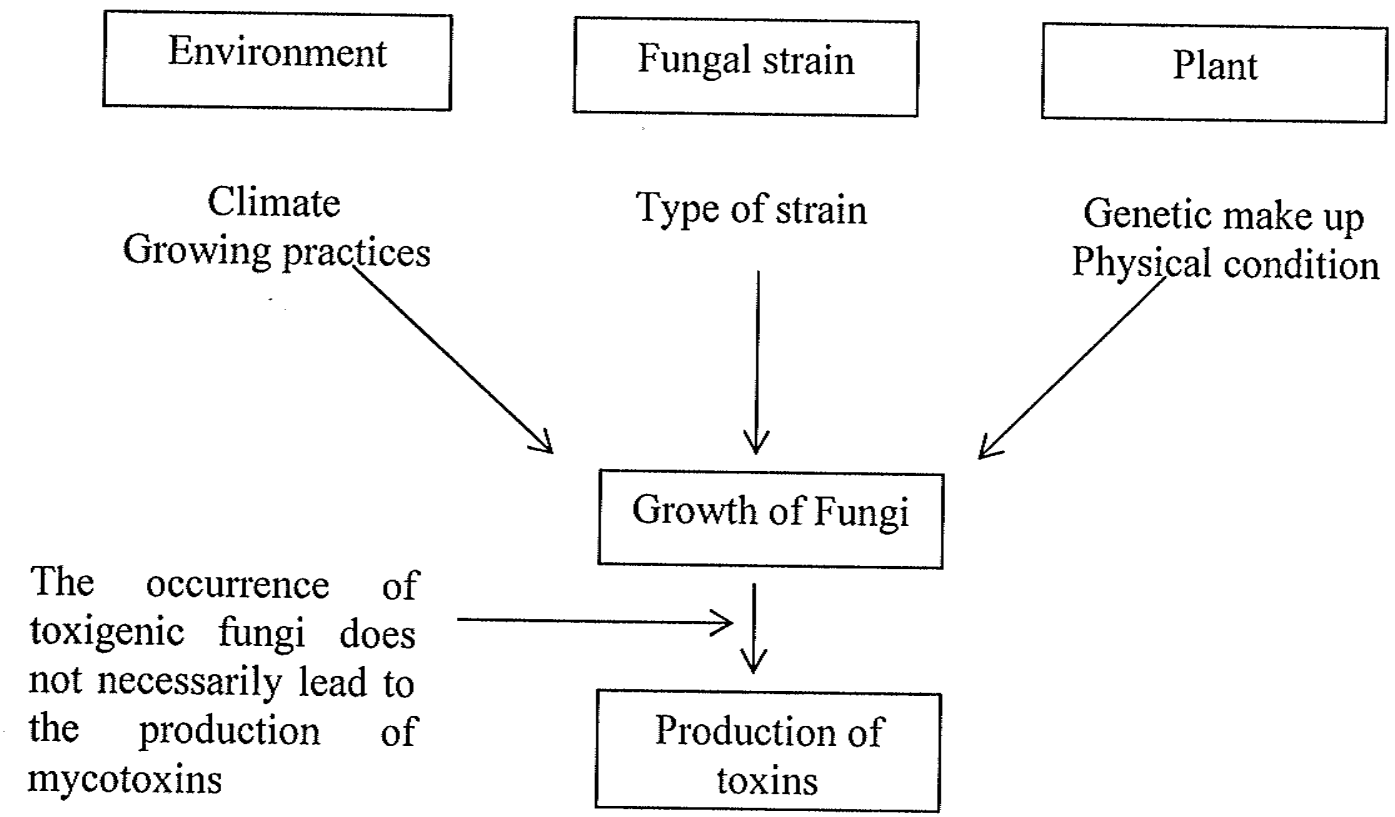

Fig.1. Favorable conditions for field mycotoxin production 


\subsubsection{Mycotoxin contamination during storage}

Mycotoxin contamination can occur in food and feedstuff in the field before harvest but most occurs during storage. Grain, nut and other products in particular, if stored at high moisture contents are likely to be infested mainly with Aspergillus and Penicillium species (Christensen and Kaufmann 1969). Storage fungi can grow in a wide range of relative humidities ranging from as low as $65 \%$ with rapid growth occurring at $85 \%$. Field fungi require very high relative humidity and cannot survive during storage. For most crops, including peanuts, with an exception of cotton, aflatoxin development and accumulation occurs only after harvest (Schroeder 1969). Low levels of pre harvest contamination by fungi are common with inoculum coming from air, soil, and handling equipment. Moisture content and temperature during storage are the deciding factors in the growth of fungi in any commodity.

Mycotoxins are produced either in the field or during storage or it can be a combination of both, depending on the commodity. Though fungal growth is essential for mycotoxin production, the presence of fungi cannot always lead to mycotoxin production. Mycotoxin production is a variable factor which also depends on a variety of parameters. The most critical aspect in preventing mycotoxin production is reducing the time required for drying the commodity. Another important factor to be considered is the chance of rewetting or remoistening of grain in the bin through leaks, condensation or other sources. When the plant is in field, formation of dew on the surface of the plant will favor spore germination and mould invasion (Wyllie and Morehouse 1978). 


\subsubsection{Physical factors}

The optimum temperature range for mycotoxin production has been determined by many researchers. Sorenson et al. (1967) concluded that aflatoxins in rice could be produced at $11^{\circ} \mathrm{C}$ to $36^{\circ} \mathrm{C}$. However, the production of aflatoxin $G_{1}$ and aflatoxin $B_{1}$ were not exactly parallel in this temperature range. Certain mould that may be present on the corn ears may not produce mycotoxin in the field, but later, when the temperature and moisture increases during the spring, mycotoxins may be produced in the bin or in the field before harvest. Mechanical injury of grain during various operations has a significant effect on the mycotoxin production by moulds. Spore germination was higher on damaged kernels than on undamaged kernels. Artificial inoculation of spores to damaged and undamaged corn ears showed that uninoculated ears which had some physical damage showed higher incidence of mycotoxin levels than inoculated undamaged ears (Lillehoj et al. 1975).

The most critical criterion that determines the storability of grains is the individual seed moisture content and not just the bin average moisture content. This becomes extremely important during blending of grain of different moisture contents to attain an average moisture content for "dry" designation in the Canadian grading system. Improper blending of moist and dry grains will favor the growth of mould in the moisture pockets. In such conditions, mycotoxin production can occur at lower average moisture levels, for example, aflatoxin production normally requires about $16-17 \%$ moisture and in blending of high and low moisture corn, aflatoxin was produced at the lower average levels of around 14\% (Lillehoj et al. 1975). Hot spots in grain bulks often have moisture sufficient enough to support the mould growth even though the average moisture content of the 
bulk is very low or dry. Once the mould spores germinate, they will produce moisture for their further development and mycotoxin production (Hesseltine 1976).

\subsubsection{Chemical factors}

The atmosphere surrounding the grain is the most important chemical factor that affects the mycotoxin production capability of moulds. A study conducted with $A$. flavus showed that aflatoxin production was lowered at low relative humidities and high carbon dioxide levels. The study also concluded that storing grain at 20 or $40 \% \mathrm{CO}_{2}$ at low temperature or relative humidity or both will completely prevent aflatoxin production. As all of the mycotoxigenic fungi require oxygen, maintaining a low oxygen level affects sporulation, spore germination and mycelium development. The type of grain (substrate) and the mineral nutrition available in the stored grain also affect fungal growth and mycotoxin production (Semeniuk 1954).

\subsubsection{Biological factors}

The susceptibility to certain fungal infection increases when the plant is under stress. Cool and humid weather conditions in the field result in growth of many field mycotoxinproducing fungi. The influence of irrigation or lack of water was studied on peanuts and the plants that suffered drought stress had increased aflatoxin production with decreased productivity. Incidence of a fungal strain on the plant will increase the susceptibility to many other fungi that may be potential mycotoxin producing strains. Insect vectors mechanically carry fungi, with certain fungi being carried through their alimentary canal. Plant varietal difference and fungal strain difference also have a prominent effect on the 
production of mycotoxin (Pettit et al. 1971). Table 3 shows the various factors that determine mycotoxin production in the field, at harvest, and during storage, and fig.2 shows the various stages at which mycotoxins can occur.

Table 3: Factors affecting mycotoxin formation in the field, during harvest and drying, and in storage

\begin{tabular}{|c|c|c|c|}
\hline Occurrence & Physical factors & Chemical factors & Biological factors \\
\hline In field & $\begin{array}{l}\text { Moisture } \\
\text { Relative humidity } \\
\text { Net evaporation } \\
\text { Temperature } \\
\text { Mechanical damage } \\
\text { Time }\end{array}$ & $\begin{array}{l}\text { Nature of substrate } \\
\text { Mineral nutrition }\end{array}$ & $\begin{array}{l}\text { Plant stress } \\
\text { Plant varietal differences } \\
\text { Spore load } \\
\text { Microbiological } \\
\text { ecosystem } \\
\text { Insect damage } \\
\text { Damage by plant disease }\end{array}$ \\
\hline $\begin{array}{l}\text { During harvest } \\
\text { and drying }\end{array}$ & $\begin{array}{l}\text { Moisture } \\
\text { Rapidity of drying } \\
\text { Rewetting } \\
\text { Relative humidity } \\
\text { Net evaporation } \\
\text { Mechanical damage } \\
\text { Blending grain } \\
\text { Hot spots }\end{array}$ & - & $\begin{array}{l}\text { Spore load } \\
\text { Insect damage }\end{array}$ \\
\hline In storage & $\begin{array}{l}\text { Moisture } \\
\text { Rapidity of drying } \\
\text { Rewetting } \\
\text { Relative humidity } \\
\text { Temperature } \\
\text { Mechanical damage } \\
\text { Blending grain } \\
\text { Hot spots }\end{array}$ & $\begin{array}{l}\text { Carbon dioxide } \\
\text { Oxygen } \\
\text { Nature of substrate } \\
\text { Mineral nutrition } \\
\text { Chemical treatment }\end{array}$ & $\begin{array}{l}\text { Plant stress } \\
\text { Plant varietal differences } \\
\text { Spore load } \\
\text { Microbiological } \\
\text { ecosystem } \\
\text { Insect damage } \\
\text { Damage by plant disease }\end{array}$ \\
\hline
\end{tabular}

Source: (FAO 1990, Twiddy 1994) 


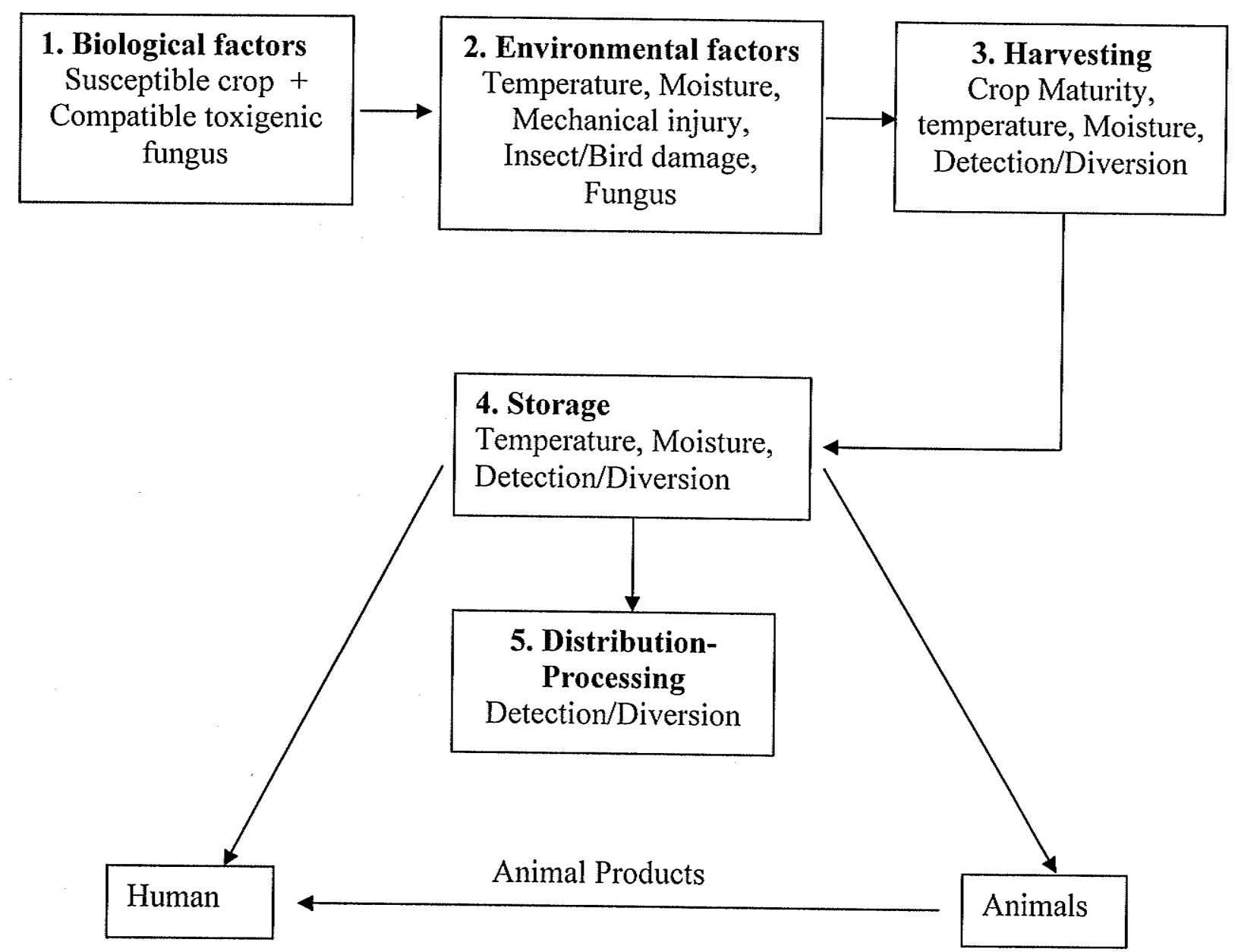

Fig 2: Five different stages in which mycotoxins can occur in human food and animal feed

(FAO 1990, Twiddy 1994) 


\section{MATERIALS AND METHODS}

\subsection{Experimental Design}

\subsubsection{Durum wheat samples}

In grain elevators, grain from various locations is usually mixed. To simulate similar conditions for the experiment, durum wheat samples from various growing regions in Saskatchewan were obtained. Durum wheat from three different locations: Moose Jaw, Swift Current and Kindersley were mixed together and used for the experiments. About $10 \mathrm{~g}$ of the whole grain sample was placed in a hot air oven at $130^{\circ} \mathrm{C}$ for $19 \mathrm{~h}$ to determine the initial moisture content of the freshly obtained wheat samples (ASAE 2003). The required moisture contents ( $\pm 0.2 \%$ for all moisture levels) for the study were achieved by adding and mixing a calculated quantity of distilled water; and the samples were stored in a plastic bag in a freezer at $-5^{\circ} \mathrm{C} \pm 2^{\circ} \mathrm{C}$ for $72 \mathrm{~h}$. To ensure the uniform moisture distribution, the grain in the plastic bag was mixed thoroughly every $3 \mathrm{~h}$ for 3 days and the final moisture was determined by a hot air oven. The samples were stored in a freezer $\left(-5^{\circ} \mathrm{C} \pm 2^{\circ} \mathrm{C}\right)$ until used for the experiments.

\subsubsection{Storage variables}

\subsubsection{A. Temperature}

The possible temperatures to which grain will be exposed during harvest and storage was considered in working out the temperature range for the study. The daily average temperature in the prairies during a normal harvest season is around $25^{\circ} \mathrm{C}$ (Muir and Jayas 1997); with the harvest temperature of wheat ranging between $5-36^{\circ} \mathrm{C}$ in Manitoba (Kawamoto et al. 1991). Prasad et al. (1978) reported that in swath, cereal grains will 
have temperature of $8^{\circ} \mathrm{C}$ greater than the ambient temperature. As the harvest temperature of the grain kernels would be maintained for a long time during storage in large bins (Jayas et al. 2004) and the temperature inside the bin varies according to the outside temperature, it becomes essential in selecting the proper temperature range for the study. During storage, if a temperature below $10^{\circ} \mathrm{C}$ is maintained, most of the common storage fungi except Penicillium will not grow. Hence a temperature range of $10-40^{\circ} \mathrm{C}$ was selected in intervals of $10^{\circ} \mathrm{C}$; i.e., $10,20,30$ and $40^{\circ} \mathrm{C}$.

\subsubsection{B. Moisture content}

In Manitoba, historically, moisture content of freshly harvested wheat ranges between 1020.5\% (Kawamoto et al. 1991). Moisture content may increase in the bin mainly due to snow and precipitation. When snow melts or rain enters in the bin, the water is absorbed in the top $30 \mathrm{~cm}$ or may trickle down to the bottom. This results in pockets of high moisture content in the grain bulk. Upward moisture movement from concrete floors will also result in accumulation of moisture at the bottom of the bin. The change in moisture can also be due to convection currents which also lead to localized spoilage. Hence higher moisture contents were also considered in selecting the moisture content range for this study. The straight grade of wheat is $14.5 \%$ moisture content (m.c.), therefore straight grade moisture or less is often safe for storage. For this study moisture contents greater than $14.5 \%$ were used: $15,16,17,18,19$ and $20 \%$ m.c., wet mass basis. 


\subsection{Experimental Setup}

All experiments were done in environmental chambers (CONVIRON, Controlled Environments Limited, Winnipeg, $\mathrm{MB})$ maintained at $10,20,30$ and $40^{\circ} \mathrm{C}\left( \pm 2^{\circ} \mathrm{C}\right)$ and $70 \%$ relative humidity $(\mathrm{RH})$. Three replicates were studied for each temperature moisture combination. Plastic pails were used to hold the samples and the samples were placed in mesh bags holding 3 and $5 \mathrm{~kg}$ grain. Sampling for $12 \mathrm{wk}$ was from the $5 \mathrm{~kg}$ bag while two $3 \mathrm{~kg}$ bags on the top and bottom served as a moisture buffer. The arrangement was such that, the bottom of the pail contained about $2 \mathrm{~L}$ of $\mathrm{KOH}$ of known specific gravity to maintain required relative humidities (Solomon 1951), over which was a support to hold the grain sample in the mesh bags. A notable decrease in moisture content of grain over time was observed for rye and canola in previous 16 wk storage studies (Sathya 2006). A buffer of $3 \mathrm{~kg}$ grain bags with the same moisture content as that of the sample maintained moisture levels in the samples. It was hypothesized that moisture loss would occur from buffer grain and not the sample. Sampling was done every week and grain samples were collected from the middle bag, after mixing thoroughly, for quality analysis.

\subsubsection{Sampling frequency}

The moisture content and the germination of the samples were analyzed every week; and invisible mould, FAV and mycotoxin analysis were carried out once every two weeks (even weeks). A representative sample of about $50 \mathrm{~g}$ was collected from each container during odd weeks, and in even weeks about $500 \mathrm{~g}$ of representative sample was collected for analysis. 


\subsection{Grain Quality Assessment}

\subsubsection{Germination}

The change in seed germination over time was tested every week according to the method of Wallace and Sinha (1962). About $10 \mathrm{~g}$ of sub sample was used for the germination test. In a $9 \mathrm{~cm}$ diameter Petri dish, 25 seeds were placed on a Whatman no. 3 filter paper saturated with $5.5 \mathrm{ml}$ of distilled water. The Petri dishes were vertically stacked in a stand; and to prevent dessication of the filter paper the stacked dishes were covered with a polythene bag. This set up was incubated at $25^{\circ} \mathrm{C}$ for $4 \mathrm{~d}$ when the polythene bag was removed and incubation continued for another $3 \mathrm{~d}$. The number of seeds germinated after $7 \mathrm{~d}$ of incubation was counted and the germination (\%) was determined.

\subsubsection{Moisture content}

The moisture content of the samples was expected to remain constant but needed to be monitored during the study. Therefore, every week, the moisture content was determined by placing approximately $10 \mathrm{~g}$ of unground grain in a hot air oven (70 DM (6556/6556), Thermo Electron Corporation, Marietta, $\mathrm{OH}$ ) for $19 \mathrm{~h}$ at $130^{\circ} \mathrm{C} \pm 2^{\circ} \mathrm{C}$ (ASAE 2003). The moisture content of the sample was calculated and expressed in percentage wet basis.

\subsubsection{Visible and invisible mould}

The deterioration of the grain samples was inspected by visual inspection of the samples every week. This method is very subjective but is good enough in indicating advanced deterioration. The presence of invisible mould and the microfloral identification was done every two weeks of storage. For identification of the invisible microfloral species, 25 
seeds were placed in a $9 \mathrm{~cm}$ Petri dish with Whatman no. 3 filter paper saturated with 5.5 $\mathrm{ml}$ of $7.5 \%$ aqueous sodium chloride $(\mathrm{NaCl})$ solution. The Petri dishes were stacked vertically in stands; covered with plastic bags; and incubated at $25^{\circ} \mathrm{C}$ for $4 \mathrm{~d}$. On the fourth day the bag was removed and on the seventh day the microfloral species on the grain were identified using a dissection microscope (Mills et al. 1978).

\subsubsection{Free fatty acids}

The free fatty acid value (FAV) analysis was carried out according to the American Association of Cereal Chemists procedure (AACC 1962) with some modifications. The FAV values were determined by using a Goldfisch fat extractor followed by titration with a KOH solution (Schroth et al. 1998). Before grinding, the samples were dried in hot air oven at $130 \pm 2^{\circ} \mathrm{C}$ for $19 \mathrm{~h}$. A Stein mill (M-2, Fred Stein Laboratories, Inc, Atchinson, $\mathrm{KS}$ ) was used to grind the samples; $5 \mathrm{~g}$ of ground wheat sample was placed and folded in a Whatman no. 5 filter paper. This was placed inside a glass thimble/cylinder and was attached to the fat extractor (Goldfisch Fat Extractor, Laboratory Construction Co, Kansas City, MO) with $30 \mathrm{~mL}$ of petroleum ether solvent in beakers. The solvent was heated and allowed to condense, and pass through the same sample for $6 \mathrm{~h}$ continuously. The oil was separated from the solvent by heating it again and $25 \mathrm{~mL}$ of TAP solution (50\% toluene and $50 \%$ ethanol with phenolphthalein indicator) was added to the oil. A $\mathrm{KOH}$ solution of known normality was used for titration until the appearance of a pale pink color; and the FAV value was expressed as $\mathrm{mg} \mathrm{KOH} / 100 \mathrm{~g}$ of dry grain. 


\subsection{Ochratoxin Analysis}

Determination of ochratoxin in durum wheat by HPLC with fluorescence detection.

\subsubsection{Sample preparation}

About $500 \mathrm{~g}$ of wheat samples were stored in a freezer for ochratoxin analysis. A subsample of about $50 \mathrm{~g}$ was separated with a sample divider. The sample was ground using a benchtop coffee grinder and mixed well.

\subsubsection{Extraction and Centrifugation}

In a $250 \mathrm{~mL}$ Teflon centrifuge tube, $30 \mathrm{~g}$ of ground sample with $5 \mathrm{~g}$ of Celite, $25 \mathrm{~mL}$ of $0.1 \mathrm{M} \mathrm{H}_{3} \mathrm{PO}_{4}$ and $150 \mathrm{~mL}$ of chloroform were shaken for $45 \mathrm{~min}$ on a flatbed shaker at 280 excursions per minute. Then the bottles were left in a freezer for $10 \mathrm{~min}$ before centrifugation. The centrifuge was run at $4^{\circ} \mathrm{C}$, and at a rotor speed of $3000 \mathrm{rpm}$ on low brake for $10 \mathrm{~min}$. The organic layer was filtered through a $2 \mathrm{~V}$ folded filter paper in a 6 $\mathrm{cm}$ funnel. From the filtrate, $25 \mathrm{~mL}$ was rinsed through chloroform 3 times and then transferred into an Erlenmeyer flask. Sep-Pak cleanup was done to separate the ochratoxin fraction and the fraction was dried under nitrogen at $50^{\circ} \mathrm{C}$ to which $1 \mathrm{~mL}$ of acetonirile was added and vortexed for $1 \mathrm{~min}$. To this $1 \mathrm{~mL}$ of $0.5 \%$ acetic acid was added, vortexed for $1 \mathrm{~min}$ and was placed in a sonicator for $15 \mathrm{~min}$. This sample was centrifuged at $4^{\circ} \mathrm{C}$ for $10 \mathrm{~min}$ at $3000 \mathrm{rpm}$ and filtered through a LC13 PVDF $0.45 \mu \mathrm{m}$.

\subsubsection{HPLC analysis (Roscoe 2004)}

Column $3.9 \times 150 \mathrm{~mm}$ Symmetry C18 $5 \mu \mathrm{m}$ steel cartridge column and a Sentry Symmetry column from Waters at a temperature of $30^{\circ} \mathrm{C}$ at a flow rate of $0.9 \mathrm{~mL} / \mathrm{min}$. 


\section{Gradient conditions}

\begin{tabular}{cccll}
\hline Time (min) & $\mathrm{A} \%$ & $\mathrm{~B} \%$ & & A - Milli-Q water $\mathrm{pH} 3.3$ with acetic acid \\
\cline { 1 - 3 } Int. & 70 & 30 & & B - Acetonitrile \\
2 & 70 & 30 & \\
10 & 40 & 60 & \\
18 & 40 & 60 & \\
20 & 70 & 30 & \\
30 & 70 & 30 & \\
\hline
\end{tabular}

\section{Wavelengths}

\begin{tabular}{ccc}
\hline Time (min) & Excitation $(\mathrm{nm})$ & Emission $(\mathrm{nm})$ \\
\hline Int. & 310 & 470 \\
10.4 & 280 & 465 \\
11.9 & 340 & 465 \\
30 & 310 & 470 \\
\hline
\end{tabular}

Injection volume $\quad-25 \mu \mathrm{L}$

Detector parameters - (a) Gain 100

(b) Filter $-1.5 \mathrm{~s}$

(c) Cell volume $16 \mu \mathrm{L}$

Retention times - (a) Ochratoxin B - 10.0 min

(b) Ochratoxin A - $12.7 \mathrm{~min}$

Calculation of analyte in $\mathrm{ppb}=\mathrm{A} / \mathrm{A}^{1} \times \mathrm{C} / \mathrm{W} \times \mathrm{F}$.V.
A - Area of parameter in sample
$\mathrm{A}^{1} \quad$ - Area of parameter in standard
C - Concentration of parameter in standard $(\mathrm{ng} / \mu \mathrm{L})$
W - Weight of sample used $\times \mathrm{mL}$ of extract used $/ \mathrm{mL}$ of solvent added
F.V. - Final value of extract 


\subsection{Statistical Analysis}

Analysis of variance (ANOVA) of a three factorial model (6 moisture contents $(15,16$, $17,18,19$ and $20 \%$ m.c. $) \times 4$ temperatures $\left(10,20,30\right.$ and $\left.40^{\circ} \mathrm{C}\right) \times 12$ weeks $)$ was used to analyze the effects of temperature, storage period and moisture content on the germination and FAV of the samples by using SAS 9.1.3 (Statistical Analysis Systems Institute, Inc., Cary, NC, USA). Comparison of means was done by the least significant difference (LSD) method to compare the changes in germination and FAV over storage time. 


\section{RESULTS AND DISCUSSION}

\subsection{Germination}

The germination of stored wheat was used as an indicator of deterioration of grain during storage as germination is more sensitive to quality changes. Germination is the first factor that gets affected due to poor storage conditions and also storing dead seeds is not easy. Figure 3 shows the changes in germination of durum wheat at four different temperatures: $10,20,30$ and $40^{\circ} \mathrm{C}$, for different moisture contents. The initial germination of durum wheat was around $91 \%$ for all the moisture content samples. All the samples stored at the lowest temperature of $10^{\circ} \mathrm{C}$, and even the high moisture samples $(15-18 \%)$ did not lose their viability throughout the storage period of 12 weeks; however at $40^{\circ} \mathrm{C}$, germination reached zero in a few weeks from the start of the study. The changes in germination at 20 and $30^{\circ} \mathrm{C}$ were in between these two conditions (Fig. 3).

For the samples stored at $10^{\circ} \mathrm{C}$, only the high moisture grain, 19 and $20 \%$ m.c. showed a continuous decline in germination reaching around 16 and $12 \%$, respectively after 12 weeks. But the germination of wheat at 15,16 and $17 \%$, stayed around $80 \%$ of the initial germination throughout the storage period. The 15 and $16 \%$ m.c. samples had a germination of $89 \%$ after 12 weeks, and $17 \%$ m.c. samples had a germination of $74 \%$. The germination of $18 \%$ m.c. samples was almost similar to that of $17 \%$ m.c. samples and had a final germination of $66 \%$ after 12 weeks.

The samples stored at $20^{\circ} \mathrm{C}, 20 \%$ m.c. wheat had germination decrease throughout the experiment, with the lowest being $5 \%$ at the $12^{\text {th }}$ week. The 15 and $16 \%$ m.c. samples 
followed similar trends for germination and had 77 and $64 \%$ of germination decrease after 12 weeks. The samples with 17,18 and $19 \%$ m.c. had a similar trend in germination decline and had 29,30 and $24 \%$ germination at the end of the study.

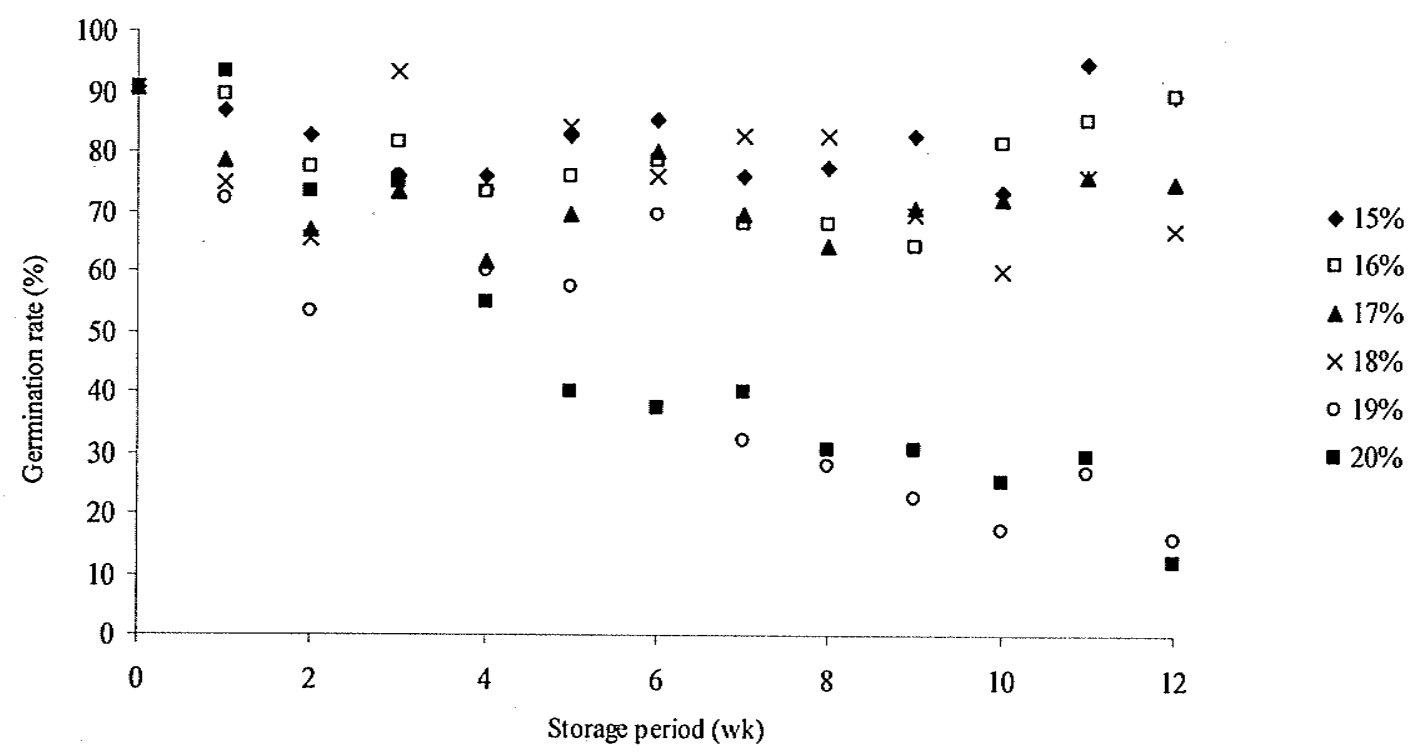

(a)

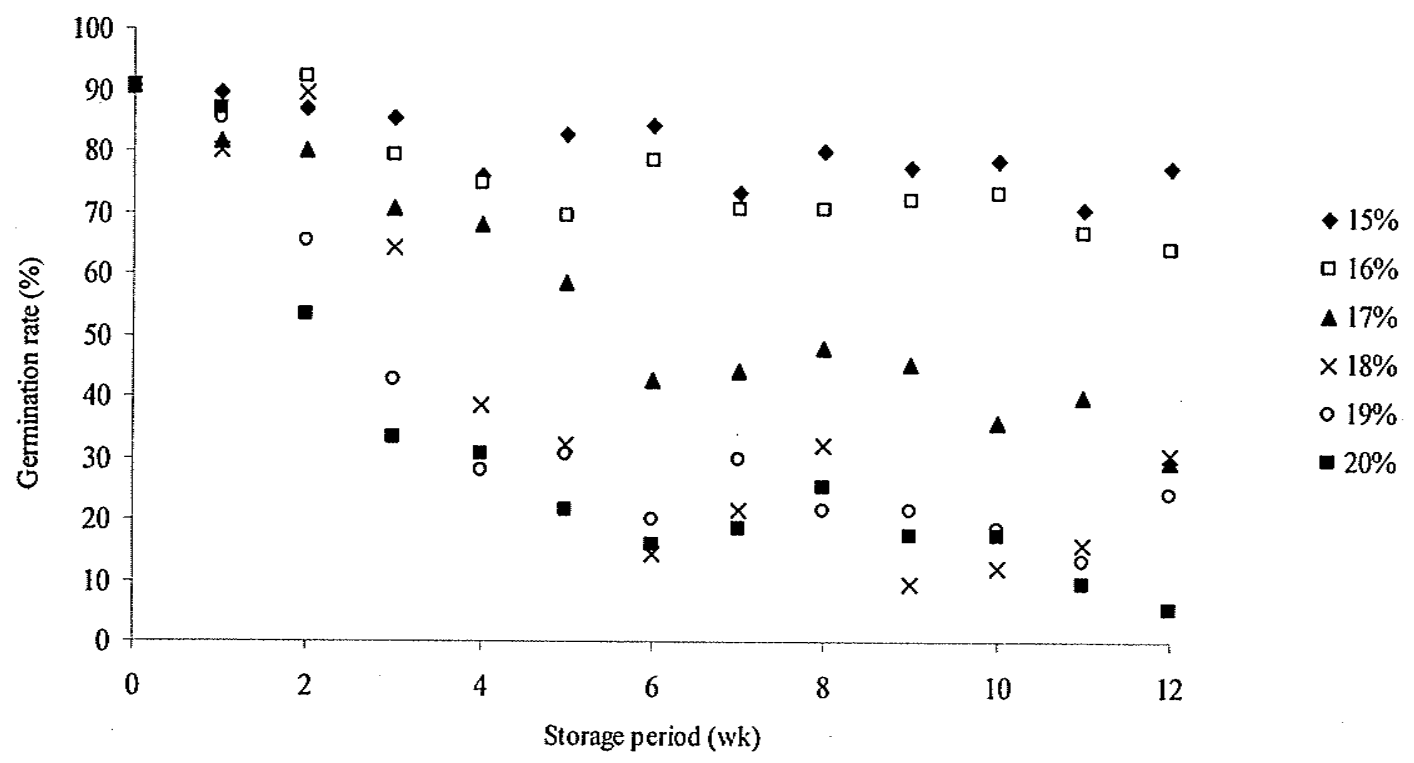

(b) 


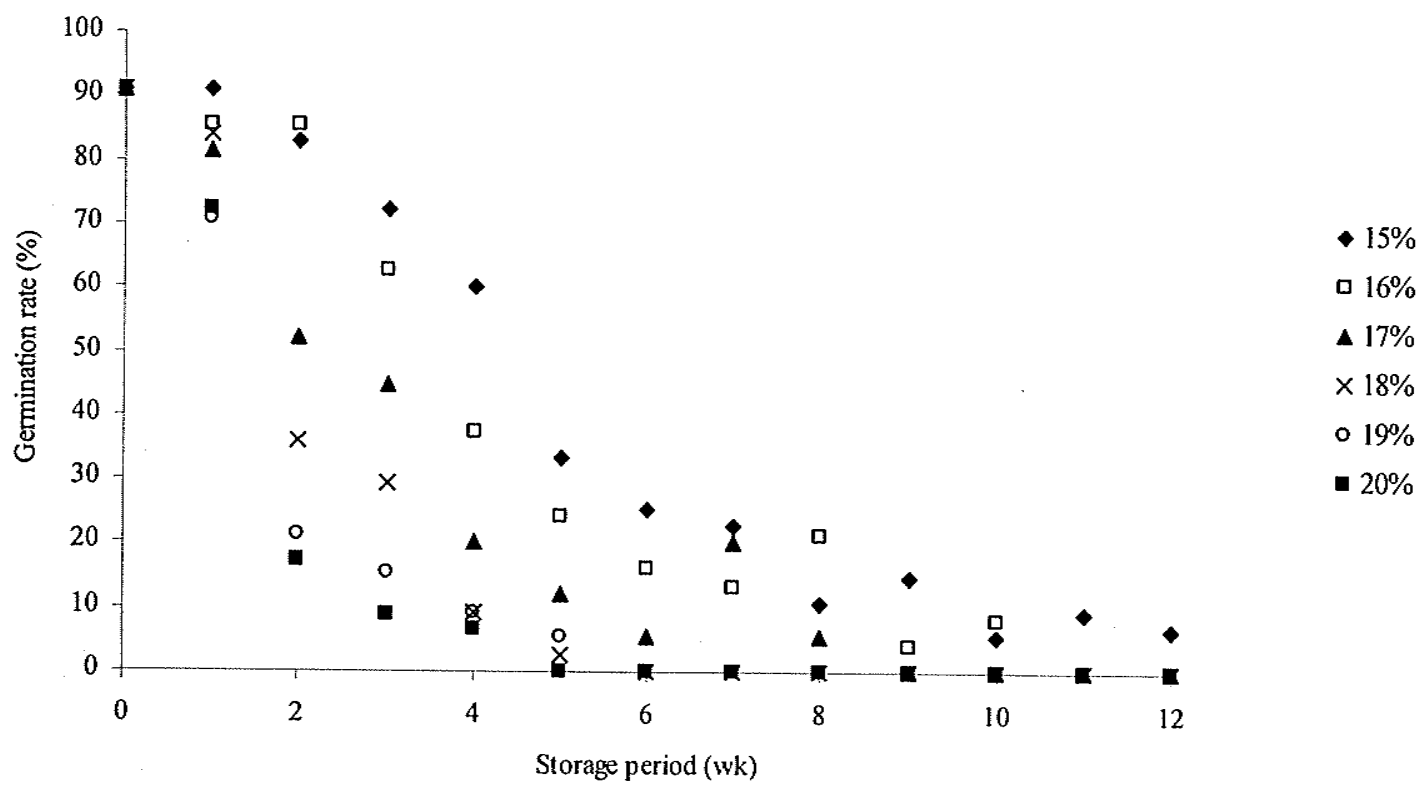

(c)

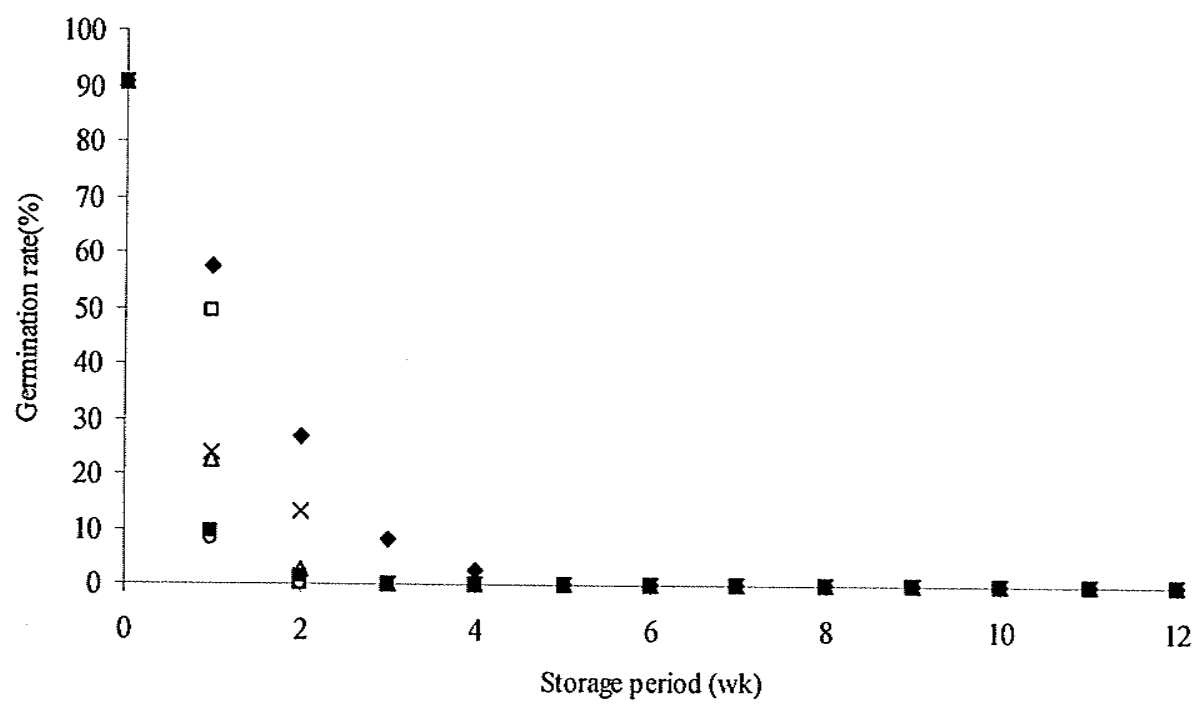

(d)

Fig. 3. Changes in germination of durum wheat with storage period at (a) $10^{\circ} \mathrm{C}$ (b) $20^{\circ} \mathrm{C}$ (c) $30^{\circ} \mathrm{C}$ (d) $40^{\circ} \mathrm{C}$ 
The germination of samples stored at the higher temperatures of 30 and $40^{\circ} \mathrm{C}$ reached zero well before the end of the study. At $30^{\circ} \mathrm{C}$, only the $15 \%$ m.c. samples had some germination of $6 \%$ until the end of the study. All other moisture samples reached zero at some point during the storage. The 16 and $17 \%$ m.c. samples lost all germination at 8 and $10^{\text {th }}$ week, respectively. The 18 and $19 \%$ m.c. samples followed similar trends and reached $0 \%$ germination at the end of the $5^{\text {th }}$ week, and the $20 \%$ m.c. samples reached a germination of $0 \%$ at the end of the $4^{\text {th }}$ week.

At $40^{\circ} \mathrm{C}$, the 18,19 and $20 \%$ m.c. samples had a significant decrease in germination after a week of storage and reached around $20 \%$ germination. Almost all moisture samples had similar germination decline trends and reached $0 \%$ germination before 6 weeks of storage. The $15 \%$ m.c. samples reached $0 \%$ germination after 4 weeks of storage whereas, $16,17,18,19$, and $20 \%$ m.c. samples reached $0 \%$ germination after 2 weeks.

According to Pomeranz (1992), germination is the most important factor to assess the quality of grain during storage. The effect of storage parameters like moisture content, temperature and storage time had significant effects $(\alpha=0.05)$ on the germination. The germination data and the least significant difference (LSD) of means of germination are given in Appendix A. The germination dropped with increasing time, temperature and moisture content. This correlates with the results of Christensen and Kauffmann (1969) who reported that increased storage temperatures cause injury or death to most types of grain. The grain samples with low moisture content were susceptible to spoilage at higher 
temperatures of 30 and $40^{\circ} \mathrm{C}$. Wallace and Sinha (1962) reported that there exists a negative correlation between germinability and storage temperature.

\subsection{Moisture Content}

The moisture content of the samples was expected to remain constant over the storage time. To maintain the initial moisture content of the samples throughout the study, KOH solutions of different specific gravities for each moisture content were used (Solomon 1951). The moisture content of the samples remained generally constant throughout the study except for a few weeks (Fig.4). At 10,30 and $40^{\circ} \mathrm{C}$, the moisture content of the samples was constant for 3 weeks and had a slight decrease in the following 3 weeks (until the $6^{\text {th }}$ week). After 6 weeks, the moisture increased to the original level and maintained until the $12^{\text {th }}$ week. Conversely, at $20^{\circ} \mathrm{C}$ the moisture remained constant for 5 weeks, and then increased in the $6^{\text {th }}$ week and again regained its original level after the $7^{\text {th }}$ week, and maintained the same level throughout the end of the study. The moisture content data are given in Appendix B. 


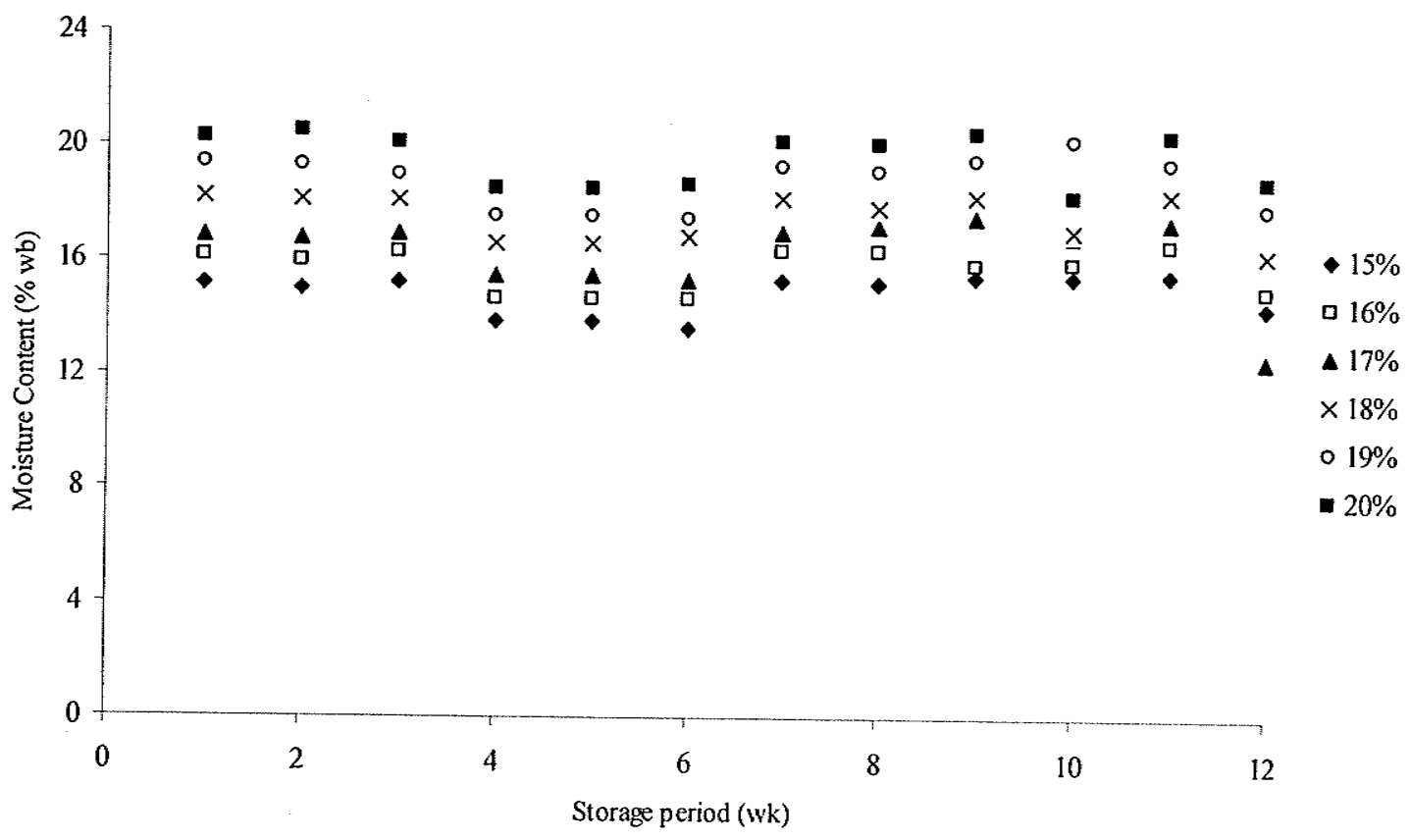

(a)

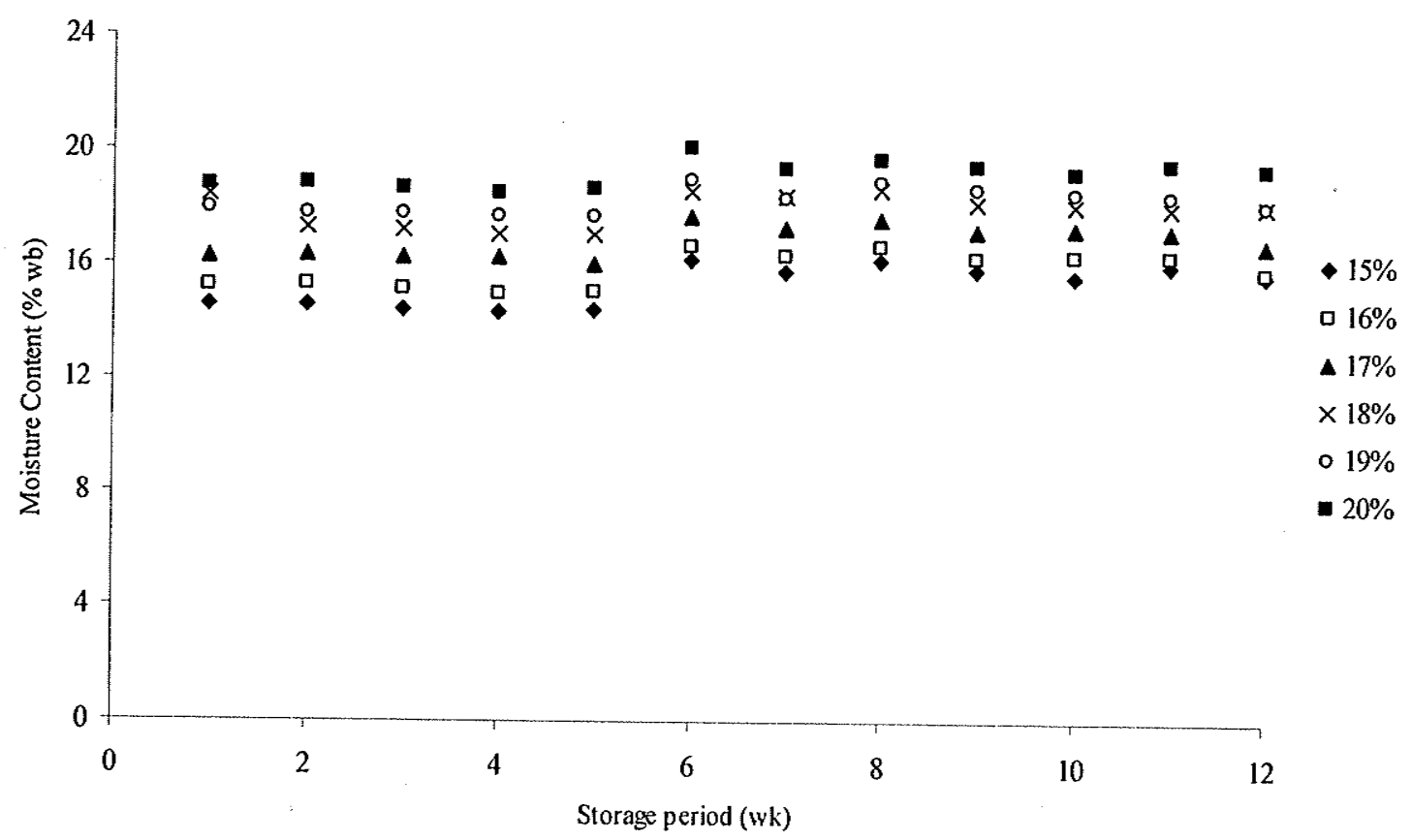

(b) 


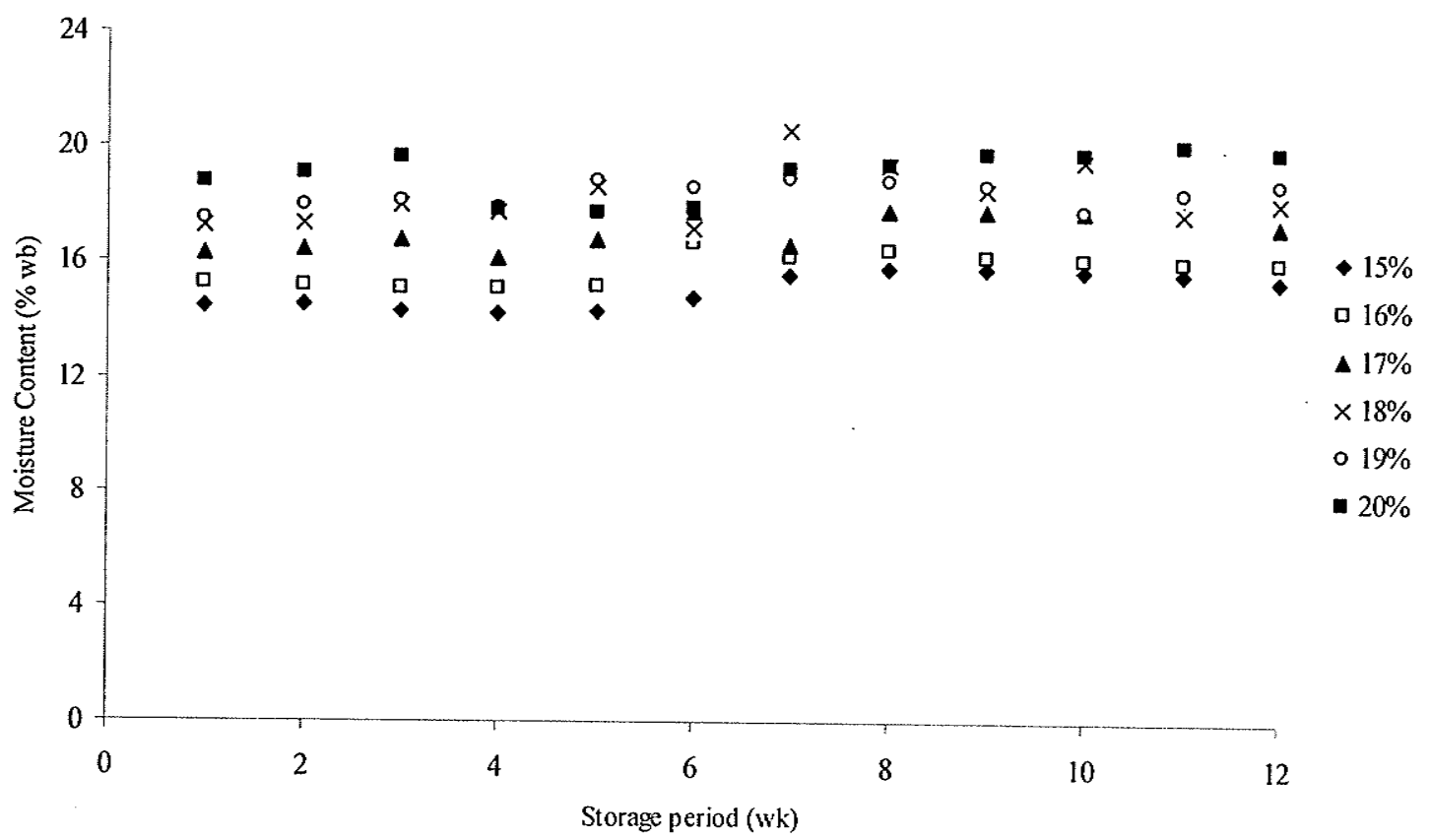

(c)

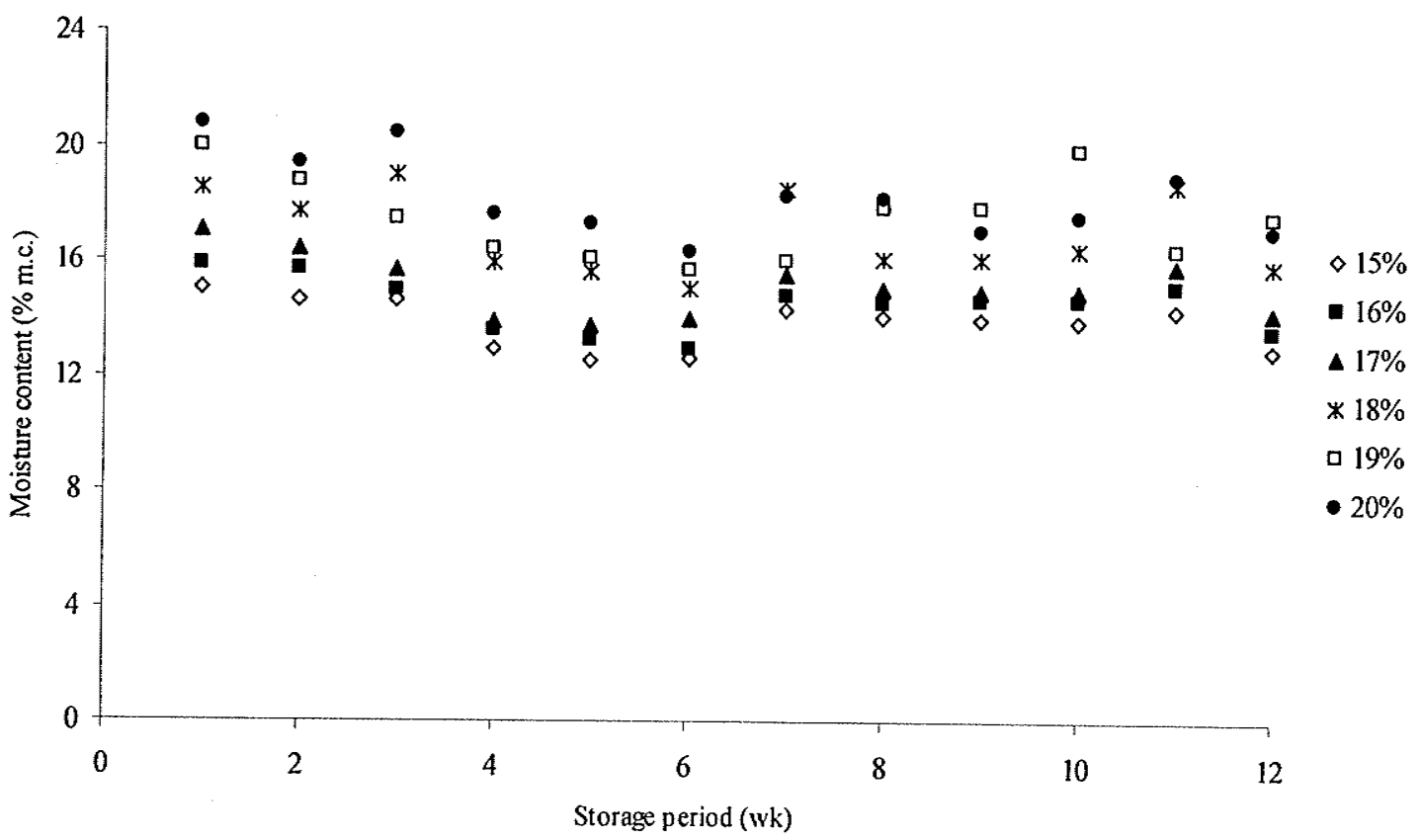

(d)

Fig. 4. Changes in moisture content of durum with storage period at

(a) $10^{\circ} \mathrm{C}$ (b) $20^{\circ} \mathrm{C}$ (c) $30^{\circ} \mathrm{C}$ (d) $40^{\circ} \mathrm{C}$ 


\subsection{Microflora}

The presence of visible mould in grain during storage is always used as an index of deterioration. The appearance of visible mould and the respective germination of the durum samples is given in Table 4. Increase in both the temperature and moisture content had greater effects on the growth of fungi and presence of visible mould. Visible mould appeared in all high moisture samples irrespective of the temperature.

Table 4. Time of first appearance of visible mould (wk) and respective germination (\%) (value after,) of durum wheat

\begin{tabular}{|c|c|c|c|c|c|c|c|}
\hline \multicolumn{2}{|c|}{$\begin{array}{l}\text { Initial moisture content } \\
(\% \mathrm{wb})\end{array}$} & 15 & 16 & 17 & 18 & 19 & 20 \\
\hline $\begin{array}{l}\text { Temperature } \\
\left({ }^{\circ} \mathrm{C}\right)\end{array}$ & Replicate & & & & & & \\
\hline \multirow[t]{3}{*}{10} & $\mathrm{a}$ & - & - & 10,56 & 8,88 & 7,36 & 7,44 \\
\hline & $\mathrm{b}$ & - & - & 10,88 & 8,88 & 7,44 & 7,28 \\
\hline & $\mathrm{c}$ & $\begin{array}{l}- \\
-\end{array}$ & - & 10,72 & 8,72 & 7,16 & 7,48 \\
\hline \multirow[t]{3}{*}{20} & a & - & _- & 5,68 & 3,62 & 2,64 & 2,52 \\
\hline & b & - & - & 5,60 & 3,70 & 2,60 & 2,48 \\
\hline & $\mathrm{c}$ & - & - & 5,48 & 3,60 & 2,72 & 2,60 \\
\hline \multirow[t]{3}{*}{30} & a & 5,16 & 3,64 & 2,56 & 2,36 & 2,20 & 1,80 \\
\hline & b & 5,52 & 3,60 & 2,44 & 2,44 & 2,20 & 1,72 \\
\hline & c & 5,32 & 3,64 & 2,56 & 2,28 & 2,24 & 1,64 \\
\hline \multirow[t]{3}{*}{40} & $\mathrm{a}$ & 8,0 & 2,0 & 1,32 & 1,20 & 1,4 & 1,12 \\
\hline & $\mathrm{b}$ & 8,0 & 2,0 & 1,20 & 1,28 & 1,12 & 1,8 \\
\hline & $\mathrm{c}$ & 8,0 & 2,0 & 1,16 & 1,24 & 1,8 & 1,8 \\
\hline
\end{tabular}

The 15 and $16 \%$ m.c. samples at both 10 and $20^{\circ} \mathrm{C}$ did not show any presence of visible mould throughout the study, and $17 \%$ m.c. samples were the first to show appearance of visible mould irrespective of temperature. At $10^{\circ} \mathrm{C}$, the presence of visible mould was noticed at the end of 10, and 8 weeks for 17 and $18 \%$ m.c. samples, and 19 and $20 \%$ m.c. 
samples showed the appearance of visible mould by the end of $7^{\text {th }}$ week. The samples stored at $20^{\circ} \mathrm{C}$ had visible mould as early as the $5^{\text {th }}$ week at $17 \%$ m.c. Right from the start of the experiment (week 1), the samples with $17,18,19$ and $20 \%$ m.c. stored at $40^{\circ} \mathrm{C}$ had visible mould. The samples stored at $40^{\circ} \mathrm{C}$ with $16 \%$ m.c., $30^{\circ} \mathrm{C}$ with $17,18,19$ and $20 \%$ m.c., and $20^{\circ} \mathrm{C}$ with 19 and $20 \%$ m.c. showed visible mould by the end of week 2 . At $40^{\circ} \mathrm{C}$, even samples with $15 \%$ m.c. showed visible mould after 8 weeks of storage. Moisture content of the sample is very critical for the development of visible mould. Even at high temperatures, the low moisture samples were devoid of visible mould.

Penicillium spp. and A. glaucus group were the most predominant fungal species in all samples at the beginning of the storage. At cooler temperatures Penicillium spp. thrived and $A$. glaucus preferred higher temperatures. Both these groups dominated during the later weeks of storage except at $40^{\circ} \mathrm{C}$. The appearance of bacteria was seen only at cooler temperatures and as the temperature increased no bacteria was observed; and at $40^{\circ} \mathrm{C}$ there were no bacteria in any of the samples. Aspergillus. ochraceous was scarcely found in all samples irrespective of temperature, moisture and storage period. Alternaria was found in many samples stored at $10^{\circ} \mathrm{C}$, and high moisture samples stored at high temperatures. Aspergillus niger, A. versicolor and Fusarium were found in some samples but they could not be related with moisture or temperature of the sample. At $40^{\circ} \mathrm{C}$, the amount of microflora was low for all samples, in particular for the high moisture samples. These results support the conclusion of Christensen and Kaufmann (1969) that storing grain at moderate temperatures even with high moisture content will be safe without any invasion of fungi. The microflora data are given in Appendix C. 


\subsection{Fatty Acid Values}

The enzymatic secretion by the microorganisms in grain breaks down the lipids by hydrolysis which results in the production of free fatty acids. Storage of high moisture grain results in excessive fungal growth which induces drastic chemical changes proportional to the moisture level. The initial fatty acid value (FAV) of the sample was $5.1 \mathrm{mg} \mathrm{KOH} / 100 \mathrm{~g}$ of dry grain; and it was found to increase with moisture content, storage temperature, and time (Fig. 5.). The fatty acid values did not follow any regular trend at all temperatures. The FAV of the samples stored at $10^{\circ} \mathrm{C}$, had a sharp increase untill the end of thè $6^{\text {th }}$ week. By the $8^{\text {th }}$ week, FAV had a sudden drop which then increased untill the end of the study. The $15 \%$ m.c. samples had the highest FAV of 45 $\mathrm{mg} \mathrm{KOH} / 100 \mathrm{~g}$ of dry grain in the $6^{\text {th }}$ week. The highest FAV of the samples stored at $10^{\circ} \mathrm{C}$ was $79 \mathrm{mg} \mathrm{KOH} / 100 \mathrm{~g}$ of dry grain for $20 \% \mathrm{~m} . \mathrm{c}$. at the end of $12^{\text {th }}$ week.

The same trend of changes in FAV as for the samples at $10^{\circ} \mathrm{C}$ was followed by the samples stored at $20^{\circ} \mathrm{C}$. FAV increased until 4 weeks, then decreased by the $6^{\text {th }}$ week, and then reached a peak value after 8 weeks and had some decrease for the rest of the storage period for the samples at $17,18,19$ and $20 \%$ m.c. The samples stored at 15 and $16 \%$ m.c. did not increase after 6 weeks but showed a decrease in value. The values were similar and followed a similar trend in change in FAV. The FAV was low compared to other temperature and moisture samples, and were near $10 \mathrm{mg} \mathrm{KOH} / 100 \mathrm{~g}$ of dry grain throughout the study for 15 and $16 \%$ m.c. samples. The $18 \%$ m.c. sample after 8 weeks of storage had the highest FAV of $40 \mathrm{mg} \mathrm{KOH} / 100 \mathrm{~g}$ of dry grain. 


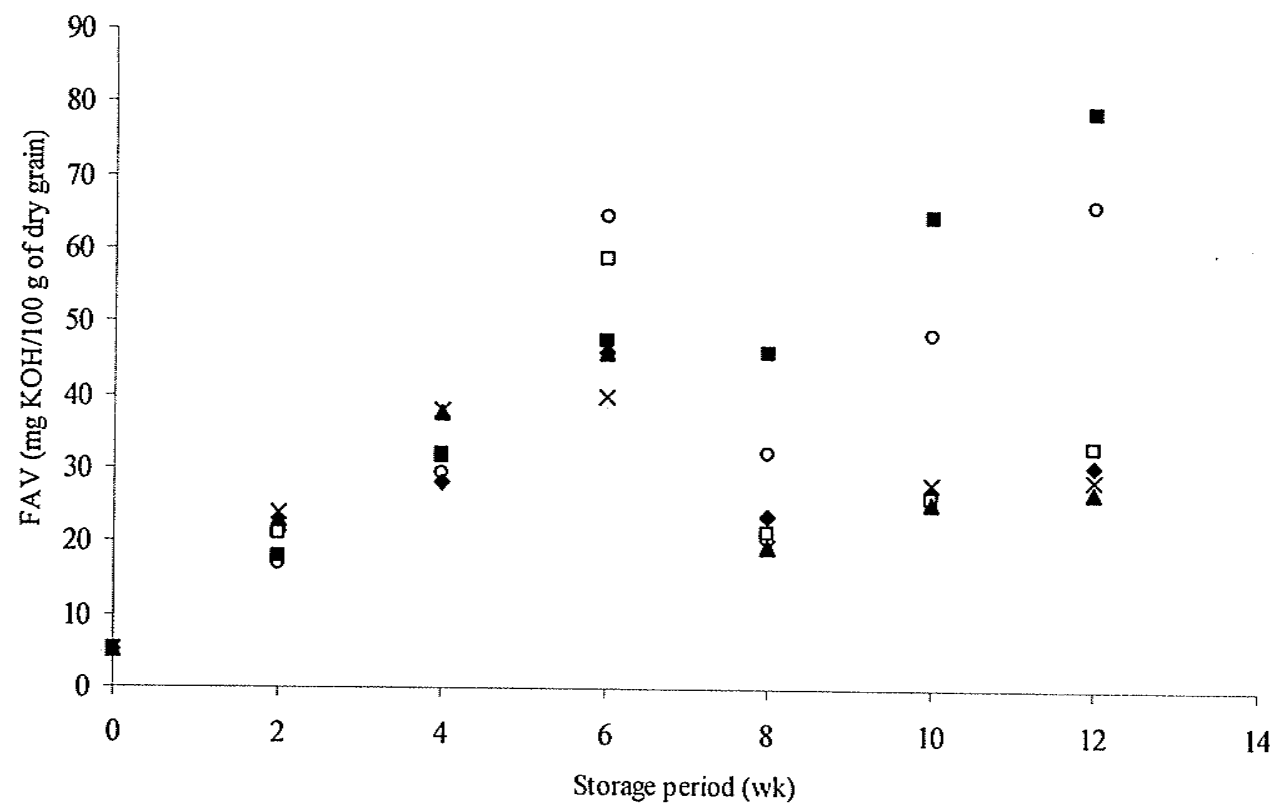

- $15 \%$

ㅁ $16 \%$

- $17 \%$

$\times 18 \%$

- $19 \%$

- $20 \%$

(a)

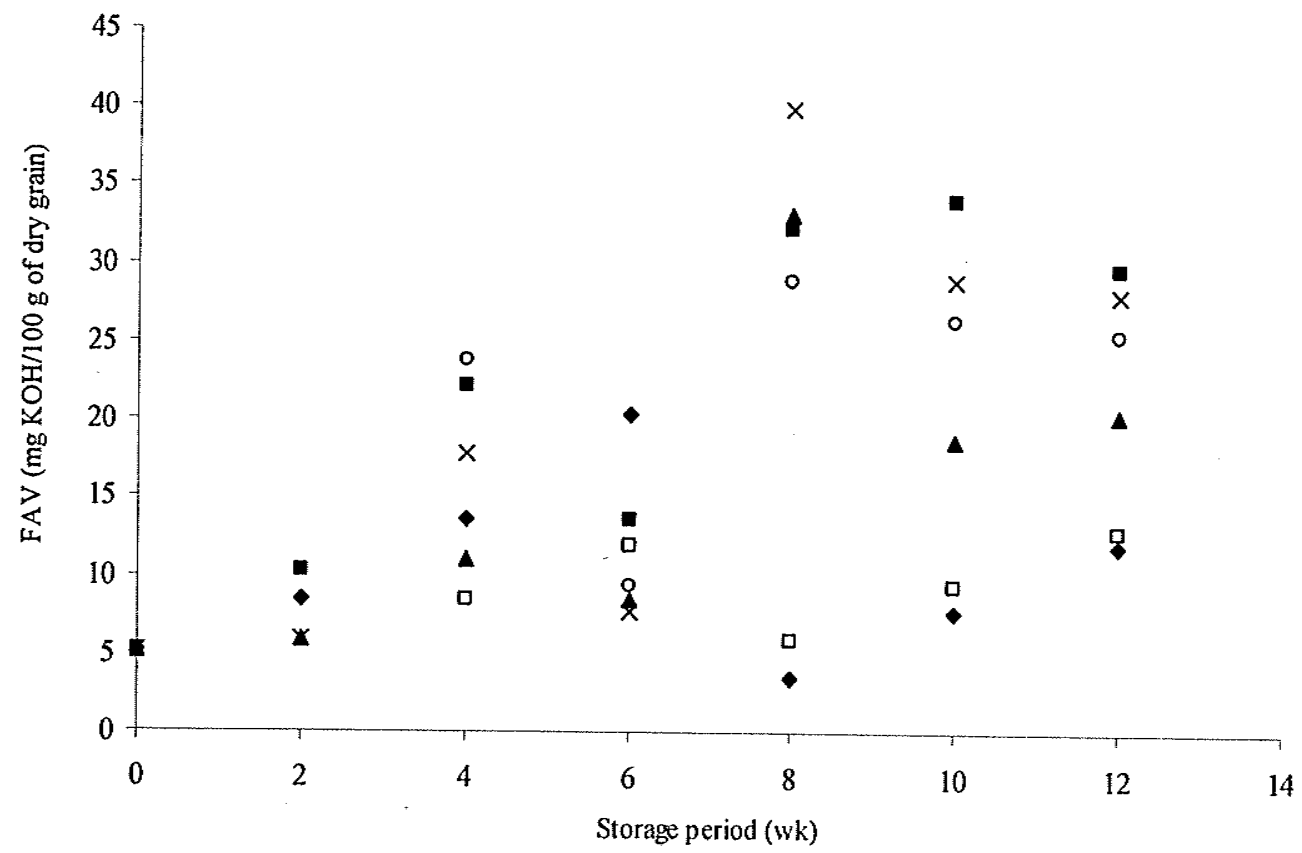

$+15 \%$

ㅁ $16 \%$

- $17 \%$

$\times 18 \%$

- $19 \%$

- $20 \%$

(b) 


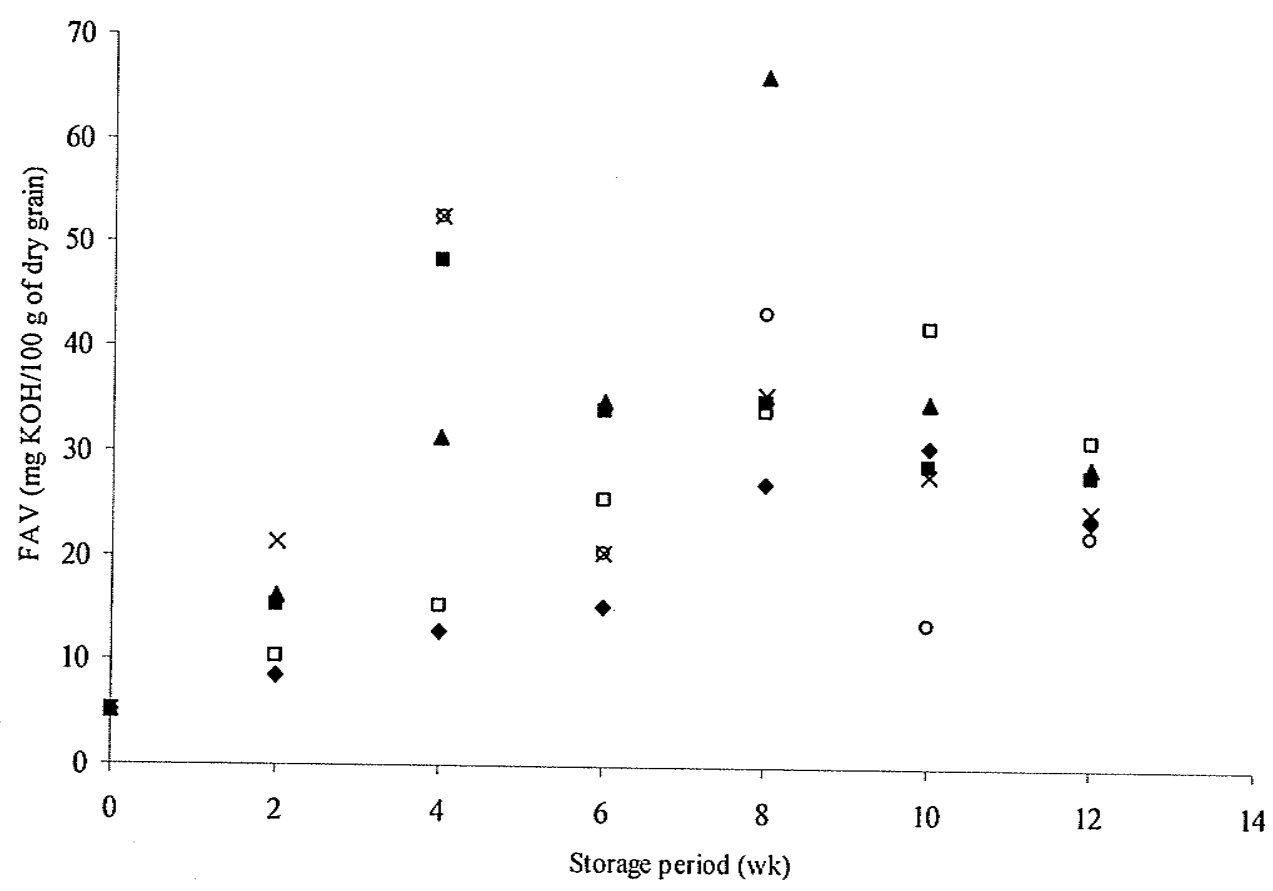

- $15 \%$

$16 \%$

A $17 \%$

$\times 18 \%$

$\circ 19 \%$

- $20 \%$

(c)

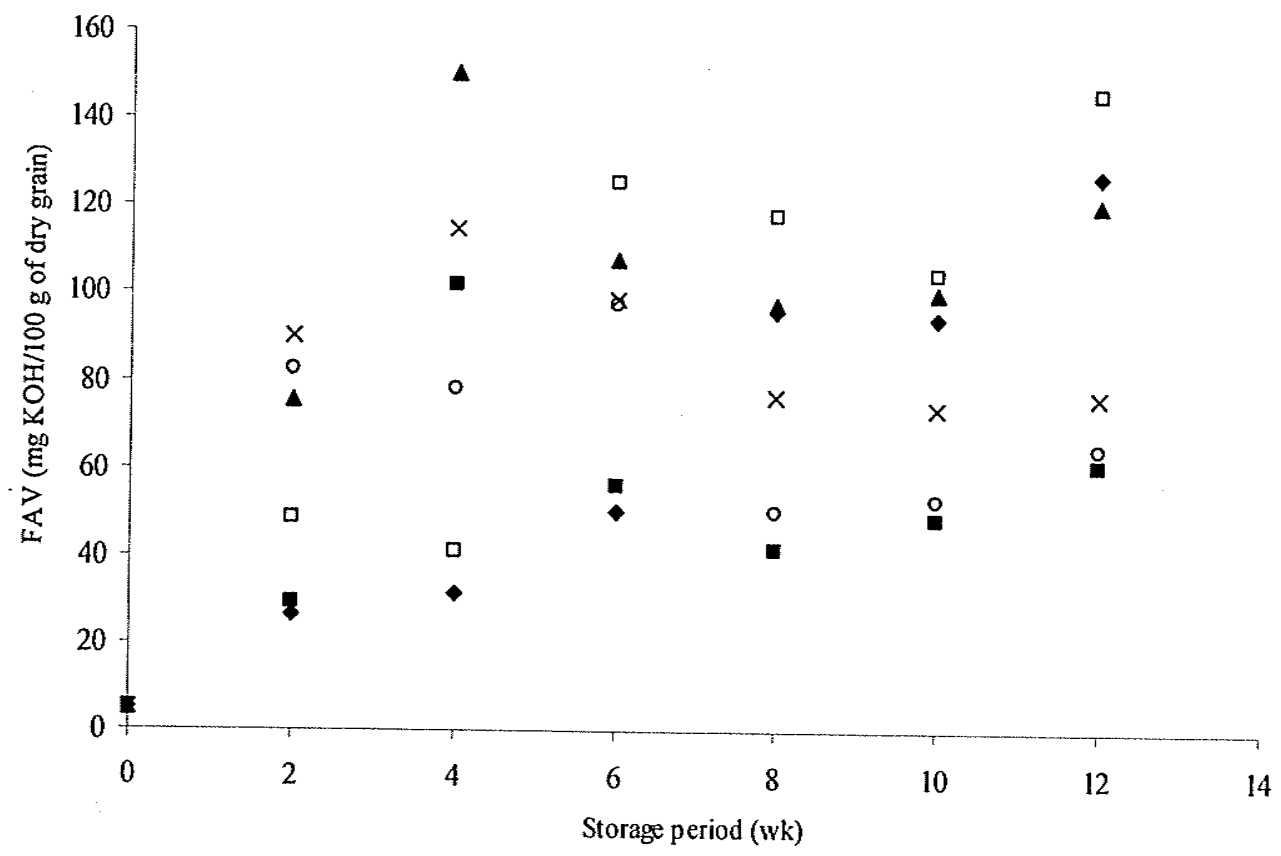

- $15 \%$

$16 \%$

$\Delta 17 \%$

$\times 18 \%$

- $19 \%$

- $20 \%$

(d)

Fig. 5. Changes in FAV of durum wheat with respect to time at

(a) $10^{\circ} \mathrm{C}$ (b) $20^{\circ} \mathrm{C}$ (c) $30^{\circ} \mathrm{C}$ (d) $40^{\circ} \mathrm{C}$ 
The samples stored at $30^{\circ} \mathrm{C}$ had a gradual increase in FAV for 8 weeks and then showed a small decrease in value by the end of 12 weeks. The high moisture samples $(18,19$ and $20 \%$ m.c.) had an increase in FAV by the end of 4 weeks and then followed a similar trend as the other samples. The highest FAV of $66 \mathrm{mg} \mathrm{KOH} / 100 \mathrm{~g}$ of dry grain at the end of 8 weeks was obtained for $17 \%$ m.c., however, by the end of 12 weeks the FAV had decreased to $28 \mathrm{mg} \mathrm{KOH} / 100 \mathrm{~g}$ of dry grain. All the samples showed almost similar values or trends of FAV after 8 weeks of storage irrespective of the moisture content.

The samples stored at $40^{\circ} \mathrm{C}$ behaved differently with respect to the moisture content of the samples. The high moisture content samples and the low moisture samples had a distinct trend for FAV. The high moisture samples $(18,19$ and 20\% m.c.) had lower FAV than the low moisture samples $(15,16$ and $17 \%$ m.c.) at the end of 12 weeks. The high moisture samples had a dramatic increase in FAV at the start of the study but at the end, the FAV was lowered compared to the other samples. The FAV of 18,19 and $20 \%$ m.c. samples at the end of 12 weeks was 76,64 and $61 \mathrm{mg} \mathrm{KOH} / 100 \mathrm{~g}$ of dry grain against 127,146 and $120 \mathrm{mg} \mathrm{KOH} / 100 \mathrm{~g}$ of dry grain of FAV for 15,16 and $17 \%$ m.c. samples after 12 weeks of storage. These results correlate with the conclusion of Wallace et al. (1983) who confirmed that there exists a positive correlation between FAV and moisture; with a negative correlative between FAV and temperature. The storage period and moisture content of the grain were found to have a significant effect $(\alpha=0.05)$ on the FAV values and there was an increase in the FAV values with increase in moisture content and storage time. Similar results were obtained for rye and canola (Sathya 2006); and for oats 
and barley (White et al. 1999). Data and the least significant difference (LSD) of means of FAV are given in Appendix D.

\subsection{Ochratoxin}

Ochratoxin is the most common and most toxic contaminant in cereal grains. The level of ochratoxin was quantified from the samples collected every 2 weeks. The ochratoxin detectable limit was $10 \mathrm{ppb}$, and if the samples did not show any presence of ochratoxin they were reported to have $<10 \mathrm{ppb}$ ochratoxin. Penicillium verrucosum was found to be the only producer of ochratoxin in cereal grains, in temperate countries (Ciegler et al. 1973 and Frisvad and Lund 1993). They concluded that if $P$. verrucosum infestation is greater than $7 \%$, then ochratoxin will be produced in cereal grain. Hence isolation of $P$. verrucosum was done before analyzing the samples for ochratoxin. Only the samples with high infestation were further analyzed. The samples stored at 30 and $40^{\circ} \mathrm{C}$ did not show any presence of $P$. verrucosum and so they were not analyzed for ochratoxin.

However, the samples stored at 10 and $20^{\circ} \mathrm{C}$ showed higher incidence of $P$. verrucosum and were analyzed for ochratoxin. Initially the analysis was started for the $12^{\text {th }}$ week samples descending down to week 2 . For the samples stored at $10^{\circ} \mathrm{C}$, the amount of ochratoxin present is given in Table 5. As ochratoxin was found in $12^{\text {th }}$ week samples, the $10^{\text {th }}$ week samples were also analyzed. Further analysis for $8^{\text {th }}$ week and other samples will be done later. 
Table 5. Ochratoxin in durum wheat stored at $10^{\circ} \mathrm{C}$ (Replicate 1)

\begin{tabular}{cccccccc}
\hline $\begin{array}{c}\text { Storage } \\
\text { Period } \\
(\mathrm{wk})\end{array}$ & $\begin{array}{c}\text { Mycotoxin } \\
(\mathrm{ppb})\end{array}$ & 15 & 16 & 17 & 18 & 19 & 20 \\
\hline 10 & OTA & $<10$ & $\operatorname{tr}$ & $<10$ & $\operatorname{tr}$ & 110 & 400 \\
& OTB & $<10$ & $<10$ & $<10$ & $<10$ & $\operatorname{tr}$ & 23 \\
& Zearalenone & $<100$ & $<100$ & $<100$ & $<100$ & $<100$ & $<100$ \\
& & & & & & \\
12 & OTA & $<10$ & $<10$ & $<10$ & $<10$ & 68 & 76 \\
& OTB & $<10$ & $<10$ & $<10$ & $<10$ & $<10$ & $<10$ \\
& Zearalenone & $<100$ & $<100$ & $<100$ & $<100$ & $<100$ & $<100$ \\
\hline
\end{tabular}

For the samples stored at $10^{\circ} \mathrm{C}$, zearalenone was not detected throughout the study. Ochratoxin B was found only in the $20 \%$ m.c. sample after 10 weeks of storage, but they were not present in the $12^{\text {th }}$ week samples. Ochratoxin A was found only in high moisture samples of 19 and $20 \%$ m.c. At $20^{\circ} \mathrm{C}$, only the $12^{\text {th }}$ week samples were analyzed for ochratoxin (Table 6). Ochratoxin A was present for the samples with $20 \%$ m.c. Ochratoxin analysis for other moisture contents for $12^{\text {th }}$ week samples will be done later.

Table 6. Ochratoxin in durum wheat stored at $20^{\circ} \mathrm{C}$ after 12 weeks

\begin{tabular}{|c|c|c|c|c|c|c|c|}
\hline \multirow{2}{*}{$\begin{array}{c}\text { Mycotoxin } \\
\text { (ppb) }\end{array}$} & \multirow{2}{*}{ Replicate } & \multicolumn{6}{|c|}{ Moisture Content (\% wb) } \\
\hline & & 15 & 16 & 17 & 18 & 19 & 20 \\
\hline \multirow[t]{3}{*}{ OTA } & 1 & $*$ & $*$ & $*$ & $*$ & * & 192 \\
\hline & 2 & $*$ & $*$ & $*$ & * & * & 154 \\
\hline & 3 & $*$ & $*$ & * & $*$ & * & 135 \\
\hline
\end{tabular}

(* Analysis to be done later). 


\subsection{Estimated safe storage life of durum wheat}

Figure 6 gives the estimated safe storage time of durum wheat obtained from the measured quality parameters. Germination decrease to less than $80 \%$ of initial germination and appearance of visible mould were used for defining the safe storage period. The time (number of weeks) available for the post harvest treatments before the start of deterioration of stored grain, at a particular moisture and temperature for durum wheat can be easily determined. The available time was shown to decrease with increase in moisture content and temperature of the grain.

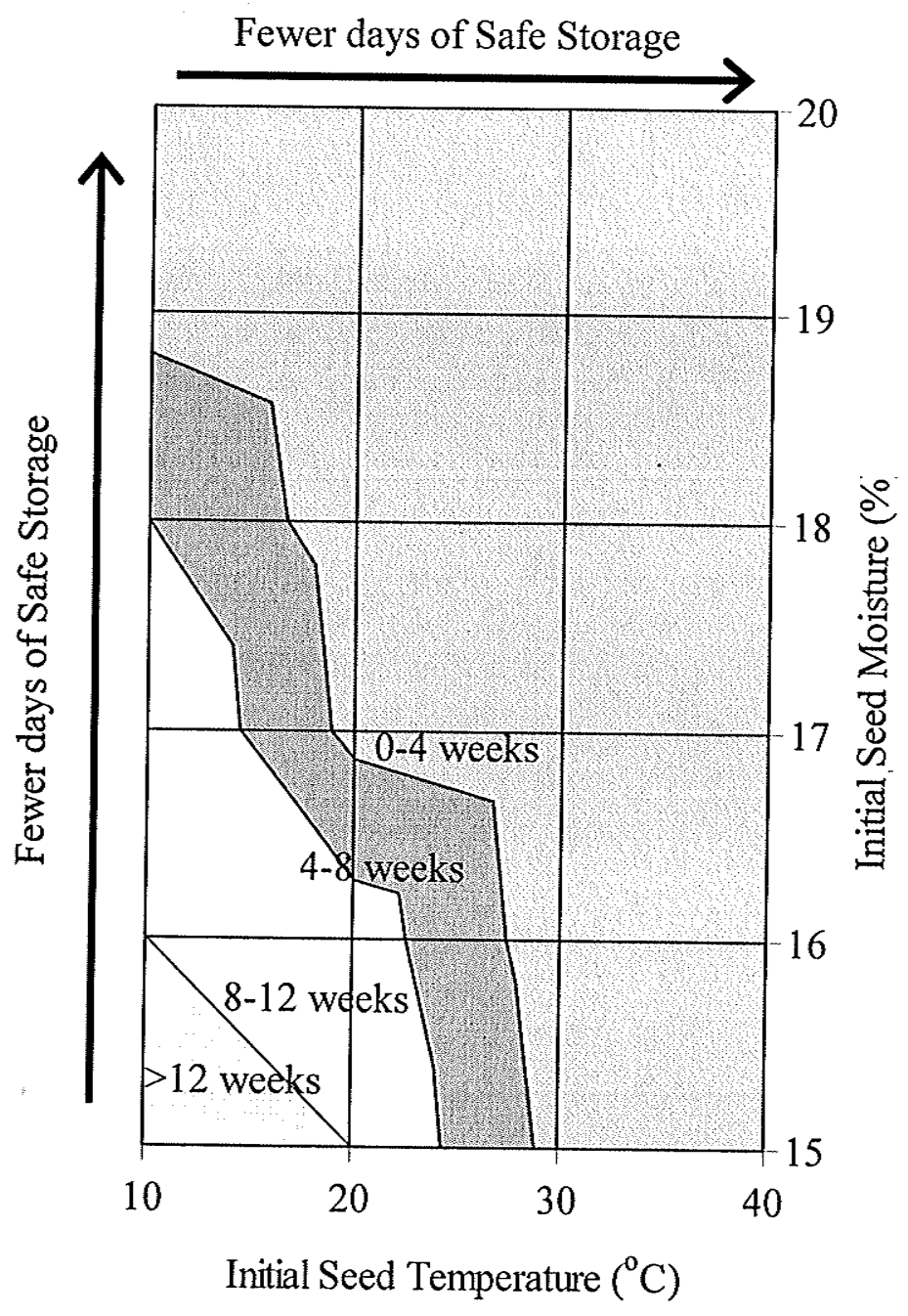

Fig. 6. Estimated safe storage life of durum wheat 
Fig. 7 gives the safe storage chart for wheat (hard red spring wheat). By comparing the safe storage chart for wheat and the safe storage chart for durum wheat (Fig. 6), it can be concluded that durum wheat deteriorates faster than hard red spring wheat. The comparison can only be made for grain stored at low moistures as there is no guideline for moisture greater than $18 \%$ for wheat. For instance, at $10^{\circ} \mathrm{C}$ durum wheat samples of 15 and $16 \%$ m.c. are safe for 12 weeks. From the safe storage life of wheat, samples at the same condition are safe for 6 months. So it can be concluded that durum wheat with 15 and $16 \%$ m.c. will also remain safe for 6 months when stored at $10^{\circ} \mathrm{C}$.

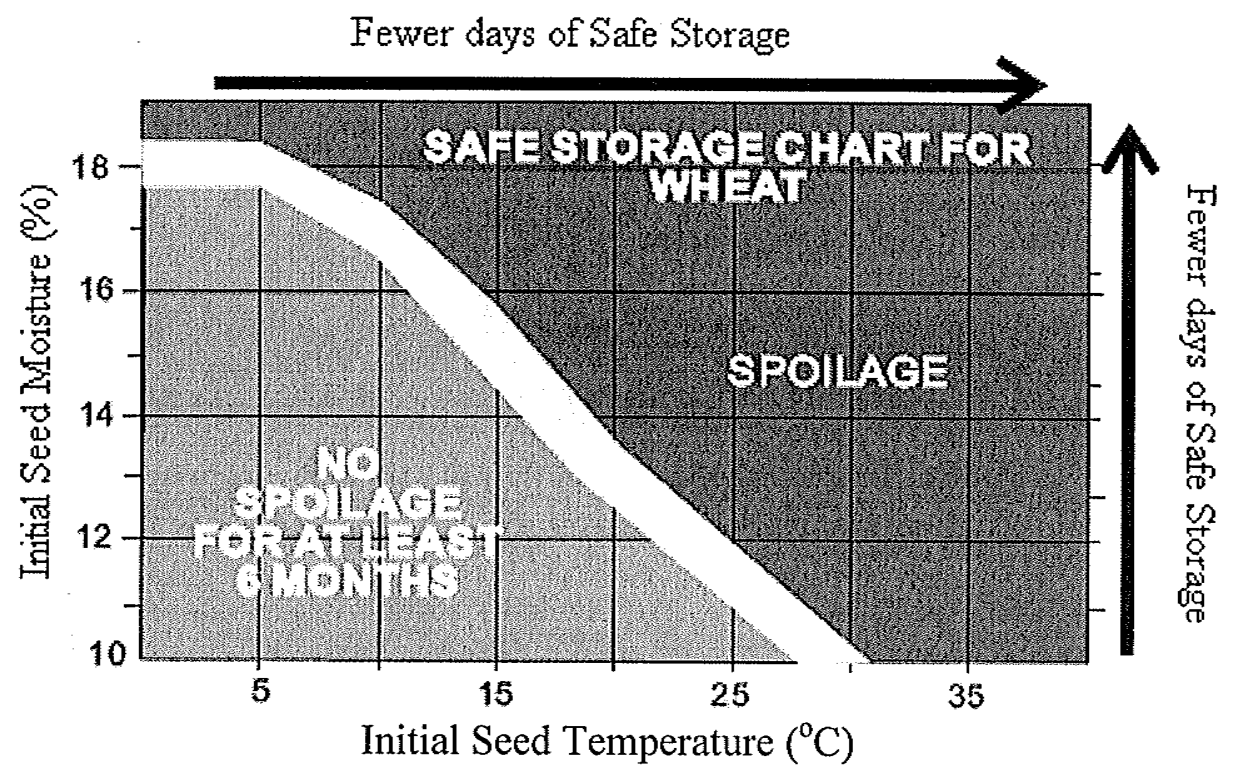

Fig.7. Safe storage life of wheat

Contrastingly for $15^{\circ} \mathrm{C}$, wheat with $15 \%$ m.c. was found to deteriorate only after 6 months and at the same conditions, durum wheat spoiled in 8-12 weeks. Fewer days of safe storage was observed during storage at high temperatures and moisture contents for both the cases. 


\section{CONCLUSIONS}

Moisture content, temperature and the length of storage significantly $(\alpha=0.05)$ affected the germination of durum wheat. Durum wheat with 15 and $16 \%$ m.c. can be stored for 12 weeks without any deterioration at 10 and $20^{\circ} \mathrm{C}$. However, if stored at $30^{\circ} \mathrm{C}$, the germination was affected in 4 weeks, and at $40^{\circ} \mathrm{C}$, the germination decreased to zero in the first week of storage. Thus even low moisture grain, if stored at high temperatures should be dried and cooled before 2 weeks of storage. If the grain is to be stored at 10 and $20^{\circ} \mathrm{C}$, with a moisture content of 17 and $18 \%$, it can have 7 weeks to be treated to prevent deterioration.

The samples with high moisture content were the first to show appearance of visible mould at all temperatures. The low moisture samples (15 and 16\% m.c.) stored at cooler temperatures $\left(10\right.$ and $\left.20^{\circ} \mathrm{C}\right)$ were devoid of any visible mould throughout the 12 wk of storage. Samples with high moisture stored at high temperatures showed visible mould from the start of the study. The predominant microfloral species (\% of seeds infected) found were Aspergillus and Penicillium; with A. glaucus group increasing with storage time. The changes in fat acidity value (FAV) were significantly affected by increase in temperature, moisture content and storage time. However at $40^{\circ} \mathrm{C}$, the FAV of high moisture samples were lower compared to the samples stored at $30^{\circ} \mathrm{C}$.

The samples with 15 and $16 \%$ m.c. can be safely stored without any quality loss for 12 weeks, if stored at 10 and $20^{\circ} \mathrm{C}$. The same moisture samples if stored at $30^{\circ} \mathrm{C}$ would have 4 weeks of time; and all other moisture samples $\left(17,18,19\right.$ and $\left.20^{\circ} \mathrm{C}\right)$ would only have 2 
weeks to conduct the post harvest treatments. The samples stored at $40^{\circ} \mathrm{C}$, irrespective of the moisture content, should be dried immediately (within one week) to prevent the quality deterioration of the grain. 


\section{RECOMMENDATIONS FOR FUTURE RESEARCH}

This work can be extended for other possible temperatures that will occur in Canada and for longer storage periods. Many other quality assessment factors such as nutritional changes, and milling and pasta making characteristics can be determined to find the effect of storage conditions on the quality of grain, and for further processing. 


\section{REFERENCES}

AACC. 1962. Fat acidity-general method. Method 02-01A (approved April 1961). In: Cereal laboratory methods, 7th ed. American Association of Cereal Chemists, St. Paul, MN.

Abramson D, R. Hulasare, N.D.G. White, D.S. Jayas and R.R. Marquardt. 1999. Mycotoxin formation in hullness barley during granary storage at 15\% and 19\% moisture content. Journal of Stored Products Research 35:297-305.

Adebajo, L.O, O.A. Bamgbelu and R.A. Olowu. 1994. Mould contamination and the influence of water activity and temperature on mycotoxin production by two Aspergilli in melon seed. Nahrung 38: 209-127.

Anonymous. 1997. Harvest yield high quality. In Grain Matters 1-2. Winnipeg, MB: Canadian Wheat Board.

ASAE. 2003. Moisture measurement - Unground Grain and Seeds. ASAE S352.2. In ASAE standards 2003, 555. St. Joseph, MI: ASAE.

Bala, B.K. 1997. Drying and Storage of Cereal Grains. Enfield, NH: Science Publishers Inc.

CAST. 2003. Mycotoxins: Risk in plant, animal and human systems. Report 139. Ames, Iowa: Council for Agricultural Science and Technology Task Force.

Christensen, C.M. and H.H. Kaufmann. 1969. Grain storage: the role of fungi in quality loss. Minneapolis, MN: University of Minnesota Press.

CWB. 2005. Statistical Tables. Winnipeg, MB: Canadian Wheat Board.

CWB. 2007. In a nutshell: A crop year-end review. Winnipeg, MB: Canadian Wheat Board.

FAO. 1990. Food and Agriculture Organization training in mycotoxins analysis. Food Nutrition Paper 14/10. Rome, Italy: FAO.

Hesseltine, C.W. 1976. Conditions leading to mycotoxin production of foods and feeds. In Mycotoxins and Other Fungal Related Food Problems, ed. J.V. Rodericks, 122. Washington, DC: American Chemical Society.

Jayas, D.S. 1995. Mathematical modeling of heat, moisture, and gas transfer in storedgrain ecosystems. In Stored-Grain Ecosystems, ed. D.S. Jayas, N.D.G. White and W.E. Muir, 123-167. New York, NY: Marcel Decker Inc. 
Jayas, D.S. and N.D.G. White. 2003. Storage and drying of grain in Canada: low cost approaches. Food Control 14:255-261.

JECFA. 1999. Position paper on ochratoxin. Programme 31. Rome, Italy: Joint FAO/WHO Food Standards.

Karunakaran, C. 1999. Modeling safe storage time of high (17 and 19\%) moisture content wheat. Unpublished M.Sc. thesis. Department of Biosystems Engineering, University of Manitoba, Winnipeg, MB. 65 p.

Kawamoto, H., R.N. Sinha and W.E. Muir. 1991. Regression models for estimation of temperature and moisture content of freshly harvested wheat and barley. Canadian Agricultural Engineering 33(2): 321-328.

Lennox, G. 2005. Durum wheat: 2005-2006 situation and outlook. Volume 18 (20). Ottawa, ON: Agriculture and Agri - Food Canada.

Lillehoj, E.B., D.I. Fennell and C.W. Hesseltine. 1975. Aspergillus flavus infection and aflatoxin production in mixtures of high-moisture and dry maize. Journal of Stored Products Research 11(1): 47-51.

Lombaert, G.A. 2003. Mycotoxins in infant cereal foods from Canadian retail market. Food Additives and Contaminants 20: 494-504.

Mills, J.T. 1996. Quality of stored cereals. In Cereal Grain Quality, ed. R.J. Hendry and P.S. Kettlewell, 441-478. London, UK: Chapman \& Hall.

Mills, J.T., R.N. Sinha and H.A.H. Wallace. 1978. Multivariate evaluation and isolation techniques for fungi associated with stored rapeseed. Phytopathology 68:15201525.

Muir, W.E. and D.S. Jayas. 1997. Temperature of stored grains and oilseeds. In Grain Preservation Biosystems, ed. W.E. Muir, 8-1 to 8-4. Winnipeg, MB, Department of Biosystems Engineering, University of Manitoba.

Pettit, R.E., R.A. Taber, H.W. Schroeder, and A.L. Harrison. 1971. Influence of fungicides and irrigation practice on aflatoxin in peanuts before digging. Applied Microbiology 22(4): 629-634

Pitt, J.I. and A.D. Hocking. 1985. Fungi and Food Spoilage. Sydney, AU: Sydney Academic Press.

Pitt, J.I. and A.D. Hocking. 1996. Significance of fungi in stored products. In Mycotoxin Contamination in Grains, ed. E. Highley and G.I. Johnson, 16-21. Canberra, AU: Australian Centre for International Agricultural Research. 
Pixton, S.W., S.Warburton and S.T. Hill. 1975. Long-term storage of wheat-III: Some changes in the quality of wheat observed during 16 years of storage. Journal of Stored Products Research 11(3-4):177-185.

Pomeranz, Y. 1992. Biochemical, functional and nutritive changes during storage. In Storage of Cereal Grains and Their Products, ed. J.A. Anderson and A.W. Alcock, 55-141. St. Paul, MN: American Association of Cereal Chemists.

Prasad, D.C., W.E. Muir and H.A.H. Wallace. 1978. Characteristics of freshly harvested wheat and rapeseed. Transactions of the ASAE 21(4):782-784.

Revankar, S.G. 2003. Clinical implications of mycotoxins and stachybotrys. American Journal of the Medical Sciences 325: 262-274.

Rudd, J.C., R.D. Horsley, A. L. McKendry and E.M. Elias. 2001. Host plant resistance genes for Fusarium head blight: sources, mechanisms, and utility in conventional breeding systems. Crop Science 41: 620-627.

Santin, E. 2005. Mould growth and mycotoxin production. In The Mycotoxin Blue Book, ed. D. Diaz, 225-234. Nottingham, UK: Nottingham University Press.

Sathya, G. 2006. Safe storage guidelines for canola and rye. Unpublished M.Sc. thesis. Winnipeg, MB: Department of Biosystems Engineering, University of Manitoba.

Schroeder, H.W. 1969. Factors influencing the development of aflatoxins in some field crops. Journal of Stored Products Research 5: 187-192.

Schroth, E., W.E. Muir, D.S. Jayas, N.D.G. White and D. Abramson. 1998. Storage limit of wheat at 17\% moisture content. Canadian Agricultural Engineering 40(3):201205.

Scott, W.J. 1957. Water relations of food spoilage micro-organisms. Advances in Food Research 7: 83-127.

Scudamore, K. A. and P. S. Breeze. 1999. Surveillance of stored grain from the 1997 United Kingdom harvest for ochratoxin A. Food Additives and Contaminants 16: 281-290.

Semeniuk, G. 1954. storage of cereal grains and their products. American Association of Cereal Chemists Monograph series II: 77-151.

Sinha, R.N. 1983. Effects of stored-product beetle infestation on fat acidity, seed germination, and microflora of wheat. Journal of Economic Entomology 76(4):813-817. 
Smith, J.E. and Henderson, R.S. 1991. Mycotoxins and Animal Foods. Boca Raton, FL: CRC Press.

Solomon, M.E. 1951. Control of humidity with potassium hydroxide, sulphuric acid, or other solutions. Bulletin of Entomological Research 42:543-554.

Sweeney, M.J. and A.D.W. Dobson.1998. Mycotoxin production by Aspergillus, Fusarium and Penicillium species. International Journal of Food Microbiology 43: 141-158.

Tipples, K.H. 1995. Quality and nutritional changes in stored grain. In Stored-Grain Ecosystems, ed. D.S. Jayas, N.D.G. White and W.E. Muir, 325-251. New York, NY: Marcel Decker Inc.

Tuite, J. 1994. Moulds, Mycotoxins and Food Preservatives in the Food Industry. Parsippany, NJ: BASF Corporation.

Twiddy, D.R. 1994. Volatiles as indicators of fungal growth on cereal grains. Tropical Science 34: 416-428.

Wallace, H.A.H. and R.N. Sinha. 1962. Fungi associated with hot spots in farm stored grain. Canadian Journal of Plant Science 42:130-141.

Wallace, H.A.H., P.L. Sholberg, R.N. Sinha and W.E. Muir. 1983. Biological, physical and chemical changes in stored wheat. Mycopathologia 82:65-72.

Wheler, K.A., B.F. Hurdman and J.I. Pitt. 1991. Influence of $\mathrm{pH}$ on the growth of some toxigenic species of Aspergillus, Penicillium and Fusarium. International Journal of Food Microbiology 55: 86-90.

White, N.D.G. 1995. Insects, mites, and insecticides in stored-grain ecosytems. In StoredGrain Ecosystems, ed. D.S. Jayas, N.D.G.White and W.E. Muir, 123-167. New York, NY: Marcel Decker Inc.

White, N.D.G. and R.N. Sinha. 1980. Changes in stored-wheat ecosystems infested with two combinations of insect species. Canadian Journal of Zoology 58:1524-1534.

White, N.D.G., R.B. Hulasare and D.S. Jayas. 1999. Effects of storage conditions on quality loss of hull-less and hulled oats and barely. Canadian Journal of Plant Science 79: 475-482.

Wyllie, T.D. and L.G. Morehouse. 1978. Mycotoxicoses of Man and Plants: Mycotoxin Control and Regulatory Practices. New York, NY: Marcel Dekker Inc. 
APPENDIX A: Germination data 
Table A1. Germination (\%) of durum wheat stored at $10^{\circ} \mathrm{C}$

\begin{tabular}{|c|c|c|c|c|c|c|c|}
\hline \multicolumn{8}{|c|}{ Moisture content $(\% \mathrm{wb})$} \\
\hline $\begin{array}{l}\text { Storage Period } \\
\text { (week) }\end{array}$ & Replicate & 15.0 & 16.0 & 17.0 & 18.0 & 19.0 & 20.0 \\
\hline \multirow{5}{*}{1} & a & 96 & 88 & 76 & 72 & 56 & 100 \\
\hline & $\mathrm{b}$ & 88 & 92 & 92 & 80 & 64 & 84 \\
\hline & $\mathrm{c}$ & 76 & 88 & 68 & 72 & 96 & 96 \\
\hline & mean & 86.67 & 89.33 & 78.67 & 74.66 & 72 & 93.33 \\
\hline & s.d.* & 10.06 & 2.31 & 12.22 & 4.61 & 21.17 & 8.33 \\
\hline \multirow{5}{*}{2} & a & 68 & 60 & 80 & 60 & 52 & 52 \\
\hline & $\mathrm{b}$ & 96 & 92 & 48 & 68 & 52 & 84 \\
\hline & $\mathrm{c}$ & 84 & 80 & 72 & 68 & 56 & 84 \\
\hline & mean & 82.67 & 77.33 & 66.67 & 65.33 & 53.33 & 73.33 \\
\hline & s.d. & 14.05 & 16.17 & 16.65 & 4.62 & 2.31 & 18.48 \\
\hline \multirow{5}{*}{3} & a & 80 & 88 & 60 & 96 & 92 & 80 \\
\hline & b & 76 & 76 & 76 & 92 & 64 & 64 \\
\hline & c & 72 & 80 & 84 & 92 & 72 & 80 \\
\hline & mean & 76.00 & 81.33 & 73.33 & 93.33 & 76.00 & 74.67 \\
\hline & s.d. & 1.00 & 1.53 & 3.06 & 0.58 & 3.61 & 2.31 \\
\hline \multirow{5}{*}{4} & $\mathrm{a}$ & 72 & 76 & 76 & 76 & 64 & 60 \\
\hline & b & 80 & 56 & 48 & 76 & 48 & 48 \\
\hline & $\mathrm{c}$ & 76 & 88 & 60 & 72 & 68 & 56 \\
\hline & mean & 76.00 & 73.33 & 61.33 & 74.67 & 60 & 54.67 \\
\hline & s.d. & 4.00 & 16.17 & 14.05 & 2.31 & 10.58 & 6.11 \\
\hline \multirow{5}{*}{5} & a & 88 & 80 & 68 & 84 & 52 & 40 \\
\hline & b & 84 & 72 & 60 & 76 & 68 & 32 \\
\hline & $\mathrm{c}$ & 76 & 76 & 80 & 92 & 52 & 48 \\
\hline & mean & 82.67 & 76.00 & 69.33 & 84.00 & 57.33 & 40.00 \\
\hline & s.d. & 6.11 & 4.00 & 10.07 & 8.00 & 9.23 & 8.00 \\
\hline \multirow{5}{*}{6} & a & 92 & 76 & 84 & 64 & 68 & 48 \\
\hline & b & 88 & 76 & 72 & 84 & 56 & 32 \\
\hline & c & 76 & 84 & 84 & 80 & 84 & 32 \\
\hline & mean & 85.33 & 78.67 & 80.00 & 76.00 & 69.33 & 37.33 \\
\hline & s.d. & 8.33 & 4.62 & 6.93 & 10.58 & 14.05 & 9.24 \\
\hline
\end{tabular}




\begin{tabular}{|c|c|c|c|c|c|c|c|}
\hline \multicolumn{8}{|c|}{ Moisture content $(\% \mathrm{wb})$} \\
\hline $\begin{array}{l}\text { Storage Period } \\
\text { (week) }\end{array}$ & Replicate & 15.0 & 16.0 & 17.0 & 18.0 & 19.0 & 20.0 \\
\hline \multirow{5}{*}{7} & a & 80 & 72 & 68 & 80 & 36 & 44 \\
\hline & b & 76 & 56 & 64 & 88 & 44 & 28 \\
\hline & $\mathrm{c}$ & 72 & 76 & 76 & 80 & 16 & 48 \\
\hline & mean & 76.00 & 68.00 & 69.33 & 82.67 & 32.00 & 40.00 \\
\hline & s.d. & 4.00 & 10.58 & 6.11 & 4.62 & 14.42 & 10.58 \\
\hline \multirow{5}{*}{8} & a & 68 & 72 & 64 & 88 & 32 & 28 \\
\hline & $\mathrm{b}$ & 80 & 68 & 52 & 88 & 24 & 28 \\
\hline & $\mathrm{c}$ & 80 & 64 & 76 & 72 & 28 & 36 \\
\hline & mean & 77.33 & 68.00 & 64.00 & 82.67 & 28.00 & 30.67 \\
\hline & s.d. & 8.33 & 4.00 & 12.00 & $9: 24$ & 4.00 & 4.62 \\
\hline \multirow{5}{*}{9} & a & 96 & 80 & 76 & 72 & 24 & 24 \\
\hline & b & 64 & 68 & 64 & 60 & 32 & 32 \\
\hline & $\mathrm{c}$ & 88 & 44 & 72 & 76 & 12 & 36 \\
\hline & mean & 82.67 & 64.00 & 70.67 & 69.33 & 22.67 & 30.67 \\
\hline & s.d. & 16.65 & 18.33 & 6.11 & 8.33 & 10.07 & 6.11 \\
\hline \multirow{5}{*}{10} & $\mathrm{a}$ & 60 & 88 & 56 & 52 & 12 & 28 \\
\hline & b & 88 & 88 & 88 & 68 & 28 & 20 \\
\hline & $\mathrm{c}$ & 72 & 68 & 72 & 60 & 12 & 28 \\
\hline & mean & 73.33 & 81.33 & 72.00 & 60.00 & 17.33 & 25.33 \\
\hline & s.d. & 14.05 & 11.55 & 16.00 & 8.00 & 9.24 & 4.62 \\
\hline \multirow{5}{*}{11} & $\mathrm{a}$ & 92 & 84 & 92 & 84 & 16 & 20 \\
\hline & b & 100 & 96 & 60 & 72 & 28 & 28 \\
\hline & c & 92 & 76 & 76 & 72 & 36 & 40 \\
\hline & mean & 94.67 & 85.33 & 76.00 & 76.00 & 26.67 & 29.33 \\
\hline & s.d. & 4.62 & 10.06 & 16.00 & 6.93 & 10.06 & 10.06 \\
\hline \multirow{5}{*}{12} & $\mathrm{a}$ & 84 & 80 & 80 & 68 & 8 & 12 \\
\hline & $b$ & 92 & 96 & 68 & 64 & 20 & 8 \\
\hline & c & 92 & 92 & 76 & 68 & 20 & 16 \\
\hline & mean & 89.33 & 89.33 & 74.67 & 66.67 & 16.00 & 12.00 \\
\hline & s.d. & 4.62 & 8.33 & 6.11 & 2.31 & 6.93 & 4.00 \\
\hline
\end{tabular}

* Standard deviation of the replicates from the mean 
Table A2. Germination (\%) of durum wheat stored at $20^{\circ} \mathrm{C}$

\begin{tabular}{|c|c|c|c|c|c|c|c|}
\hline \multicolumn{8}{|c|}{ Moisture content $(\% \mathrm{wb})$} \\
\hline $\begin{array}{l}\text { Storage Period } \\
\text { (week) }\end{array}$ & Replicate & 15.0 & 16.0 & 17.0 & 18.0 & 19.0 & 20.0 \\
\hline \multirow{5}{*}{1} & a & 92 & 96 & 88 & 80 & 72 & 88 \\
\hline & $\mathrm{b}$ & 84 & 80 & 80 & 84 & 92 & 84 \\
\hline & $\mathrm{c}$ & 92 & 84 & 76 & 76 & 92 & 88 \\
\hline & mean & 89.33 & 86.67 & 81.33 & 80.00 & 85.33 & 86.67 \\
\hline & s.d. & 4.62 & 8.33 & 6.11 & 4.00 & 11.55 & 2.31 \\
\hline \multirow{5}{*}{2} & a & 92 & 92 & 76 & 88 & 64 & 52 \\
\hline & $\mathrm{b}$ & 84 & 88 & 84 & 96 & 60 & 48 \\
\hline & c & 84 & 96 & 80 & 84 & 72 & 60 \\
\hline & mean & 86.67 & 92.00 & 82.00 & 89.33 & 65.33 & 53.33 \\
\hline & s.d. & 4.62 & 4.00 & 4.00 & 6.11 & 6.11 & 6.11 \\
\hline \multirow{5}{*}{3} & a & 86 & 78 & 78 & 62 & 42 & 38 \\
\hline & b & 88 & 80 & 74 & 70 & 44 & 30 \\
\hline & $\mathrm{c}$ & 82 & 80 & 60 & 60 & 42 & 32 \\
\hline & mean & 85.33 & 79.33 & 70.67 & 64.00 & 42.67 & 33.33 \\
\hline & s.d. & 3.06 & 1.15 & 9.45 & 5.29 & 1.15 & 4.16 \\
\hline \multirow{5}{*}{4} & a & 76 & 80 & 60 & 32 & 24 & 28 \\
\hline & $\mathrm{b}$ & 76 & 64 & 72 & 36 & 32 & 32 \\
\hline & $c$ & 76 & 80 & 72 & 48 & 28 & 32 \\
\hline & mean & 76.00 & 74.67 & 68.00 & 38.67 & 28.00 & 30.67 \\
\hline & s.d. & 0.00 & 9.24 & 6.93 & 8.33 & 4.00 & 2.31 \\
\hline \multirow{5}{*}{5} & a & 84 & 64 & 68 & 32 & 40 & 28 \\
\hline & b & 84 & 76 & 60 & 32 & 28 & 12 \\
\hline & $\mathrm{c}$ & 80 & 68 & 48 & 32 & 24 & 24 \\
\hline & mean & 82.67 & 69.33 & 58.67 & 32.00 & 30.67 & 21.33 \\
\hline & s.d. & 2.31 & 6.11 & 10.07 & 0.00 & 8.33 & 8.33 \\
\hline \multirow{5}{*}{6} & $\mathrm{a}$ & 88 & 68 & 48 & 12 & 20 & 20 \\
\hline & b & 80 & 88 & 44 & 12 & 24 & 8 \\
\hline & $\mathrm{c}$ & 84 & 80 & 36 & 20 & 16 & 20 \\
\hline & mean & 84.00 & 78.67 & 42.67 & 14.67 & 20.00 & 16.00 \\
\hline & s.d. & 4.00 & 10.07 & 6.11 & 4.62 & 4.00 & 6.93 \\
\hline
\end{tabular}




\begin{tabular}{|c|c|c|c|c|c|c|c|}
\hline \multicolumn{8}{|c|}{ Moisture content $(\% \mathrm{wb})$} \\
\hline $\begin{array}{l}\text { Storage Period } \\
\text { (week) }\end{array}$ & Replicate & 15.0 & 16.0 & 17.0 & 18.0 & 19.0 & 20.0 \\
\hline \multirow{5}{*}{7} & a & 76 & 64 & 48 & 20 & 32 & 12 \\
\hline & $\mathrm{b}$ & 80 & 76 & 44 & 12 & 8 & 40 \\
\hline & $\mathrm{c}$ & 64 & 72 & 40 & 32 & 48 & 4 \\
\hline & mean & 73.33 & 70.67 & 44.00 & 21.33 & 29.33 & 18.67 \\
\hline & s.d. & 8.33 & 6.11 & 4.00 & 10.07 & 20.13 & 18.90 \\
\hline \multirow{5}{*}{8} & a & 84 & 68 & 56 & 32 & 28 & 32 \\
\hline & $\mathrm{b}$ & 80 & 68 & 40 & 36 & 16 & 24 \\
\hline & $\mathrm{c}$ & 76 & 76 & 48 & 28 & 20 & 20 \\
\hline & mean & 80.00 & 70.67 & 48.00 & 32.00 & 21.33 & 25.33 \\
\hline & s.d. & 4.00 & 4.62 & 8.00 & 4.00 & 6.11 & 6.11 \\
\hline \multirow{5}{*}{9} & $\mathrm{a}$ & 80 & 68 & 36 & 4 & 24 & 12 \\
\hline & b & 68 & 76 & 52 & 16 & 16 & 16 \\
\hline & $\mathrm{c}$ & 84 & 72 & 48 & 8 & 24 & 24 \\
\hline & mean & 77.33 & 72.00 & 45.33 & 9.33 & 21.33 & 17.33 \\
\hline & s.d. & 8.33 & 4.00 & 8.33 & 6.11 & 4.62 & 6.11 \\
\hline \multirow{5}{*}{10} & $\mathrm{a}$ & 80 & 80 & 28 & 12 & 12 & 20 \\
\hline & b & 80 & 72 & 28 & 12 & 24 & 20 \\
\hline & $\mathrm{c}$ & 76 & 68 & 52 & 12 & 20 & 12 \\
\hline & mean & 78.67 & 73.33 & 36.00 & 12.00 & 18.67 & 17.33 \\
\hline & s.d. & 2.31 & 6.11 & 13.86 & 0.00 & 6.11 & 4.62 \\
\hline \multirow{5}{*}{11} & a & 52 & 76 & 40 & 12 & 12 & 16 \\
\hline & b & 72 & 56 & 52 & 16 & 12 & 4 \\
\hline & c & 88 & 68 & 28 & 20 & 16 & 8 \\
\hline & mean & 70.67 & 66.67 & 40.00 & 16.00 & 13.33 & 9.33 \\
\hline & s.d. & 18.04 & 10.07 & 12.00 & 4.00 & 2.31 & 6.11 \\
\hline \multirow{5}{*}{12} & a & 80 & 64 & 36 & 40 & 28 & 8 \\
\hline & b & 68 & 72 & 20 & 32 & 16 & 8 \\
\hline & $c$ & 84 & 56 & 32 & 20 & 28 & 0 \\
\hline & mean & 77.33 & 64.00 & 29.33 & 30.67 & 24.00 & 5.33 \\
\hline & s.d. & 8.33 & 8.00 & 8.33 & 10.07 & 6.93 & 4.62 \\
\hline
\end{tabular}


Table A3. Germination (\%) of durum wheat stored at $30^{\circ} \mathrm{C}$

\begin{tabular}{|c|c|c|c|c|c|c|c|}
\hline \multicolumn{8}{|c|}{ Moisture content $(\% \mathrm{wb})$} \\
\hline $\begin{array}{l}\text { Storage Period } \\
\text { (week) }\end{array}$ & Replicate & 15.0 & 16.0 & 17.0 & 18.0 & 19.0 & 20.0 \\
\hline \multirow{5}{*}{1} & a & 88 & 92 & 84 & 92 & 72 & 80 \\
\hline & $\mathrm{b}$ & 92 & 84 & 84 & 80 & 68 & 72 \\
\hline & $\mathrm{c}$ & 92 & 80 & 76 & 80 & 72 & 64 \\
\hline & mean & 90.67 & 85.33 & 81.33 & 84.00 & 70.67 & 72.00 \\
\hline & s.d. & 2.31 & 6.11 & 4.62 & 6.93 & 2.31 & 8.00 \\
\hline \multirow{5}{*}{2} & a & 84 & 80 & 56 & 36 & 20 & 12 \\
\hline & b & 80 & 88 & 44 & 44 & 20 & 16 \\
\hline & $\mathrm{c}$ & 84 & 88 & 56 & 28 & 24 & 24 \\
\hline & mean & 82.67 & 85.33 & 52.00 & 36.00 & 21.33 & 17.33 \\
\hline & s.d. & 2.31 & 4.62 & 6.93 & 8.00 & 2.31 & 6.11 \\
\hline \multirow{5}{*}{3} & $\mathrm{a}$ & 76 & 64 & 48 & 32 & 14 & 12 \\
\hline & b & 70 & 60 & 46 & 26 & 18 & 8 \\
\hline & $\mathrm{c}$ & 70 & 64 & 40 & 30 & 14 & 4 \\
\hline & mean & 72.00 & 62.67 & 44.67 & 29.33 & 15.33 & 8.67 \\
\hline & s.d. & 3.46 & 2.31 & 4.16 & 3.06 & 2.31 & 3.06 \\
\hline \multirow{5}{*}{4} & a & 56 & 40 & 24 & 4 & 8 & 8 \\
\hline & b & 48 & 36 & 20 & 8 & 12 & 4 \\
\hline & c & 76 & 36 & 16 & 16 & 8 & 8 \\
\hline & mean & 16.00 & 37.33 & 20.00 & 9.33 & 9.33 & 6.67 \\
\hline & s.d. & 14.42 & 2.31 & 4.00 & 6.11 & 2.31 & 2.31 \\
\hline \multirow{5}{*}{5} & a & 16 & 36 & 12 & 0 & 0 & 0 \\
\hline & b & 52 & 16 & 16 & 8 & 4 & 0 \\
\hline & $\mathrm{c}$ & 32 & 20 & 8 & 0 & 12 & 0 \\
\hline & mean & 33.33 & 24.00 & 12.00 & 2.67 & 5.33 & 0.00 \\
\hline & s.d. & 18.04 & 10.58 & 4.00 & 4.61 & 6.11 & 0.00 \\
\hline \multirow{5}{*}{6} & a & 24 & 20 & 4 & 0 & 0 & 0 \\
\hline & $b$ & 28 & 8 & 0 & 0 & 0 & 0 \\
\hline & $\mathrm{c}$ & 24 & 20 & 12 & 0 & 0 & 0 \\
\hline & mean & 25.33 & 16.00 & 5.33 & 0.00 & 0.00 & 0.00 \\
\hline & s.d. & 2.31 & 6.93 & 6.11 & 0.00 & 0.00 & 0.00 \\
\hline
\end{tabular}




\begin{tabular}{|c|c|c|c|c|c|c|c|}
\hline \multicolumn{8}{|c|}{ Moisture content (\% wb) } \\
\hline $\begin{array}{c}\text { Storage Period } \\
\text { (week) }\end{array}$ & Replicate & 15.0 & 16.0 & 17.0 & 18.0 & 19.0 & 20.0 \\
\hline \multirow{5}{*}{7} & a & 8 & 12 & 24 & 0 & 0 & 0 \\
\hline & $b$ & 32 & 8 & 20 & 0 & 0 & 0 \\
\hline & $\mathrm{c}$ & 28 & 20 & 16 & 0 & 0 & 0 \\
\hline & mean & 22.67 & 13.33 & 20.00 & 0.00 & 0.00 & 0.00 \\
\hline & s.d. & 12.86 & 6.11 & 4.00 & 0.00 & 0.00 & 0.00 \\
\hline \multirow{5}{*}{8} & a & 8 & 16 & 12 & 0 & 0 & 0 \\
\hline & $b$ & 8 & 16 & 4 & 0 & 0 . & 0 \\
\hline & $\mathrm{c}$ & 16 & 32 & 0 & 0 & 0 & 0 \\
\hline & mean & 10.67 & 21.33 & 5.33 & 0.00 & 0.00 & 0.00 \\
\hline & s.d. & 4.61 & 9.24 & 6.11 & 0.00 & 0.00 & 0.00 \\
\hline \multirow{5}{*}{9} & a & 16 & 4 & 0 & 0 & 0 & 0 \\
\hline & b & 8 & 0 & 0 & 0 & 0 & 0 \\
\hline & $\mathrm{c}$ & 20 & 8 & 0 & 0 & 0 & 0 \\
\hline & mean & 14.67 & 4.00 & 0.00 & 0.00 & 0.00 & 0.00 \\
\hline & s.d. & 6.11 & 4.00 & 0.00 & 0.00 & 0.00 & 0.00 \\
\hline \multirow{5}{*}{10} & a & 0 & 16 & 0 & 0 & 0 & 0 \\
\hline & b & 12 & 4 & 0 & 0 & 0 & 0 \\
\hline & $\mathrm{c}$ & 4 & 4 & 0 & 0 & 0 & 0 \\
\hline & mean & 5.33 & 8.00 & 0.00 & 0.00 & 0.00 & 0.00 \\
\hline & s.d. & 6.11 & 6.93 & 0.00 & 0.00 & 0.00 & 0.00 \\
\hline \multirow{5}{*}{11} & $\mathrm{a}$ & 12 & 0 & 0 & 0 & 0 & 0 \\
\hline & b & 4 & 0 & 0 & 0 & 0 & 0 \\
\hline & $\mathrm{c}$ & 12 & 0 & 0 & 0 & 0 & 0 \\
\hline & mean & 9.33 & 0.00 & 0.00 & 0.00 & 0.00 & 0.00 \\
\hline & s.d. & 4.62 & 0.00 & 0.00 & 0.00 & 0.00 & 0.00 \\
\hline \multirow{5}{*}{12} & a & 0 & 0 & 0 & 0 & 0 & 0 \\
\hline & b & 16 & 0 & 0 & 0 & 0 & 0 \\
\hline & $\mathrm{c}$ & 4 & 0 & 0 & 0 & 0 & 0 \\
\hline & mean & 6.67 & 0.00 & 0.00 & 0.00 & 0.00 & 0.00 \\
\hline & s.d. & 8.33 & 0.00 & 0.00 & 0.00 & 0.00 & 0.00 \\
\hline
\end{tabular}


Table A4. Germination (\%) of durum wheat stored at $40^{\circ} \mathrm{C}$

\begin{tabular}{|c|c|c|c|c|c|c|c|}
\hline \multicolumn{8}{|c|}{ Moisture content $(\% \mathrm{wb})$} \\
\hline $\begin{array}{l}\text { Storage Period } \\
\text { (week) }\end{array}$ & Replicate & 15.0 & 16.0 & 17.0 & 18.0 & 19.0 & 20.0 \\
\hline \multirow{5}{*}{1} & $\mathrm{a}$ & 60 & 44 & 32 & 20 & 4 & 12 \\
\hline & $\mathrm{b}$ & 64 & 48 & 20 & 28 & 12 & 8 \\
\hline & $\mathrm{c}$ & 48 & 56 & 16 & 24 & 8 & 8 \\
\hline & mean & 57.33 & 49.33 & 22.67 & 24.00 & 8.00 & 9.33 \\
\hline & s.d. & 8.33 & 6.11 & 8.33 & 4.00 & 4.00 & 2.31 \\
\hline \multirow{5}{*}{2} & a & 28 & 0 & 0 & 8 & 0 & 0 \\
\hline & $\mathrm{b}$ & 16 & 0 & 8 & 16 & 0 & 4 \\
\hline & $\mathrm{c}$ & 32 & 0 & 0 & 16 & 0 & 0 \\
\hline & mean & 26.67 & 0.00 & 2.67 & 13.33 & 0.00 & 1.33 \\
\hline & s.d. & 10.07 & 0.00 & 4.62 & 4.62 & 0.00 & 2.31 \\
\hline \multirow{5}{*}{3} & $\mathrm{a}$ & 8 & 0 & 0 & 0 & 0 & 0 \\
\hline & $\mathrm{b}$ & 12 & 0 & 0 & 0 & 0 & 0 \\
\hline & $\mathrm{c}$ & 4 & 0 & 0 & 0 & 0 & 0 \\
\hline & mean & 8.00 & 0.00 & 0.00 & 0.00 & 0.00 & 0.00 \\
\hline & s.d. & 4.00 & 0.00 & 0.00 & 0.00 & 0.00 & 0.00 \\
\hline \multirow{5}{*}{4} & a & 8 & 0 & 0 & 0 & 0 & 0 \\
\hline & $\mathrm{b}$ & 0 & 0 & 0 & 0 & 0 & 0 \\
\hline & $\mathrm{c}$ & 0 & 0 & 0 & 0 & 0 & 0 \\
\hline & mean & 2.67 & 0.00 & 0.00 & 0.00 & 0.00 & 0.00 \\
\hline & s.d. & 4.62 & 0.00 & 0.00 & 0.00 & 0.00 & 0.00 \\
\hline \multirow{5}{*}{5} & a & 0 & 0 & 0 & 0 & 0 & 0 \\
\hline & b & 0 & 0 & 0 & 0 & 0 & 0 \\
\hline & $\mathrm{c}$ & 0 & 0 & 0 & 0 & 0 & 0 \\
\hline & mean & 0.00 & 0.00 & 0.00 & 0.00 & 0.00 & 0.00 \\
\hline & s.d. & 0.00 & 0.00 & 0.00 & 0.00 & 0.00 & 0.00 \\
\hline \multirow{5}{*}{6} & $\mathrm{a}$ & 0 & 0 & 0 & 0 & 0 & 0 \\
\hline & b & 0 & 0 & 0 & 0 & 0 & 0 \\
\hline & $\mathrm{c}$ & 0 & 0 & 0 & 0 & 0 & 0 \\
\hline & mean & 0.00 & 0.00 & 0.00 & 0.00 & 0.00 & 0.00 \\
\hline & s.d. & 0.00 & 0.00 & 0.00 & 0.00 & 0.00 & 0.00 \\
\hline
\end{tabular}




\begin{tabular}{|c|c|c|c|c|c|c|c|}
\hline \multicolumn{8}{|c|}{ Moisture content (\% wb) } \\
\hline $\begin{array}{l}\text { Storage Period } \\
\text { (week) }\end{array}$ & Replicate & 15.0 & 16.0 & 17.0 & 18.0 & 19.0 & 20.0 \\
\hline \multirow{5}{*}{7} & a & 0 & 0 & 0 & 0 & 0 & 0 \\
\hline & $b$ & 0 & 0 & 0 & 0 & 0 & 0 \\
\hline & $\mathrm{c}$ & 0 & 0 & 0 & 0 & 0 & 0 \\
\hline & mean & 0.00 & 0.00 & 0.00 & 0.00 & 0.00 & 0.00 \\
\hline & s.d. & 0.00 & 0.00 & 0.00 & 0.00 & 0.00 & 0.00 \\
\hline \multirow{5}{*}{8} & a & 0 & 0 & 0 & 0 & 0 & 0 \\
\hline & $\mathrm{b}$ & 0 & 0 & 0 & 0 & 0 & 0 \\
\hline & $\mathrm{c}$ & 0 & 0 & 0 & 0 & 0 & 0 \\
\hline & mean & 0.00 & 0.00 & 0.00 & 0.00 & 0.00 & 0.00 \\
\hline & s.d. & 0.00 & 0.00 & 0.00 & 0.00 & 0.00 & 0.00 \\
\hline \multirow{5}{*}{9} & a & 0 & 0 & 0 & 0 & 0 & 0 \\
\hline & $b$ & 0 & 0 & 0 & 0 & 0 & 0 \\
\hline & $\mathrm{c}$ & 0 & 0 & 0 & 0 & 0 & 0 \\
\hline & mean & 0.00 & 0.00 & 0.00 & 0.00 & 0.00 & 0.00 \\
\hline & s.d. & 0.00 & 0.00 & 0.00 & 0.00 & 0.00 & 0.00 \\
\hline \multirow{5}{*}{10} & $\mathrm{a}$ & 0 & 0 & 0 & 0 & 0 & 0 \\
\hline & b & 0 & 0 & 0 & 0 & 0 & 0 \\
\hline & $\mathrm{c}$ & 0 & 0 & 0 & 0 & 0 & 0 \\
\hline & mean & 0.00 & 0.00 & 0.00 & 0.00 & 0.00 & 0.00 \\
\hline & s.d. & 0.00 & 0.00 & 0.00 & 0.00 & 0.00 & 0.00 \\
\hline \multirow{5}{*}{11} & $\mathrm{a}$ & 0 & 0 & 0 & 0 & 0 & 0 \\
\hline & b & 0 & 0 & 0 & 0 & 0 & 0 \\
\hline & $\mathrm{c}$ & 0 & 0 & 0 & 0 & 0 & 0 \\
\hline & mean & 0.00 & 0.00 & 0.00 & 0.00 & 0.00 & 0.00 \\
\hline & s.d. & 0.00 & 0.00 & 0.00 & 0.00 & 0.00 & 0.00 \\
\hline \multirow{5}{*}{12} & $\mathrm{a}$ & 0 & 0 & 0 & 0 & 0 & 0 \\
\hline & b & 0 & 0 & 0 & 0 & 0 & 0 \\
\hline & $\mathrm{c}$ & 0 & 0 & 0 & 0 & 0 & 0 \\
\hline & mean & 0.00 & 0.00 & 0.00 & 0.00 & 0.00 & 0.00 \\
\hline & s.d. & 0.00 & 0.00 & 0.00 & 0.00 & 0.00 & 0.00 \\
\hline
\end{tabular}


APPENDIX B: Moisture content data 
Table B1. Moisture content of durum wheat stored at $10^{\circ} \mathrm{C}$

\begin{tabular}{|c|c|c|c|c|c|c|c|}
\hline \multicolumn{8}{|c|}{ Initial moisture content $(\% \mathrm{wb})$} \\
\hline $\begin{array}{l}\text { Storage Period } \\
\text { (week) }\end{array}$ & Replicate & 15.0 & 16.0 & 17.0 & 18.0 & 19.0 & 20.0 \\
\hline \multirow{5}{*}{1} & a & 15.1 & 15.7 & 16.5 & 17.9 & 19.2 & 20.2 \\
\hline & $\mathrm{b}$ & 14.9 & 16.2 & 16.7 & 18.3 & 19.3 & 20.5 \\
\hline & $\mathrm{c}$ & 15.1 & 16.0 & 17.0 & 18.0 & 19.5 & 19.9 \\
\hline & mean & 15.10 & 16.03 & 16.78 & 18.12 & 19.38 & 20.23 \\
\hline & s.d. & 0.16 & 0.35 & 0.11 & 0.32 & 0.08 & 0.21 \\
\hline \multirow{5}{*}{2} & $\mathrm{a}$ & 15.0 & 15.7 & 16.7 & 17.9 & 19.3 & 20.6 \\
\hline & $\mathrm{b}$ & 14.8 & 15.9 & 16.6 & 18.1 & 19.1 & 21.0 \\
\hline & $\mathrm{c}$ & 14.8 & 15.9 & 16.6 & 18.0 & 19.3 & 19.7 \\
\hline & mean & 14.93 & 15.86 & 16.68 & 18.07 & 19.27 & 20.49 \\
\hline & s.d. & 0.16 & 0.14 & 0.04 & 0.08 & 0.15 & 0.67 \\
\hline \multirow{5}{*}{3} & a & 15.1 & 16.4 & 16.4 & 18.1 & 18.7 & 20.1 \\
\hline & b & 15.0 & 16.1 & 17.1 & 18.0 & 18.7 & 19.5 \\
\hline & $\mathrm{c}$ & 15.3 & 15.9 & 16.9 & 18.0 & 19.2 & 20.4 \\
\hline & mean & 15.17 & 16.20 & 16.84 & 18.10 & 18.94 & 20.04 \\
\hline & s.d. & 0.17 & 0.28 & 0.36 & 0.03 & 0.30 & 0.41 \\
\hline \multirow{5}{*}{4} & $\mathrm{a}$ & 15.1 & 14.8 & 15.9 & 18.3 & 18.8 & 19.4 \\
\hline & $\mathrm{b}$ & 15.0 & 14.6 & 16.4 & 18.3 & 19.0 & 20.1 \\
\hline & $\mathrm{c}$ & 15.1 & 14.4 & 15.6 & 17.9 & 18.9 & 19.6 \\
\hline & mean & 13.83 & 14.65 & 15.40 & 16.52 & 17.50 & 18.47 \\
\hline & s.d. & 0.47 & 0.22 & 0.20 & 0.10 & 0.28 & 0.58 \\
\hline \multirow{5}{*}{5} & $\mathrm{a}$ & 15.0 & 15.4 & 16.4 & 18.1 & 18.8 & 19.9 \\
\hline & b & 15.0 & 15.7 & 16.5 & 18.2 & 18.7 & 19.9 \\
\hline & $\mathrm{c}$ & 15.0 & 15.3 & 16.6 & 18.1 & 18.9 & 19.9 \\
\hline & mean & 15.00 & 15.47 & 16.50 & 18.13 & 18.80 & 19.90 \\
\hline & s.d. & 0.00 & 0.21 & 0.10 & 0.06 & 0.1 & 0.00 \\
\hline \multirow{5}{*}{6} & $\mathrm{a}$ & 15.2 & 16.2 & 16.2 & 18.0 & 19.3 & 20.5 \\
\hline & b & 15.5 & 16.3 & 17.2 & 18.7 & 18.9 & 19.7 \\
\hline & $\mathrm{c}$ & 14.7 & 15.6 & 16.2 & 17.6 & 18.6 & 19.6 \\
\hline & mean & 13.56 & 14.63 & 15.25 & 16.78 & 17.46 & 18.65 \\
\hline & s.d. & 0.14 & 0.12 & 0.11 & 0.27 & 0.38 & 0.12 \\
\hline
\end{tabular}




\begin{tabular}{|c|c|c|c|c|c|c|c|}
\hline \multicolumn{8}{|c|}{ Initial moisture content $(\% \mathrm{wb})$} \\
\hline $\begin{array}{c}\text { Storage Period } \\
\text { (week) }\end{array}$ & Replicate & 15.0 & 16.0 & 17.0 & 18.0 & 19.0 & 20.0 \\
\hline \multirow{5}{*}{7} & a & 14.9 & 16.2 & 17.0 & 18.2 & 19.2 & 20.0 \\
\hline & $\mathrm{b}$ & 15.2 & 16.1 & 16.8 & 18.2 & 19.4 & 20.3 \\
\hline & $\mathrm{c}$ & 15.4 & 16.4 & 16.9 & 17.9 & 19.1 & 20.0 \\
\hline & mean & 15.21 & 16.28 & 19.98 & 18.16 & 19.27 & 20.11 \\
\hline & s.d. & 0.22 & 0.14 & 0.09 & 0.19 & 0.13 & 0.17 \\
\hline \multirow{5}{*}{8} & a & 15.1 & 16.3 & 17.0 & 17.6 & 19.2 & 19.8 \\
\hline & $\mathrm{b}$ & 15.2 & 16.3 & 17.0 & 17.8 & 19.0 & 20.2 \\
\hline & $\mathrm{c}$ & 15.2 & 16.3 & 17.3 & 17.9 & 19.1 & 21.1 \\
\hline & mean & 15.21 & 16.30 & 17.14 & 17.82 & 19.13 & 20.07 \\
\hline & s.d. & 0.05 & 0.00 & 0.01 & 0.20 & 0.12 & 0.24 \\
\hline \multirow{5}{*}{9} & $a$ & 15.3 & 16.2 & 17.4 & 17.8 & 19.5 & 20.3 \\
\hline & b & 15.1 & 16.1 & 17.1 & 18.3 & 19.5 & 20.5 \\
\hline & $\mathrm{c}$ & 15.7 & 16.4 & 17.7 & 18.3 & 19.4 & 20.3 \\
\hline & mean & 15.41 & 16.26 & 17.47 & 18.20 & 19.51 & 20.43 \\
\hline & s.d. & 0.12 & 0.10 & 0.22 & 0.33 & 0.04 & 0.13 \\
\hline \multirow{5}{*}{10} & $\mathrm{a}$ & 15.1 & 15.8 & 17.6 & 18.3 & 19.3 & 18.9 \\
\hline & b & 14.9 & 16.6 & 17.3 & 18.7 & 19.2 & 15.1 \\
\hline & $\mathrm{c}$ & 16.1 & 16.0 & 16.9 & 17.8 & 18.8 & 26.6 \\
\hline & mean & 15.42 & 15.86 & 16.82 & 17.02 & 20.23 & 18.19 \\
\hline & s.d. & 0.10 & 0.65 & 0.12 & 1.56 & 2.67 & 3.69 \\
\hline \multirow{5}{*}{11} & $a$ & 15.3 & 16.5 & 17.3 & 18.2 & 19.4 & 20.2 \\
\hline & b & 15.4 & 16.3 & 17.4 & 18.2 & 19.2 & 20.6 \\
\hline & $\mathrm{c}$ & 15.7 & 16.6 & 17.1 & 18.2 & 19.6 & 20.1 \\
\hline & mean & 15.51 & 16.50 & 17.33 & 18.20 & 19.45 & 20.38 \\
\hline & s.d. & 0.21 & 0.06 & 0.17 & 0.00 & 0.15 & 0.25 \\
\hline \multirow{5}{*}{12} & a & 15.0 & 16.82 & 17.0 & 18.0 & 19.6 & 19.7 \\
\hline & $\mathrm{b}$ & 15.4 & 16.8 & 17.2 & 18.4 & 18.9 & 20.8 \\
\hline & $\mathrm{c}$ & 15.2 & 15.5 & 17.4 & 18.3 & 19.4 & 19.5 \\
\hline & mean & 14.33 & 14.89 & 12.56 & 16.24 & 17.86 & 18.74 \\
\hline & s.d. & 0.24 & 0.18 & 5.03 & 0.50 & 0.02 & 0.19 \\
\hline
\end{tabular}


Table B2. Moisture content of durum wheat stored at $20^{\circ} \mathrm{C}$

\begin{tabular}{|c|c|c|c|c|c|c|c|}
\hline \multicolumn{8}{|c|}{ Initial moisture content $(\% \mathrm{wb})$} \\
\hline $\begin{array}{l}\text { Storage Period } \\
\text { (week) }\end{array}$ & Replicate & 15.0 & 16.0 & 17.0 & 18.0 & 19.0 & 20.0 \\
\hline \multirow{5}{*}{1} & a & 14.6 & 15.1 & 16.3 & 17.3 & 17.7 & 18.7 \\
\hline & $\mathrm{b}$ & 14.5 & 15.4 & 16.3 & 17.3 & 18.3 & 18.6 \\
\hline & c & 14.3 & 15.0 & 16.0 & 17.3 & 17.6 & 18.7 \\
\hline & mean & 14.53 & 15.21 & 16.26 & 18.43 & 17.92 & 18.72 \\
\hline & s.d. & 0.17 & 0.19 & 0.15 & 1.92 & 0.39 & 0.05 \\
\hline \multirow{5}{*}{2} & a & 14.7 & 15.3 & 16.1 & 17.4 & 17.7 & 18.8 \\
\hline & $\mathrm{b}$ & 14.5 & 15.3 & 16.3 & 17.2 & 17.7 & 18.6 \\
\hline & $\mathrm{c}$ & 14.3 & 15.1 & 16.5 & 17.2 & 17.8 & 18.7 \\
\hline & mean & 14.53 & 15.21 & 16.26 & 18.43 & 17.92 & 18.72 \\
\hline & s.d. & 0.17 & 0.19 & 0.15 & 1.92 & 0.39 & 0.05 \\
\hline \multirow{5}{*}{3} & a & 14.4 & 15.0 & 16.2 & 17.2 & 17.7 & 18.5 \\
\hline & b & 14.4 & 15.0 & 16.2 & 17.0 & 17.8 & 18.5 \\
\hline & $\mathrm{c}$ & 14.2 & 15.1 & 16.2 & 17.1 & 17.6 & 18.7 \\
\hline & mean & 14.46 & 15.19 & 16.25 & 17.25 & 17.48 & 18.78 \\
\hline & s.d. & 0.19 & 0.16 & 0.05 & 0.02 & 0.62 & 0.06 \\
\hline \multirow{5}{*}{4} & $a$ & 14.4 & 14.9 & 16.2 & 17.0 & 17.7 & 18.4 \\
\hline & $\mathrm{b}$ & 14.4 & 15.0 & 16.1 & 17.0 & 17.7 & 18.5 \\
\hline & c & 14.1 & 14.9 & 16.2 & 17.0 & 17.4 & 18.3 \\
\hline & mean & 14.32 & 14.98 & 16.23 & 17.06 & 17.64 & 18.45 \\
\hline & s.d. & 0.13 & 0.07 & 0.07 & 0.02 & 0.15 & 0.10 \\
\hline \multirow{5}{*}{5} & a & 14.4 & 14.7 & 15.8 & 16.9 & 17.7 & 18.0 \\
\hline & $b$ & 14.4 & 15.6 & 16.1 & 16.9 & 17.8 & 18.9 \\
\hline & $\mathrm{c}$ & 14.4 & 15.0 & 16.1 & 17.2 & 17.3 & 18.8 \\
\hline & mean & 14.43 & 15.05 & 16.02 & 17.03 & 17.66 & 18.61 \\
\hline & s.d. & 0.04 & 0.07 & 0.17 & 0.16 & 0.28 & 0.53 \\
\hline \multirow{5}{*}{6} & $\mathrm{a}$ & 14.6 & 15.3 & 16.1 & 17.6 & 18.0 & 19.0 \\
\hline & b & 14.7 & 15.3 & 16.7 & 17.7 & 18.1 & 19.2 \\
\hline & $\mathrm{c}$ & 15.3 & 15.4 & 16.9 & 17.7 & 18.2 & 18.7 \\
\hline & mean & 16.13 & 16.65 & 17.71 & 18.59 & 18.98 & 20.08 \\
\hline & s.d. & 0.12 & 0.04 & 0.04 & 0.08 & 0.25 & 0.20 \\
\hline
\end{tabular}




\begin{tabular}{|c|c|c|c|c|c|c|c|}
\hline \multicolumn{8}{|c|}{ Initial moisture content $(\% \mathrm{wb})$} \\
\hline $\begin{array}{l}\text { Storage Period } \\
\text { (week) }\end{array}$ & Replicate & 15.0 & 16.0 & 17.0 & 18.0 & 19.0 & 20.0 \\
\hline \multirow{5}{*}{7} & a & 15.9 & 16.5 & 17.3 & 17.5 & 17.9 & 19.4 \\
\hline & b & 15.8 & 16.7 & 17.4 & 18.1 & 18.2 & 19.3 \\
\hline & $\mathrm{c}$ & 15.6 & 16.3 & 17.2 & 17.6 & 18.8 & 19.2 \\
\hline & mean & 15.80 & 16.35 & 17.31 & 18.37 & 18.35 & 19.34 \\
\hline & s.d. & 0.11 & 0.11 & 0.11 & 0.17 & 0.48 & 0.07 \\
\hline \multirow{5}{*}{8} & a & 16.1 & 16.6 & 17.6 & 18.6 & 18.9 & 19.8 \\
\hline & $\mathrm{b}$ & 16.1 & 16.6 & 17.6 & 18.5 & 18.7 & 19.8 \\
\hline & $\mathrm{c}$ & 16.0 & 16.6 & 17.5 & 18.8 & 18.7 & 19.3 \\
\hline & mean & 16.12 & 16.6 & 17.63 & 18.67 & 18.86 & 19.67 \\
\hline & s.d. & 0.06 & 0.00 & 0.05 & 0.15 & 0.12 & 0.28 \\
\hline \multirow{5}{*}{9} & $a$ & 15.8 & 16.9 & 16.9 & 18.0 & 19.1 & 19.7 \\
\hline & b & 15.8 & 16.3 & 17.3 & 18.2 & 18.6 & 19.4 \\
\hline & $\mathrm{c}$ & 15.8 & 16.8 & 17.3 & 18.1 & 18.0 & 19.0 \\
\hline & mean & 15.80 & 16.24 & 17.21 & 18.13 & 18.65 & 19.41 \\
\hline & s.d. & 0.00 & 0.04 & 0.23 & 0.08 & 0.56 & 0.36 \\
\hline \multirow{5}{*}{10} & a & 15.4 & 16.0 & 17.2 & 18.1 & 18.4 & 19.2 \\
\hline & b & 15.5 & 16.7 & 17.3 & 17.9 & 18.5 & 19.4 \\
\hline & $\mathrm{c}$ & 15.6 & 16.6 & 17.2 & 18.0 & 18.3 & 18.9 \\
\hline & mean & 15.58 & 16.35 & 17.27 & 18.05 & 18.45 & 19.19 \\
\hline & s.d. & 0.09 & 0.11 & 0.08 & 0.10 & 0.09 & 0.26 \\
\hline \multirow{5}{*}{11} & a & 15.2 & 16.7 & 16.9 & 17.6 & 18.4 & 19.3 \\
\hline & b & 17.0 & 16.0 & 17.3 & 18.1 & 18.1 & 19.4 \\
\hline & $\mathrm{c}$ & 15.7 & 16.7 & 17.3 & 18.2 & 18.5 & 19.5 \\
\hline & mean & 16.02 & 16.31 & 17.20 & 18.02 & 18.37 & 19.49 \\
\hline & s.d. & 1.29 & 0.02 & 0.29 & 0.33 & 0.22 & 0.07 \\
\hline \multirow{5}{*}{12} & a & 15.5 & 16.7 & 16.6 & 18.2 & 18.4 & 19.0 \\
\hline & b & 15.8 & 15.4 & 16.5 & 17.5 & 18.0 & 19.7 \\
\hline & $\mathrm{c}$ & 15.5 & 16.0 & 16.9 & 18.5 & 17.6 & 19.1 \\
\hline & mean & 15.66 & 15.77 & 16.67 & 18.12 & 18.07 & 19.33 \\
\hline & s.d. & 0.17 & 8.57 & 0.21 & 0.52 & 0.37 & 0.39 \\
\hline
\end{tabular}


Table B3. Moisture content of durum wheat stored at $30^{\circ} \mathrm{C}$

\begin{tabular}{|c|c|c|c|c|c|c|c|}
\hline \multicolumn{8}{|c|}{ Initial moisture content $(\% \mathrm{wb})$} \\
\hline $\begin{array}{l}\text { Storage Period } \\
\text { (week) }\end{array}$ & Replicate & 15.0 & 16.0 & 17.0 & 18.0 & 19.0 & 20.0 \\
\hline \multirow{5}{*}{1} & a & 14.6 & 15.2 & 16.2 & 17.2 & 17.8 & 18.7 \\
\hline & $\mathrm{b}$ & 14.4 & 15.0 & 16.3 & 17.2 & 17.7 & 18.8 \\
\hline & c & 14.2 & 15.3 & 16.2 & 17.2 & 17.8 & 18.7 \\
\hline & mean & 14.6 & 15.19 & 16.25 & 17.20 & 17.78 & 18.77 \\
\hline & s.d. & 0.19 & 0.16 & 0.05 & 0.00 & 0.06 & 0.06 \\
\hline \multirow{5}{*}{2} & a & 14.4 & 14.9 & 16.4 & 17.3 & 17.4 & 19.2 \\
\hline & $\mathrm{b}$ & 14.5 & 15.2 & 16.4 & 17.3 & 17.8 & 19.0 \\
\hline & $\mathrm{c}$ & 14.4 & 15.2 & 16.3 & 17.3 & 17.9 & 19.7 \\
\hline & mean & 14.48 & 15.14 & 16.42 & 17.30 & 17.7 & 19.35 \\
\hline & s.d. & 0.06 & 0.18 & 0.06 & 0.00 & 0.26 & 0.40 \\
\hline \multirow{5}{*}{3} & a & 14.2 & 15.0 & 16.7 & 17.4 & 18.1 & 19.1 \\
\hline & $\mathrm{b}$ & 14.3 & 15.1 & 16.8 & 17.2 & 18.1 & 19.0 \\
\hline & $\mathrm{c}$ & 14.2 & 15.1 & 16.7 & 17.0 & 18.4 & 18.8 \\
\hline & mean & 14.26 & 15.09 & 16.78 & 17.20 & 18.20 & 18.97 \\
\hline & s.d. & 0.06 & 0.05 & 0.06 & 0.20 & 0.17 & 0.15 \\
\hline \multirow{5}{*}{4} & $\mathrm{a}$ & 14.2 & 15.0 & 16.0 & 17.2 & 18.0 & 19.7 \\
\hline & $b$ & 14.1 & 15.0 & 16.3 & 16.9 & 18.2 & 19.6 \\
\hline & $\mathrm{c}$ & 14.2 & 15.0 & 16.0 & 19.0 & 17.9 & 19.8 \\
\hline & mean & 14.22 & 15.00 & 16.13 & 17.73 & 17.90 & 19.70 \\
\hline & s.d. & 0.04 & 0.00 & 0.15 & 1.12 & 0.80 & 0.10 \\
\hline \multirow{5}{*}{5} & $\mathrm{a}$ & 14.3 & 15.1 & 16.7 & 17.3 & 18.5 & 19.3 \\
\hline & b & 14.3 & 15.2 & 16.4 & 17.6 & 18.3 & 19.2 \\
\hline & $\mathrm{c}$ & 14.2 & 15.0 & 16.1 & 18.0 & 18.7 & 20.1 \\
\hline & mean & 14.29 & 15.14 & 16.78 & 17.63 & 18.5 & 19.53 \\
\hline & s.d. & 0.08 & 0.06 & 0.37 & 0.35 & 0.2 & 0.49 \\
\hline \multirow{5}{*}{6} & $\mathrm{a}$ & 15.7 & 15.3 & 16.8 & 17.4 & 19.6 & 19.9 \\
\hline & b & 12.8 & 15.7 & 16.6 & 17.6 & 18.0 & 19.7 \\
\hline & $\mathrm{c}$ & 15.7 & 15.6 & 16.8 & 18.0 & 18.5 & 18.9 \\
\hline & mean & 14.78 & 15.53 & 16.73 & 17.67 & 18.57 & 19.5 \\
\hline & s.d. & 1.68 & 0.21 & 0.12 & 0.31 & 0.81 & 0.53 \\
\hline
\end{tabular}




\begin{tabular}{|c|c|c|c|c|c|c|c|}
\hline \multicolumn{8}{|c|}{ Initial moisture content $(\% \mathrm{wb})$} \\
\hline $\begin{array}{l}\text { Storage Period } \\
\text { (week) }\end{array}$ & Replicate & 15.0 & 16.0 & 17.0 & 18.0 & 19.0 & 20.0 \\
\hline \multirow{5}{*}{7} & a & 15.3 & 16.1 & 16.7 & 18.2 & 18.9 & 19.3 \\
\hline & $b$ & 15.7 & 16.3 & 17.4 & 17.8 & 19.0 & 20.2 \\
\hline & $\mathrm{c}$ & 15.4 & 15.9 & 17.3 & 18.0 & 18.8 & 20.1 \\
\hline & mean & 15.53 & 16.15 & 17.13 & 18.00 & 18.90 & 19.19 \\
\hline & s.d. & 0.18 & 0.20 & 0.38 & 0.20 & 0.10 & 1.11 \\
\hline \multirow{5}{*}{8} & a & 15.8 & 16.2 & 16.8 & 18.2 & 18.8 & 19.8 \\
\hline & $b$ & 15.9 & 16.4 & 17.5 & 18.1 & 18.7 & 19.9 \\
\hline & $\mathrm{c}$ & 15.6 & 16.5 & 17.9 & 18.2 & 18.7 & 19.8 \\
\hline & mean & 15.77 & 16.37 & 17.4 & 18.17 & 18.73 & 19.83 \\
\hline & s.d. & 0.15 & 0.15 & 0.56 & 0.06 & 0.06 & 0.06 \\
\hline \multirow{5}{*}{9} & $\mathrm{a}$ & 16.0 & 16.2 & 16.9 & 18.0 & 18.3 & 18.8 \\
\hline & b & 15.6 & 15.9 & 18.2 & 18.2 & 19.2 & 20.7 \\
\hline & $\mathrm{c}$ & 15.7 & 16.2 & 18.0 & 19.1 & 19.2 & 19.6 \\
\hline & mean & 15.77 & 16.1 & 17.7 & 18.43 & 18.90 & 19.70 \\
\hline & s.d. & 0.21 & 0.17 & 0.70 & 0.59 & 0.52 & 0.95 \\
\hline \multirow{5}{*}{10} & $\mathrm{a}$ & 15.8 & 15.9 & 17.3 & 18.5 & 18.7 & 18.2 \\
\hline & $\mathrm{b}$ & 15.5 & 16.1 & 17.5 & 18.5 & 19.0 & 19.9 \\
\hline & $\mathrm{c}$ & 15.5 & 16.1 & 18.5 & 18.3 & 19.4 & 21.2 \\
\hline & mean & 15.60 & 16.03 & 17.77 & 18.43 & 19.03 & 19.77 \\
\hline & s.d. & 0.17 & 0.12 & 0.64 & 0.12 & 0.35 & 1.50 \\
\hline \multirow{5}{*}{11} & $a$ & 15.8 & 16.8 & 17.8 & 18.3 & 19.2 & 19.1 \\
\hline & b & 15.5 & 16.0 & 18.0 & 18.7 & 19.0 & 21.7 \\
\hline & $\mathrm{c}$ & 15.5 & 16.0 & 17.3 & 18.4 & 19.6 & 19.5 \\
\hline & mean & 15.60 & 16.27 & 17.7 & 18.45 & 19.27 & 20.1 \\
\hline & s.d. & 0.17 & 0.46 & 0.36 & 0.21 & 0.31 & 1.40 \\
\hline \multirow{5}{*}{12} & a & 15.3 & 15.9 & 16.8 & 18.2 & 18.8 & 19.9 \\
\hline & $b$ & 15.5 & 16.0 & 17.6 & 17.8 & 17.4 & 20.7 \\
\hline & $\mathrm{c}$ & 12.1 & 15.9 & 17.5 & 18.1 & 18.7 & 19.5 \\
\hline & mean & 14.30 & 15.93 & 17.30 & 18.03 & 18.30 & 20.03 \\
\hline & s.d. & 1.20 & 0.06 & 0.44 & 0.21 & 0.78 & 0.61 \\
\hline
\end{tabular}


Table B4. Moisture content of durum wheat stored at $40^{\circ} \mathrm{C}$

\begin{tabular}{|c|c|c|c|c|c|c|c|}
\hline \multicolumn{8}{|c|}{ Initial moisture content $(\% \mathrm{wb})$} \\
\hline $\begin{array}{l}\text { Storage Period } \\
\text { (week) }\end{array}$ & Replicate & 15.0 & 16.0 & 17.0 & 18.0 & 19.0 & 20.0 \\
\hline \multirow{5}{*}{1} & a & 15.0 & 15.8 & 17.2 & 18.5 & 19.8 & 20.6 \\
\hline & b & 15.1 & 15.9 & 16.9 & 18.4 & 18.5 & 20.7 \\
\hline & $\mathrm{c}$ & 14.9 & 15.8 & 17.0 & 18.4 & 18.8 & 20.6 \\
\hline & mean & 15.00 & 15.83 & 17.03 & 18.43 & 19.03 & 20.63 \\
\hline & s.d. & 0.10 & 0.06 & 0.15 & 0.06 & 0.06 & 0.06 \\
\hline \multirow{5}{*}{2} & $\mathrm{a}$ & 14.6 & 15.7 & 16.5 & 17.9 & 17.6 & 20.1 \\
\hline & $\mathrm{b}$ & 14.4 & 15.7 & 16.3 & 17.4 & 19.7 & 20.6 \\
\hline & $\mathrm{c}$ & 14.8 & 15.5 & 16.1 & 17.7 & 18.8 & 20.0 \\
\hline & mean & 14.60 & 15.63 & 16.30 & 17.67 & 18.7 & 20.23 \\
\hline & s.d. & 0.20 & 0.11 & 0.20 & 0.25 & 1.05 & 0.32 \\
\hline \multirow{5}{*}{3} & a & 14.7 & 14.9 & 16.4 & 17.9 & 16.5 & 21.2 \\
\hline & b & 14.8 & 15.3 & 16.1 & 17.6 & 16.5 & 21.1 \\
\hline & $\mathrm{c}$ & 14.3 & 14.6 & 16.3 & 17.5 & 23.7 & 18.9 \\
\hline & mean & 14.60 & 14.93 & 16.27 & 17.67 & 18.90 & 20.40 \\
\hline & s.d. & 0.26 & 0.35 & 0.15 & 1.05 & 4.15 & 1.30 \\
\hline \multirow{5}{*}{4} & a & 13.8 & 15.2 & 16.8 & 16.3 & 19.2 & 20.3 \\
\hline & b & 14.0 & 14.6 & 16.1 & 17.9 & 17.8 & 20.0 \\
\hline & $\mathrm{c}$ & 14.2 & 15.2 & 15.7 & 17.9 & 18.8 & 19.3 \\
\hline & mean & 14.00 & 15.00 & 16.20 & 17.37 & 18.60 & 19.87 \\
\hline & s.d. & 0.20 & 0.34 & 0.56 & 0.92 & 0.72 & 0.51 \\
\hline \multirow{5}{*}{5} & $\mathrm{a}$ & 14.8 & 15.2 & 16.2 & 17.5 & 18.5 & 18.7 \\
\hline & b & 14.4 & 15.2 & 16.1 & 17.3 & 18.5 & 20.7 \\
\hline & $\mathrm{c}$ & 13.7 & 14.8 & 16.2 & 17.4 & 18.4 & 19.5 \\
\hline & mean & 14.30 & 15.07 & 16.17 & 17.40 & 18.47 & 19.63 \\
\hline & s.d. & 0.56 & 0.23 & 0.06 & 0.10 & 0.06 & 1.01 \\
\hline \multirow{5}{*}{6} & a & 14.7 & 15.6 & 15.0 & 16.4 & 18.4 & 19.6 \\
\hline & b & 13.6 & 15.2 & 16.3 & 17.7 & 18.0 & 19.4 \\
\hline & $\mathrm{c}$ & 14.6 & 14.5 & 16.3 & 17.7 & 18.9 & 19.9 \\
\hline & mean & 14.3 & 15.10 & 15.87 & 17.27 & 18.43 & 19.63 \\
\hline & s.d. & 0.61 & 0.56 & 0.75 & 0.75 & 0.44 & 0.25 \\
\hline
\end{tabular}




\begin{tabular}{|c|c|c|c|c|c|c|c|}
\hline \multicolumn{8}{|c|}{ Initial moisture content ( $\% \mathrm{wb})$} \\
\hline $\begin{array}{l}\text { Storage Period } \\
\text { (week) }\end{array}$ & Replicate & 15.0 & 16.0 & 17.0 & 18.0 & 19.0 & 20.0 \\
\hline \multicolumn{8}{|l|}{7} \\
\hline & $\mathrm{a}$ & 14.4 & 14.8 & 15.4 & 15.9 & 16.6 & 20.4 \\
\hline & $\mathrm{b}$ & 14.2 & 14.9 & 15.2 & 17.7 & 15.9 & 19.3 \\
\hline & $\mathrm{c}$ & 14.2 & 14.4 & 15.8 & 17.4 & 23.0 & 19.8 \\
\hline & mean & 14.26 & 14.70 & 15.45 & 17.00 & 18.50 & 19.83 \\
\hline & s.d. & 0.12 & 0.26 & 0.37 & 0.96 & 3.91 & 0.55 \\
\hline \multicolumn{8}{|l|}{8} \\
\hline & a & 14.0 & 14.4 & 15.5 & 17.2 & 16.2 & 18.7 \\
\hline & $\mathrm{b}$ & 14.2 & 14.6 & 15.8 & 17.1 & 16.6 & 20.7 \\
\hline & $\mathrm{c}$ & 13.9 & 14.5 & 16.5 & 17.0 & 20.7 & 19.5 \\
\hline & mean & 14.03 & 14.5 & 15.93 & 17.10 & 17.83 & 19.63 \\
\hline & s.d. & 0.15 & 0.10 & 0.51 & 0.10 & 2.49 & 1.01 \\
\hline \multicolumn{8}{|l|}{9} \\
\hline & a & 13.9 & 14.5 & 16.0 & 16.1 & 16.4 & 19.7 \\
\hline & b & 13.8 & 14.7 & 15.7 & 16.8 & 17.0 & 19.8 \\
\hline & $\mathrm{c}$ & 14.0 & 14.6 & 15.7 & 17.2 & 20.0 & 18.6 \\
\hline & mean & 13.90 & 14.60 & 15.80 & 16.70 & 17.80 & 19.37 \\
\hline & s.d. & 0.10 & 0.10 & 0.17 & 0.56 & 1.93 & 0.67 \\
\hline \multicolumn{8}{|l|}{10} \\
\hline & a & 13.9 & 14.5 & 15.6 & 16.1 & 17.6 & 18.3 \\
\hline & b & 13.8 & 14.8 & 15.4 & 16.0 & 17.5 & 19.7 \\
\hline & $\mathrm{c}$ & 13.8 & 14.4 & 16.0 & 16.4 & 17.5 & 19.8 \\
\hline & mean & 13.83 & 14.57 & 15.67 & 16.17 & 17.53 & 19.27 \\
\hline & s.d. & 0.06 & 0.21 & 0.30 & 0.21 & 0.06 & 0.84 \\
\hline \multicolumn{8}{|l|}{11} \\
\hline & $a$ & 14.0 & 15.3 & 15.5 & 16.6 & 17.5 & 16.6 \\
\hline & $\mathrm{b}$ & 14.6 & 15.1 & 15.4 & 16.5 & 18.0 & 18.7 \\
\hline & $\mathrm{c}$ & 14.3 & 14.9 & 16.4 & 15.9 & 17.5 & 19.4 \\
\hline & mean & 14.30 & 15.10 & 15.77 & 16.33 & 17.67 & 18.23 \\
\hline & s.d. & 0.30 & 0.20 & 0.55 & 0.38 & 0.29 & 1.46 \\
\hline \multicolumn{8}{|l|}{12} \\
\hline & a & 12.7 & 14.5 & 15.1 & 16.3 & 16.5 & 19.0 \\
\hline & $\mathrm{b}$ & 12.9 & 14.7 & 15.1 & 15.4 & 16.4 & 19.0 \\
\hline & $\mathrm{c}$ & 13.0 & 13.4 & 15.4 & 15.7 & 19.5 & 18.7 \\
\hline & mean & 12.87 & 14.20 & 15.20 & 15.80 & 17.47 & 18.90 \\
\hline & s.d. & 0.15 & 0.70 & 0.17 & 0.46 & 1.76 & 0.17 \\
\hline
\end{tabular}


APPENDIX C: Invisible mould data 
Table C1. Microflora of durum wheat stored at $10^{\circ} \mathrm{C}$

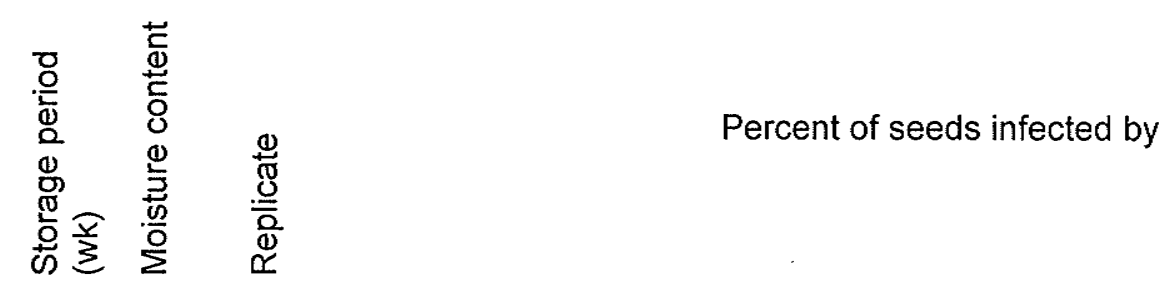

\begin{tabular}{|c|c|c|c|c|c|c|c|c|c|c|c|c|c|}
\hline & & & 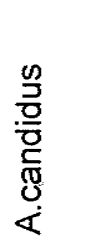 & $\begin{array}{l}\frac{0}{3} \\
\frac{0}{3} \\
\frac{\mathbb{0}}{0} \\
\dot{x}\end{array}$ & 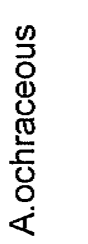 & 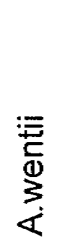 & 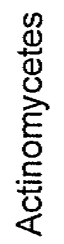 & 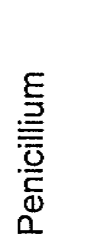 & 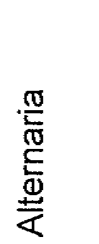 & 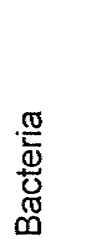 & 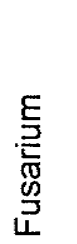 & 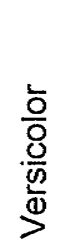 & 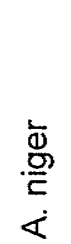 \\
\hline \multirow[t]{18}{*}{2} & 15 & $a$ & 8 & 16 & 4 & & & 44 & 48 & 32 & & & \\
\hline & & b & 4 & & 8 & & & 68 & 36 & 24 & & & \\
\hline & & $\mathrm{c}$ & 8 & 20 & 16 & & & 40 & 44 & 28 & & & \\
\hline & 16 & $a$ & 12 & 8 & 8 & & & 36 & 28 & 44 & & & \\
\hline & & b & 8 & 8 & 4 & & & 28 & 12 & 40 & & & \\
\hline & & $c$ & 12 & 12 & 4 & & & 20 & 8 & 56 & & & \\
\hline & 17 & a & 4 & 12 & 8 & & & 36 & 12 & 36 & & & \\
\hline & & $b$ & 8 & 16 & 12 & & & 32 & 16 & 48 & & & \\
\hline & & $c$ & 4 & 12 & 4 & & & 44 & 4 & 48 & & & \\
\hline & 18 & a & 8 & 4 & 16 & & & 32 & 4 & 48 & & & \\
\hline & & $b$ & & & 4 & & & 8 & & 52 & & & \\
\hline & & c & 0 & 12 & 4 & & & 16 & 8 & 12 & & & \\
\hline & 19 & a & 12 & 24 & 8 & & & 52 & 4 & 32 & 12 & & \\
\hline & & $b$ & & 24 & & & & 60 & 4 & 28 & 8 & & \\
\hline & & c & 16 & 32 & 12 & & & 52 & 4 & 32 & 4 & & \\
\hline & 20 & $a$ & 4 & 16 & 20 & & & 84 & & 36 & 8 & & \\
\hline & & b. & 16 & 12 & 4 & & & 92 & & 32 & & & \\
\hline & & c & 12 & 32 & 8 & & & 76 & 8 & & 4 & & \\
\hline
\end{tabular}




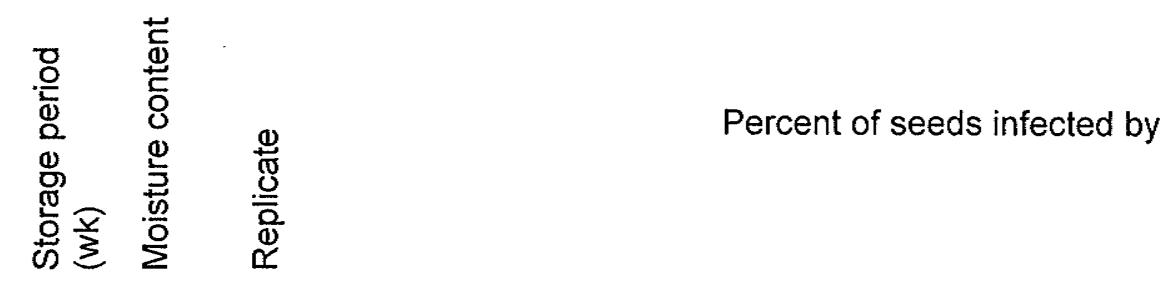

\begin{tabular}{|c|c|c|c|c|c|c|c|c|c|c|c|c|c|}
\hline & & & 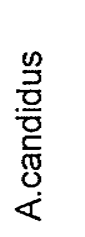 & $\begin{array}{l}\frac{0}{3} \\
\frac{0}{0} \\
\frac{\overrightarrow{0}}{5} \\
\dot{4}\end{array}$ & 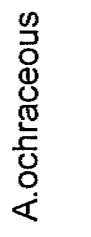 & 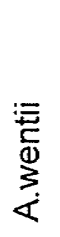 & 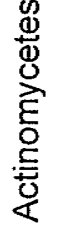 & $\begin{array}{l}\frac{E}{D} \\
\frac{\bar{E}}{\bar{D}} \\
\frac{\bar{D}}{\alpha} \\
\alpha\end{array}$ & 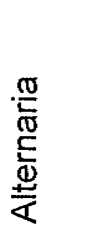 & 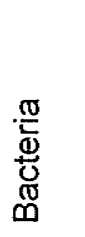 & 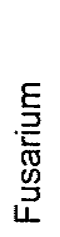 & $\begin{array}{l}\frac{2}{0} \\
\frac{0}{0} \\
\frac{0}{10} \\
\frac{1}{3}\end{array}$ & 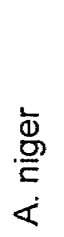 \\
\hline \multirow[t]{18}{*}{4} & 15 & a & & 16 & & & & 12 & & 24 & & & \\
\hline & & b & 4 & 36 & 4 & & & 36 & 12 & 28 & & & \\
\hline & & C & 12 & 12 & & & & 12 & & 28 & & & \\
\hline & 16 & $a$ & & 12 & & & & 20 & & 24 & & & \\
\hline & & $b$ & & 40 & & & & 12 & & 16 & & & \\
\hline & & $c$ & 4 & 24 & 4 & & & 20 & 4 & 16 & & & \\
\hline & 17 & $a$ & 4 & 40 & 4 & & & 48 & & 20 & & & \\
\hline & & b & 20 & 20 & 4 & & & 52 & & & & & \\
\hline & & $c$ & 24 & 40 & 24 & & & 36 & 4 & 12 & & & \\
\hline & 18 & a & 60 & & 8 & & & 68 & & & & & \\
\hline & & b & 64 & & 4 & & & 76 & & 12 & & & \\
\hline & & c & 52 & & & & & 88 & & 16 & & & \\
\hline & 19 & $a$ & 16 & & & & & 80 & & 20 & & & \\
\hline & & $b$ & 36 & & & & & 88 & 4 & & & & \\
\hline & & c & 36 & 8 & 4 & & & 80 & & 16 & & & \\
\hline & 20 & $a$ & 28 & 4 & & & & 60 & & 12 & & & \\
\hline & & b & 16 & 4 & 4 & & & 64 & & 20 & & & \\
\hline & & c & 36 & & 12 & & & 52 & 4 & 12 & & & \\
\hline
\end{tabular}




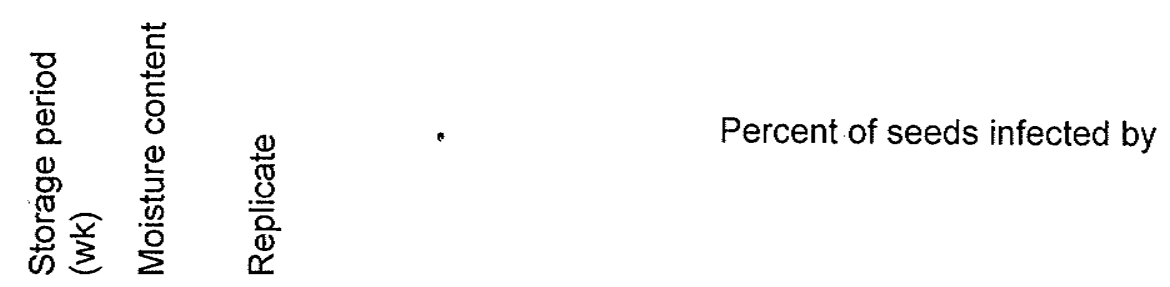

\begin{tabular}{|c|c|c|c|c|c|c|c|c|c|c|c|c|c|}
\hline & & & 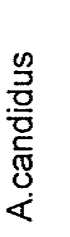 & 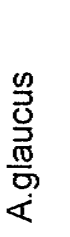 & 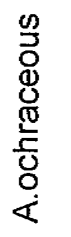 & 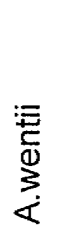 & 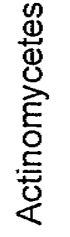 & 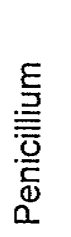 & 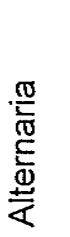 & 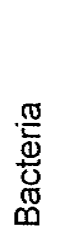 & 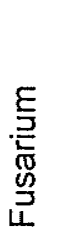 & $\begin{array}{l}\frac{\overline{0}}{0} \\
\frac{0}{0} \\
\frac{0}{0}\end{array}$ & $\begin{array}{l}\text { 高 } \\
\text { 号 } \\
\dot{<}\end{array}$ \\
\hline \multirow[t]{18}{*}{6} & 15 & $a$ & 16 & 16 & 8 & & 8 & 40 & 24 & 48 & 4 & & \\
\hline & & b & 8 & 20 & 4 & & & 16 & 20 & 56 & 4 & 4 & \\
\hline & & $c$ & 8 & 24 & & & 20 & 12 & 24 & 24 & & 8 & 4 \\
\hline & 16 & a & 8 & 16 & 8 & & 16 & 16 & 20 & 24 & & 8 & 4 \\
\hline & & $b$ & 4 & 16 & 8 & & 12 & 36 & 2 & 24 & & 12 & 8 \\
\hline & & $c$ & 4 & 8 & & & 24 & 12 & 28 & 24 & & & \\
\hline & 17 & $a$ & & 32 & 8 & & 20 & 36 & 8 & 20 & & 64 & 4 \\
\hline & & b & 12 & 12 & 4 & & 12 & 20 & 24 & 24 & & & \\
\hline & & c & 4 & 16 & 4 & & 12 & 16 & 4 & 32 & & & \\
\hline & 18 & $a$ & 8 & 28 & & & 8 & 4 & 4 & 28 & & & \\
\hline & & b & & 72 & 4 & & 16 & 8 & 24 & 52 & & 64 & 4 \\
\hline & & c & 8 & 36 & 8 & & 20 & 4 & 12 & 24 & 4 & 64 & 4 \\
\hline & 19 & a & 4 & 16 & 4 & & 12 & 84 & 4 & 4 & & & \\
\hline & & $b$ & & 24 & 12 & & 4 & 84 & 4 & & & & \\
\hline & & c & 8 & 28 & 4 & & 8 & 84 & 8 & 4 & & 4 & \\
\hline & 20 & a & 4 & 12 & 4 & & & 88 & 8 & 20 & & & \\
\hline & & $b$ & & 16 & & & 8 & 80 & & 20 & & & \\
\hline & & $c$ & 4 & 20 & 4 & & 12 & 80 & 4 & 20 & & 8 & \\
\hline
\end{tabular}




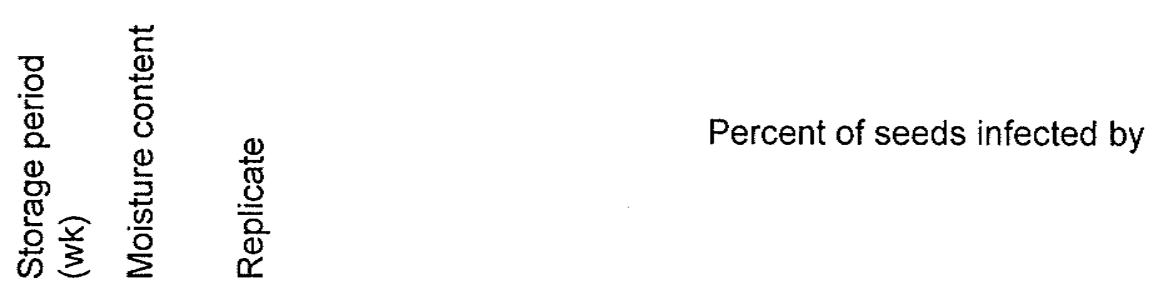

\begin{tabular}{|c|c|c|c|c|c|c|c|c|c|c|c|c|c|}
\hline & & & 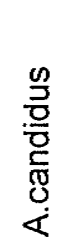 & 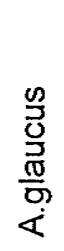 & 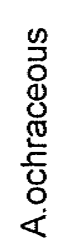 & 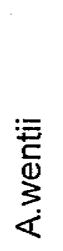 & 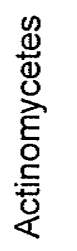 & 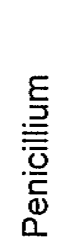 & 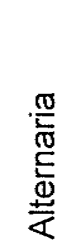 & 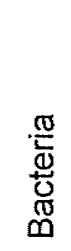 & 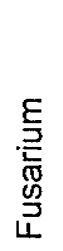 & $\begin{array}{l}\frac{2}{0} \\
\frac{0}{0} \\
\frac{0}{0} \\
\stackrel{0}{>}\end{array}$ & $\begin{array}{l}\stackrel{ }{\mathrm{D}} \\
\stackrel{\mathrm{O}}{\Xi} \\
\dot{<}\end{array}$ \\
\hline \multirow[t]{18}{*}{8} & 15 & a & 52 & 8 & 8 & & 4 & 36 & & & & & \\
\hline & & $b$ & 36 & 16 & 4 & & & 32 & 4 & 12 & & & \\
\hline & & $c$ & 40 & 16 & 8 & & 12 & 40 & & 8 & & & 1 \\
\hline & 16 & a & 32 & 24 & 8 & & 4 & 48 & 4 & & & & \\
\hline & & $b$ & 32 & 16 & 4 & & 12 & 36 & 4 & 8 & & & \\
\hline & & $\mathrm{c}$ & 36 & 8 & 8 & & 8 & 60 & 8 & 4 & & & \\
\hline & 17 & a & 16 & 52 & & & 4 & 28 & & 4 & & & \\
\hline & & $b$ & 12 & 36 & & & & 32 & 8 & 20 & 1 & & 1 \\
\hline & & c & 8 & 44 & 4 & & 8 & 28 & 8 & & 2 & & \\
\hline & 18 & $a$ & 16 & 24 & 8 & & 4 & 48 & & 32 & & & \\
\hline & & $b$ & 32 & 28 & 16 & & & 40 & & 8 & & & \\
\hline & & $c$ & 4 & 48 & & & & 16 & 4 & 4 & & & 1 \\
\hline & 19 & a & 12 & 4 & & & 8 & 72 & & 8 & & & \\
\hline & & b & 12 & 8 & 8 & & & 48 & 4 & 8 & & & \\
\hline & & $c$ & 4 & 4 & 4 & & 4 & 80 & & 12 & & & \\
\hline & 20 & a & 12 & & 4 & & 4 & 76 & & 20 & & & \\
\hline & & $b$ & 20 & 8 & & & & 56 & 8 & 16 & & & \\
\hline & & $c$ & 28 & 8 & 4 & & & 80 & & 20 & & & \\
\hline
\end{tabular}




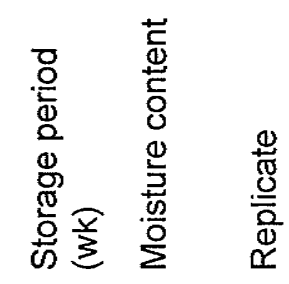

Percent of seeds infected by

\begin{tabular}{|c|c|c|c|c|c|c|c|c|c|c|c|c|c|}
\hline & & & 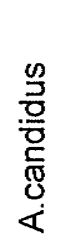 & $\begin{array}{l}\frac{\infty}{3} \\
\frac{0}{3} \\
\frac{\pi}{0} \\
\dot{x}\end{array}$ & 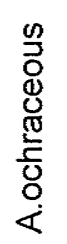 & 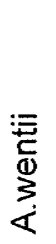 & 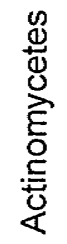 & 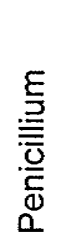 & 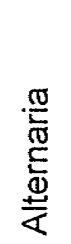 & $\begin{array}{l}\frac{\mathbb{W}}{\mathbb{D}} \\
\frac{\mathbb{J}}{\mathscr{D}} \\
\mathbb{D}\end{array}$ & 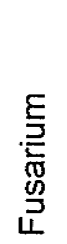 & $\begin{array}{l}\frac{5}{0} \\
\frac{0}{0} \\
\frac{0}{0} \\
>\end{array}$ & 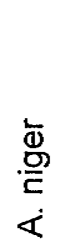 \\
\hline \multirow[t]{18}{*}{10} & 15 & $a$ & 60 & 16 & 8 & & 4 & 44 & & 16 & & & 4 \\
\hline & & $b$ & 44 & 24 & 4 & & & 40 & 4 & 20 & 4 & & \\
\hline & & $c$ & 48 & 24 & 8 & & 12 & 48 & & 16 & & & \\
\hline & 16 & a & 40 & 32 & 8 & & & 56 & 4 & & & & \\
\hline & & $b$ & 40 & 24 & 4 & & 12 & 44 & 4 & 8 & & & 4 \\
\hline & & c & 44 & 16 & 8 & & 8 & 68 & 16 & 12 & 12 & & \\
\hline & 17 & a & 24 & 60 & 12 & & 8 & 36 & & 4 & 16 & & \\
\hline & & $b$ & 20 & 40 & 12 & & 16 & 32 & 8 & 28 & 24 & & \\
\hline & & $c$ & 16 & 56 & 4 & & 8 & 36 & 12 & & 28 & & \\
\hline & 18 & $a$ & 24 & 28 & 8 & & 4 & 56 & & 40 & 4 & & \\
\hline & & $b$ & 40 & 28 & 16 & & & 40 & & 16 & 8 & & \\
\hline & & c & 4 & 72 & 20 & & 8 & 8 & 12 & 12 & & & \\
\hline & 19 & a & 16 & 4 & 16 & & 8 & 80 & & 8 & & & \\
\hline & & b & 16 & 8 & 16 & & & 64 & & 16 & & & \\
\hline & & $\mathrm{c}$ & 4 & 0 & 16 & & 4 & 100 & 8 & 20 & & & \\
\hline & 20 & $a$ & 20 & 0 & 20 & & 4 & 80 & 12 & 20 & 12 & & 4 \\
\hline & & $b$ & 28 & 0 & 16 & & & 60 & 12 & 28 & 4 & & \\
\hline & & $c$ & 36 & 8 & 16 & & & 88 & & 24 & & & \\
\hline
\end{tabular}




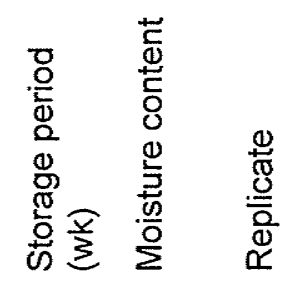

Percent of seeds infected by

\begin{tabular}{|c|c|c|c|c|c|c|c|c|c|c|c|c|c|}
\hline & & & 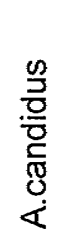 & 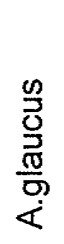 & 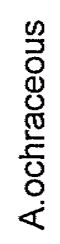 & 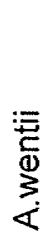 & 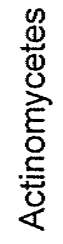 & 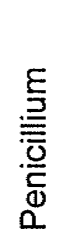 & 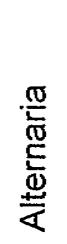 & 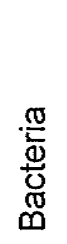 & 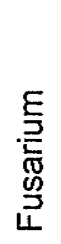 & $\begin{array}{l}\frac{\grave{0}}{0} \\
\frac{.0}{w 0} \\
\frac{\bar{d}}{D}\end{array}$ & 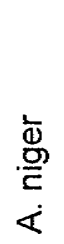 \\
\hline \multirow[t]{18}{*}{12} & 15 & $a$ & 16 & 32 & & & 28 & 20 & 4 & 28 & & & \\
\hline & & $b$ & & 16 & 4 & 4 & & 52 & 8 & 24 & 12 & 4 & 4 \\
\hline & & $c$ & & 32 & & 12 & 4 & 40 & 12 & 36 & & 8 & \\
\hline & 16 & a & 16 & 32 & & 4 & & 36 & 4 & 24 & & 8 & \\
\hline & & b & 16 & 28 & & & & 16 & 16 & 20 & 8 & & \\
\hline & & c & 12 & 32 & & & & 12 & 8 & 24 & 8 & & \\
\hline & 17 & $a$ & 24 & 84 & & & & 8 & 8 & 16 & & & \\
\hline & & $b$ & 12 & 60 & 8 & & & 16 & 8 & 16 & 12 & & \\
\hline & & $c$ & 16 & 64 & 4 & & & 28 & 16 & & 12 & & \\
\hline & 18 & a & 16 & 40 & & & & 40 & & 28 & 4 & & \\
\hline & & $b$ & 20 & 52 & & & & 28 & & 12 & & & \\
\hline & & $c$ & 16 & 40 & & 4 & & 12 & & 8 & & & \\
\hline & 19 & $a$ & 32 & 4 & & & & 84 & & & & & \\
\hline & & $b$ & 56 & 8 & & & & 84 & & 8 & & & \\
\hline & & c & 64 & 4 & & & & 80 & & & & 4 & \\
\hline & 20 & $a$ & 56 & & 4 & & & 56 & 4 & & & & \\
\hline & & $b$ & 24 & & & & & 60 & & 8 & & & \\
\hline & & $c$ & 64 & & & & & 68 & 4 & 20 & & 8 & \\
\hline
\end{tabular}


Table C2. Microflora of durum wheat stored at $20^{\circ} \mathrm{C}$

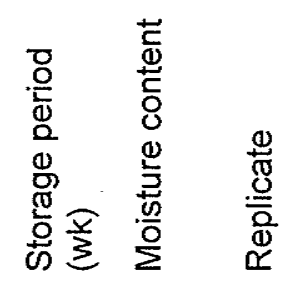

Percent of seeds infected by

\begin{tabular}{|c|c|c|c|c|c|c|c|c|c|c|c|c|c|}
\hline & & & 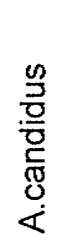 & $\begin{array}{l}\frac{n}{0} \\
\frac{0}{0} \\
\frac{\pi}{0} \\
\dot{x}\end{array}$ & 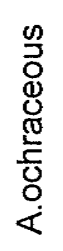 & 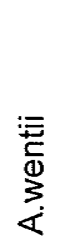 & 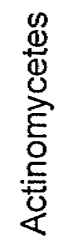 & 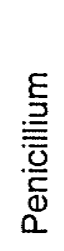 & 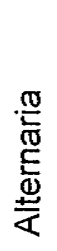 & 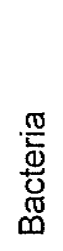 & 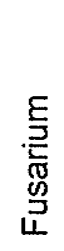 & $\begin{array}{l}\overline{\overline{0}} \\
\frac{0}{0} \\
\frac{0}{0} \\
\stackrel{0}{0} \\
\dot{<}\end{array}$ & 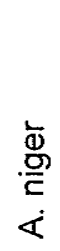 \\
\hline \multirow[t]{18}{*}{2} & 15 & $a$ & 4 & 40 & & & & 12 & & & & & \\
\hline & & $b$ & & 20 & 4 & & & 8 & & & & & \\
\hline & & $c$ & 24 & 16 & 12 & & & 12 & & & & & \\
\hline & 16 & $a$ & 4 & 8 & & & & 16 & & & & & \\
\hline & & $b$ & 4 & 32 & 8 & & & 12 & & & & & \\
\hline & & c & 16 & 8 & 4 & & & 16 & & & 4 & & \\
\hline & 17 & $a$ & 12 & 32 & 8 & & & 16 & & & & & \\
\hline & & $b$ & & 36 & 20 & & 8 & 24 & & & & & \\
\hline & & c & & 44 & 4 & & 12 & 36 & & 4 & & & \\
\hline & 18 & a & 8 & 64 & 36 & & 20 & 40 & & & & & \\
\hline & & b & 8 & 88 & & & 20 & 28 & & 4 & & & \\
\hline & & $c$ & 4 & 76 & 12 & & 16 & 32 & & & 8 & & \\
\hline & 19 & a & 8 & 68 & 20 & & 4 & 32 & & & & & \\
\hline & & b & 12 & 80 & 8 & & 8 & 20 & & & & & \\
\hline & & $c$ & 4 & 84 & 4 & & 20 & 36 & & & & & \\
\hline & 20 & a & 8 & 76 & 20 & & 24 & 32 & & & & & \\
\hline & & $b$ & 4 & 68 & 16 & & 4 & 44 & & & & & \\
\hline & & $c$ & 12 & 76 & 24 & & & 36 & & & & & \\
\hline
\end{tabular}




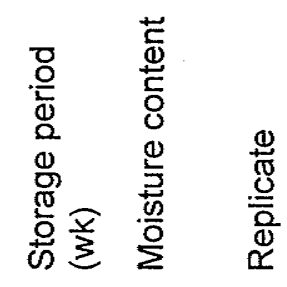

Percent of seeds infected by

\begin{tabular}{|c|c|c|c|c|c|c|c|c|c|c|c|c|c|}
\hline & & & 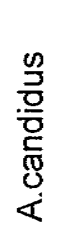 & $\begin{array}{l}\frac{0}{0} \\
\frac{0}{0} \\
\frac{\pi}{0} \\
\dot{x}\end{array}$ & $\begin{array}{l}0 \\
0 \\
0 \\
0 \\
\mathbb{W} \\
\frac{0}{0} \\
0 \\
<\end{array}$ & 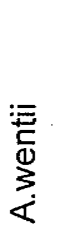 & 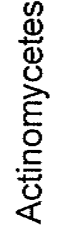 & 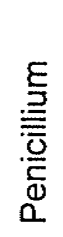 & 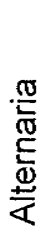 & 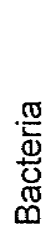 & 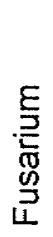 & $\begin{array}{l}\frac{0}{0} \\
\frac{0}{0} \\
\frac{0}{0} \\
0 \\
\end{array}$ & 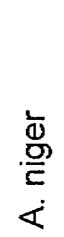 \\
\hline \multirow[t]{18}{*}{4} & 15 & $a$ & 12 & 32 & & & & 12 & & & & & \\
\hline & & b & 16 & 20 & & & & 8 & & & & & \\
\hline & & $c$ & 12 & 12 & 8 & & & 12 & & & & & \\
\hline & 16 & a & 4 & 12 & 4 & & & 8 & & 8 & & & \\
\hline & & $b$ & 8 & 24 & 8 & & & 16 & & 4 & & & \\
\hline & & $c$ & 12 & 20 & 12 & & & 4 & & & & & \\
\hline & 17 & $a$ & 12 & 32 & 4 & & & 16 & & 12 & & & \\
\hline & & b & 20 & 36 & & & & 20 & & 12 & & & \\
\hline & & c & 20 & 44 & & & & 28 & & 8 & & & \\
\hline & 18 & a & 28 & 60 & 4 & & & 36 & & & & & \\
\hline & & b & 24 & 76 & 8 & & & 28 & & 4 & & & \\
\hline & & $c$ & 8 & 80 & 8 & & & 20 & & 8 & & & \\
\hline & 19 & a & 32 & 68 & & & & 24 & & & & & \\
\hline & & b & 24 & 80 & & & & 20 & & 8 & & & \\
\hline & & $c$ & 24 & 84 & 4 & & & 28 & & 12 & & & \\
\hline & 20 & $a$ & 20 & 76 & 12 & & & 24 & & 16 & & & \\
\hline & & b & 4 & 68 & 12 & & & 36 & & & & & \\
\hline & & c & 12 & 76 & 8 & & & 28 & & & & & \\
\hline
\end{tabular}




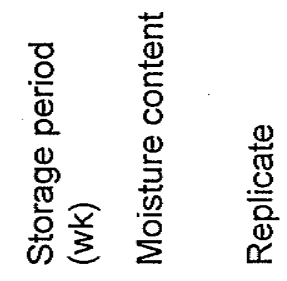

Percent of seeds infected by

\begin{tabular}{|c|c|c|c|c|c|c|c|c|c|c|c|c|c|}
\hline & . & & $\begin{array}{l}\frac{0}{7} \\
\frac{0}{0} \\
\frac{0}{D} \\
\mathbb{8} \\
<\end{array}$ & $\begin{array}{l}\frac{0}{0} \\
\frac{0}{0} \\
\frac{\pi}{0} \\
\dot{4}\end{array}$ & 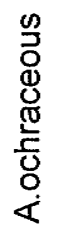 & $\begin{array}{l}: \overline{\bar{c}} \\
\overline{0} \\
3 \\
\dot{\alpha}\end{array}$ & 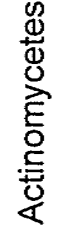 & 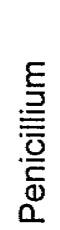 & 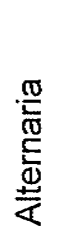 & 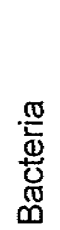 & 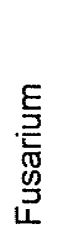 & $\begin{array}{l}\frac{0}{0} \\
\frac{.0}{0} \\
\frac{2}{2} \\
\frac{4}{4}\end{array}$ & 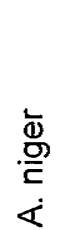 \\
\hline \multirow[t]{18}{*}{6} & 15 & a & 12 & 28 & 4 & & & 12 & & 28 & 4 & & \\
\hline & & $b$ & 8 & 20 & 4 & & & 24 & & 20 & & & \\
\hline & & c & 12 & 16 & & & & 12 & & 20 & & & \\
\hline & 16 & a & 12 & 36 & 4 & & & 8 & & 4 & & & 12 \\
\hline & & b & & 8 & & & & & & 4 & & & \\
\hline & & $c$ & & 4 & & & 4 & & & & & & \\
\hline & 17 & $a$ & 56 & 40 & & & 4 & 64 & 8 & 40 & & & 8 \\
\hline & & $b$ & 40 & 36 & & & 4 & 52 & & 20 & & & 8 \\
\hline & & c & 44 & 36 & 20 & & & 52 & 8 & 28 & & & 8 \\
\hline & 18 & $a$ & 24 & 28 & 20 & & & 76 & & 8 & & & \\
\hline & & b & 20 & 16 & 4 & & 8 & 72 & & 12 & & & \\
\hline & & c & 20 & 12 & 16 & & & 68 & & 32 & & & \\
\hline & 19 & a & 20 & 16 & 24 & & & 68 & 4 & 20 & & & \\
\hline & & b & 0 & 16 & 20 & & & 96 & & 12 & & & \\
\hline & & c & 12 & 8 & & & & 80 & & 16 & & & \\
\hline & 20 & $a$ & 12 & 4 & 8 & & & 80 & 4 & 4 & & & \\
\hline & & b & 8 & 12 & 16 & & & 84 & & 8 & & & \\
\hline & & c & 8 & 16 & 20 & & & 72 & 12 & & & & \\
\hline
\end{tabular}




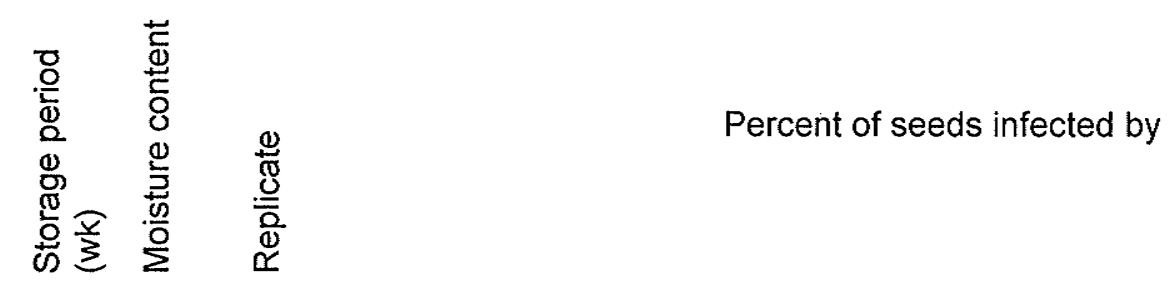

\begin{tabular}{|c|c|c|c|c|c|c|c|c|c|c|c|c|c|}
\hline & & & 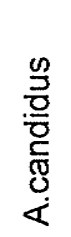 & $\begin{array}{l}\stackrel{0}{0} \\
\frac{0}{\mathbb{\pi}} \\
\frac{\pi}{0} \\
\dot{<}\end{array}$ & 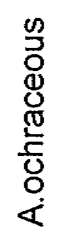 & 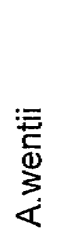 & 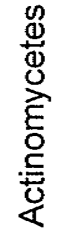 & 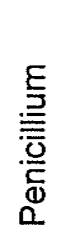 & 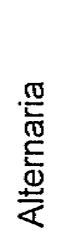 & 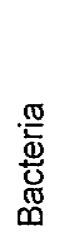 & 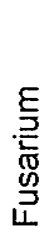 & 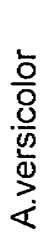 & 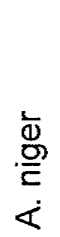 \\
\hline \multirow[t]{18}{*}{8} & \multirow[t]{3}{*}{15} & $a$ & 4 & 32 & 4 & & & 12 & & 8 & & & \\
\hline & & $b$ & 8 & 36 & & & & 8 & & 4 & & & \\
\hline & & $c$ & & 28 & 8 & & & 20 & & 8 & & & \\
\hline & \multirow[t]{3}{*}{16} & $a$ & 12 & 16 & & & & 20 & 4 & 20 & & & \\
\hline & & $b$ & 8 & 36 & & & 8 & 28 & & 12 & & & \\
\hline & & $c$ & 12 & 40 & 8 & & 4 & 24 & & 4 & & & \\
\hline & \multirow[t]{3}{*}{17} & a & 8 & 24 & & & 4 & 32 & & 8 & & & \\
\hline & & $b$ & 12 & 20 & 4 & & & 24 & & 4 & & & \\
\hline & & $c$ & 20 & 28 & 4 & & & 36 & 4 & 12 & & & \\
\hline & \multirow[t]{3}{*}{18} & a & 32 & 16 & & & 4 & 56 & & & & & \\
\hline & & $b$ & 36 & 12 & & & & 36 & & 8 & & & \\
\hline & & $c$ & 48 & 16 & & & & 52 & 8 & & & & \\
\hline & \multirow[t]{3}{*}{19} & $a$ & 20 & 20 & & & 8 & 36 & 12 & 4 & & & \\
\hline & & $b$ & 36 & 12 & 8 & & 12 & 32 & & 8 & & & \\
\hline & & $c$ & 24 & 16 & & & & 52 & & 4 & & & \\
\hline & \multirow[t]{3}{*}{20} & a & 28 & 32 & & & & 48 & & 4 & & & \\
\hline & & $b$ & 16 & 20 & 4 & & & 36 & & 8 & & & \\
\hline & & $c$ & 20 & 12 & & & & 32 & & & & & \\
\hline
\end{tabular}




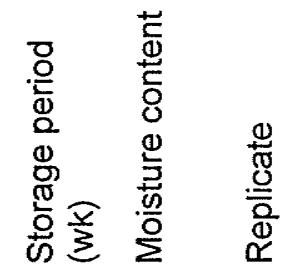

Percent of seeds infected by

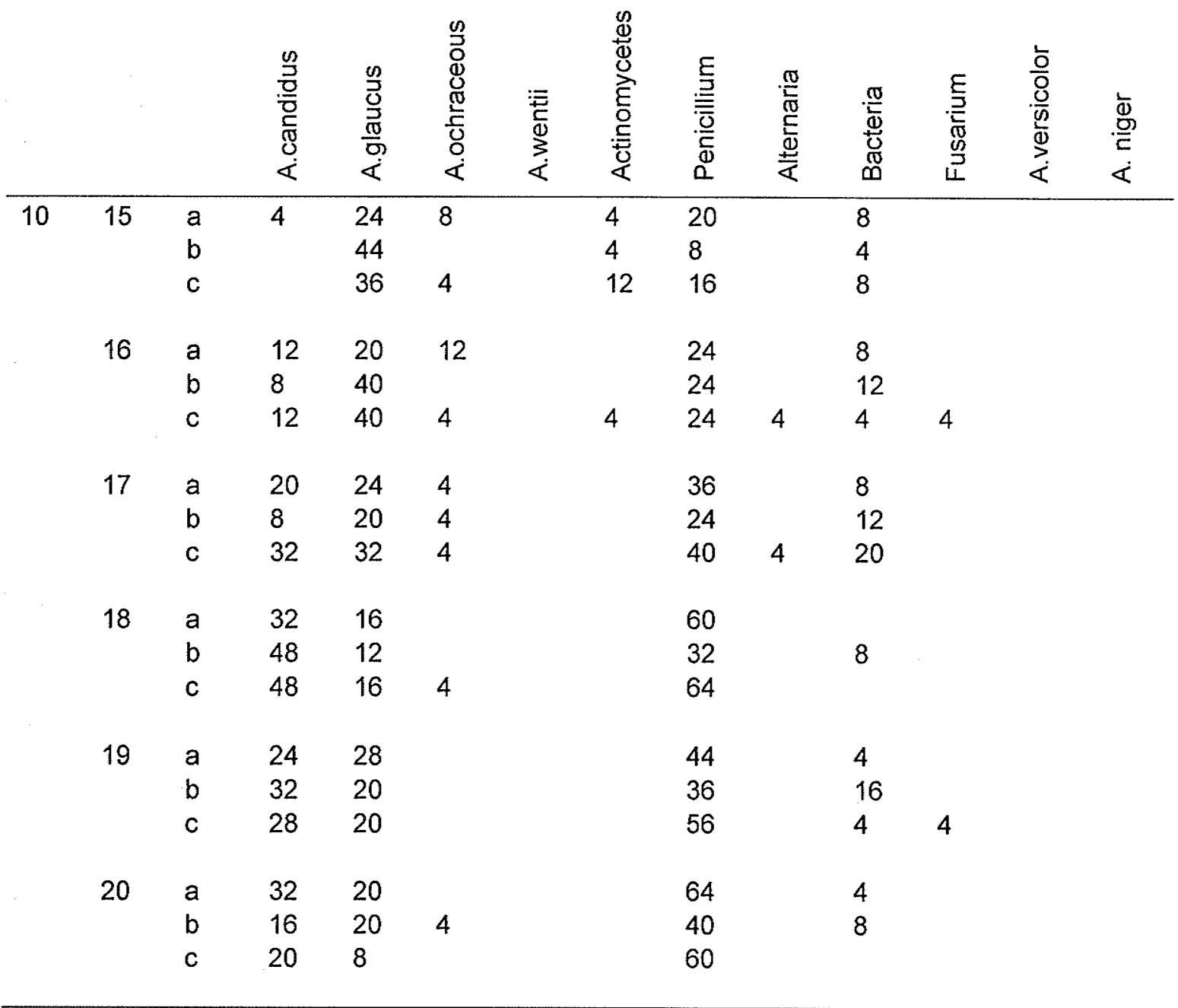




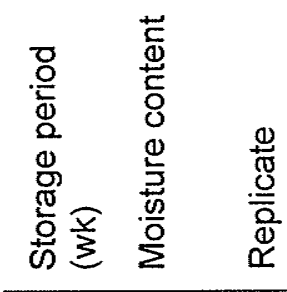

Percent of seeds infected by

\begin{tabular}{|c|c|c|c|c|c|c|c|c|c|c|c|c|c|}
\hline & & & 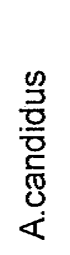 & $\begin{array}{l}\frac{0}{3} \\
\frac{0}{\pi} \\
\frac{\pi}{\square}\end{array}$ & 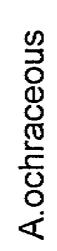 & 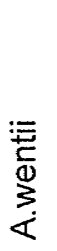 & 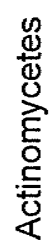 & $\begin{array}{l}\frac{E}{D} \\
\frac{\overline{\bar{D}}}{\bar{D}} \\
\frac{\mathrm{D}}{2} \\
\end{array}$ & 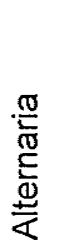 & 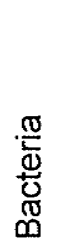 & 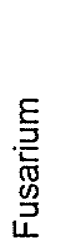 & $\begin{array}{l}\frac{1}{0} \\
\frac{.0}{0} \\
\frac{0}{0} \\
\frac{0}{4}\end{array}$ & 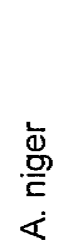 \\
\hline \multirow[t]{18}{*}{12} & 15 & a & 32 & 12 & 24 & & & 40 & & & & & 8 \\
\hline & & $b$ & 16 & 16 & & & 4 & 36 & & & & & 16 \\
\hline & & $c$ & 36 & 32 & 12 & & 4 & 56 & & & & & \\
\hline & 16 & a & 20 & 8 & 4 & & & 60 & & 4 & & & \\
\hline & & $b$ & 28 & 4 & & & & 76 & & & & & 8 \\
\hline & & $c$ & 4 & & & & & 64 & & 12 & & & \\
\hline & 17 & a & 52 & 20 & & & & 80 & & & & & \\
\hline & & $b$ & 68 & 12 & & & & 56 & & & & & \\
\hline & & c & 64 & 8 & 4 & & & 40 & & & & & \\
\hline & 18 & $a$ & 64 & 8 & & & & 72 & & & & & \\
\hline & & b & 44 & 4 & 4 & & 4 & 80 & & & & & \\
\hline & & c & 32 & 28 & & & 4 & 72 & & & & & \\
\hline & 19 & $a$ & 44 & 16 & & & 4 & 64 & & & & & \\
\hline & & $b$ & 28 & 16 & & & & 68 & & & & & \\
\hline & & $\mathrm{c}$ & 44 & 8 & & & & 80 & & & & & \\
\hline & 20 & $a$ & 24 & 20 & & & 8 & 76 & & & & & \\
\hline & & $b$ & 12 & 4 & 4 & & & 68 & & & & & \\
\hline & & c & 36 & 12 & & & 8 & 64 & & & & & \\
\hline
\end{tabular}


TableC3. Microflora of durum wheat stored at $30^{\circ} \mathrm{C}$

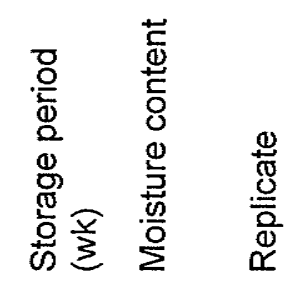

Percent of seeds infected by

\begin{tabular}{|c|c|c|c|c|c|c|c|c|c|c|c|c|c|}
\hline & & & 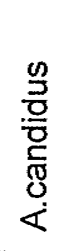 & $\begin{array}{l}\stackrel{0}{\overrightarrow{0}} \\
\stackrel{0}{0} \\
\frac{\pi}{\sigma} \\
\dot{\alpha}\end{array}$ & 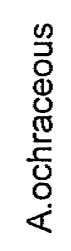 & 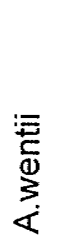 & 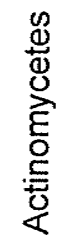 & 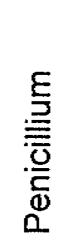 & 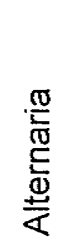 & 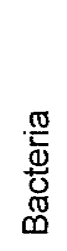 & 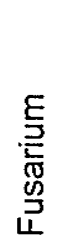 & $\begin{array}{l}\frac{5}{0} \\
\frac{.0}{0} \\
\frac{5}{0} \\
\frac{8}{<}\end{array}$ & 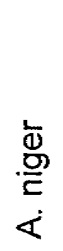 \\
\hline \multirow[t]{18}{*}{2} & 15 & a & 8 & 36 & 4 & & & 12 & & & & & \\
\hline & & b & 4 & 12 & 8 & & 8 & 20 & & 8 & & & \\
\hline & & c & 12 & 20 & 4 & & & 12 & 4 & & & & \\
\hline & 16 & a & 4 & 16 & & & 4 & 8 & & 4 & 4 & & \\
\hline & & $b$ & 8 & 32 & 8 & & 12 & 12 & 8 & & & & \\
\hline & & $c$ & 16 & 8 & 4 & & 8 & 16 & & 4 & & & \\
\hline & 17 & a & 12 & 40 & 8 & & 8 & 16 & & & & & \\
\hline & & $b$ & 4 & 36 & 20 & & 4 & 32 & & 4 & 2 & & \\
\hline & & $c$ & & 44 & 4 & & & 36 & & 4 & & & \\
\hline & 18 & $a$ & 12 & 68 & 16 & & & 36 & & & & & \\
\hline & & b & 8 & 88 & & & & 28 & & 4 & & & \\
\hline & & $c$ & 8 & 76 & & & 4 & 32 & 4 & & & & \\
\hline & 19 & $a$ & 16 & 76 & 4 & & 4 & 32 & & 20 & & & \\
\hline & & $b$ & 12 & 80 & 8 & & 4 & 20 & 4 & 16 & 4 & & \\
\hline & & $\mathrm{c}$ & 4 & 84 & 4 & & & 40 & 8 & & & & \\
\hline & 20 & $a$ & 8 & 84 & & & 8 & 32 & & 12 & & & \\
\hline & & b & 4 & 68 & 16 & & 4 & 44 & & 4 & & & \\
\hline & & $c$ & 12 & 76 & 12 & & & 36 & & & & & \\
\hline
\end{tabular}




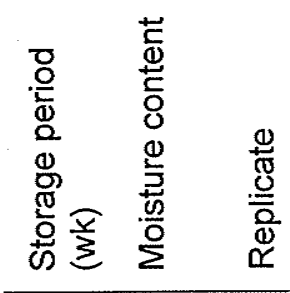

Percent of seeds infected by

\begin{tabular}{|c|c|c|c|c|c|c|c|c|c|c|c|c|c|}
\hline & & & 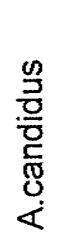 & $\begin{array}{l}\text { 号 } \\
\mathrm{O} \\
\frac{\overrightarrow{0}}{0} \\
\dot{<}\end{array}$ & $\begin{array}{l}\frac{0}{3} \\
\overline{0} \\
\frac{d}{0} \\
\frac{\pi}{5} \\
\frac{0}{8} \\
\dot{\alpha}\end{array}$ & 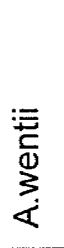 & 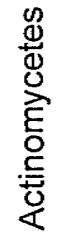 & 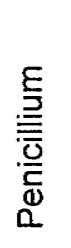 & 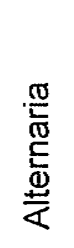 & 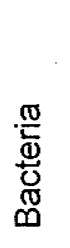 & 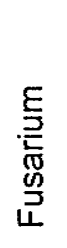 & $\begin{array}{l}\frac{\overline{0}}{0} \\
\frac{0}{0} \\
\frac{0}{0} \\
\bar{\alpha} \\
\alpha\end{array}$ & 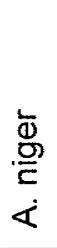 \\
\hline \multirow[t]{18}{*}{4} & 15 & $a$ & 16 & 36 & 4 & & 4 & 16 & & & & & \\
\hline & & $b$ & 20 & 12 & 8 & & 4 & 24 & & 8 & & & \\
\hline & & $c$ & 16 & 20 & 4 & & & 20 & 4 & & & & \\
\hline & 16 & a & 12 & 16 & & & & 16 & & 4 & 4 & & \\
\hline & & $b$ & 20 & 32 & 8 & & 8 & 28 & 8 & & 8 & & \\
\hline & & $c$ & 24 & 8 & 4 & & 12 & 8 & & 4 & & & \\
\hline & 17 & a & 28 & 28 & 8 & & 20 & 12 & & & & & \\
\hline & & b & 20 & 36 & 20 & & 20 & 20 & & 4 & 4 & & \\
\hline & & c & 8 & 20 & 4 & & 16 & 20 & & 4 & & & \\
\hline & 18 & a & 12 & 24 & 16 & & & 60 & & & & & \\
\hline & & b & 16 & 28 & & & 8 & 48 & & 4 & & & \\
\hline & & c & 20 & 36 & & & 12 & 56 & 4 & & & & \\
\hline & 19 & $a$ & 16 & 36 & 4 & & 12 & 44 & & 20 & & & \\
\hline & & b & 12 & 20 & 8 & & 4 & 52 & 4 & 16 & 4 & & \\
\hline & & c & 28 & 44 & 4 & & 8 & 56 & 8 & & & & \\
\hline & 20 & $a$ & 12 & 48 & & & 8 & 60 & & 12 & & & \\
\hline & & b & 20 & 68 & 16 & & 8 & 44 & & 4 & & & \\
\hline & & c & 12 & 60 & 12 & & 8 & 52 & & & & & \\
\hline
\end{tabular}




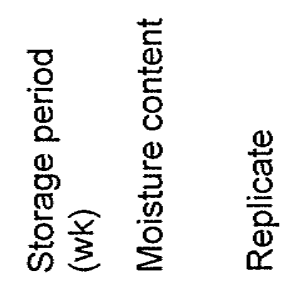

Percent of seeds infected by

\begin{tabular}{|c|c|c|c|c|c|c|c|c|c|c|c|c|c|}
\hline & & & 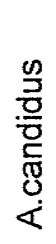 & $\begin{array}{l}\frac{0}{0} \\
\frac{0}{0} \\
\frac{0}{5} \\
\dot{\alpha}\end{array}$ & 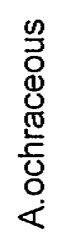 & 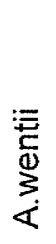 & 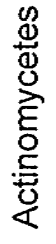 & 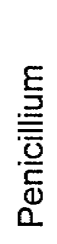 & 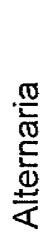 & $\begin{array}{l}\frac{\mathbb{W}}{\mathbb{d}} \\
\frac{\mathbb{d}}{\mathbb{D}} \\
\infty\end{array}$ & 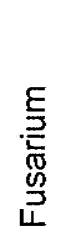 & $\begin{array}{l}\frac{\overline{0}}{0} \\
\frac{0}{00} \\
\frac{5}{0} \\
\dot{\alpha}\end{array}$ & 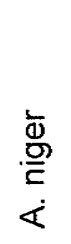 \\
\hline \multirow[t]{18}{*}{6} & 15 & a & 28 & 24 & 8 & & & 32 & 12 & 32 & & & \\
\hline & & b & 24 & 20 & 12 & & & 52 & & 44 & & & \\
\hline & & c & 16 & 44 & 12 & & & 60 & 4 & 60 & 8 & & \\
\hline & 16 & $a$ & 36 & 40 & 8 & & & 72 & 4 & 84 & & & \\
\hline & & $b$ & 20 & 36 & 4 & & & 64 & & 44 & & & \\
\hline & & C & 20 & 24 & 4 & & & 40 & & 52 & & & \\
\hline & 17 & $a$ & 12 & 16 & & & & 68 & & 24 & & & \\
\hline & & $b$ & 24 & 36 & & & & 84 & & 36 & & & \\
\hline & & $\mathrm{c}$ & 24 & 32 & 8 & & & 92 & & 28 & & & \\
\hline & 18 & $a$ & 32 & 36 & 12 & & & 92 & & 8 & 4 & & \\
\hline & & $b$ & 28 & 28 & 16 & & & 92 & & 12 & & & \\
\hline & & c & 44 & 20 & 8 & & & 80 & & 16 & & & \\
\hline & 19 & a & 20 & 16 & 20 & & & 80 & & 12 & 4 & & \\
\hline & & b & 12 & 20 & 20 & & & 64 & & 48 & & & \\
\hline & & c & 16 & 20 & 12 & & & 60 & & 32 & & & \\
\hline & 20 & $a$ & 24 & 16 & 20 & & & 40 & & 32 & & & \\
\hline & & $b$ & 20 & 24 & 20 & & & 36 & & 40 & & & \\
\hline & & c & 8 & 12 & 16 & & & 36 & & 48 & & & \\
\hline
\end{tabular}




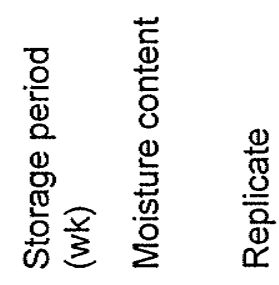

Percent of seeds infected by

\begin{tabular}{|c|c|c|c|c|c|c|c|c|c|c|c|c|c|}
\hline & & & 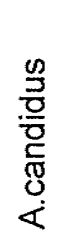 & 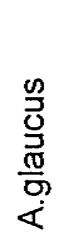 & 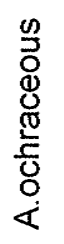 & 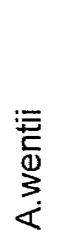 & 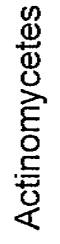 & 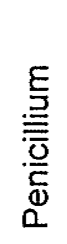 & 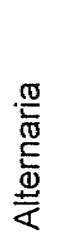 & 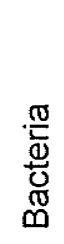 & 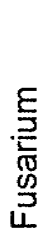 & 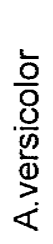 & $\begin{array}{l}\stackrel{\grave{\Phi}}{.} \\
\text { 品 } \\
\dot{<}\end{array}$ \\
\hline \multirow[t]{18}{*}{8} & 15 & $a$ & 36 & 24 & & & & 64 & & & & & \\
\hline & & $b$ & 28 & 28 & & & & 40 & & 4 & & & \\
\hline & & $c$ & 24 & 32 & & & & 48 & & & & & \\
\hline & 16 & $a$ & 28 & 24 & & & & 36 & & 8 & & & \\
\hline & & b & 20 & 32 & & & & 52 & & & & & \\
\hline & & c & 8 & 44 & & & & 60 & & & & & \\
\hline & 17 & a & 40 & 8 & & & . & 68 & & & & & \\
\hline & & $b$ & 36 & 16 & 12 & & & 44 & & & & & \\
\hline & & c & 20 & 12 & & & & 56 & & & & & \\
\hline & 18 & $a$ & 28 & 40 & 4 & & & 72 & & & & & \\
\hline & & b & 32 & 32 & & & & 56 & & & & & \\
\hline & & c & 36 & 20 & 4 & & & 48 & & & & & \\
\hline & 19 & $a$ & 8 & 44 & 4 & & & 44 & & 4 & & & \\
\hline & & b & 20 & 40 & 8 & & & 72 & & & & & \\
\hline & & c & 16 & 32 & & & & 80 & & & & & \\
\hline & 20 & a & 12 & 16 & 4 & & & 68 & & 4 & & & \\
\hline & & b & 20 & 36 & & & & 64 & & & & & \\
\hline & & c & 28 & 28 & 4 & & & 68 & & & & & \\
\hline
\end{tabular}




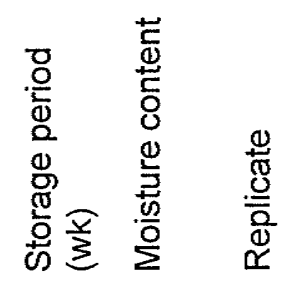

Percent of seeds infected by

\begin{tabular}{|c|c|c|c|c|c|c|c|c|c|c|c|c|c|}
\hline & & & 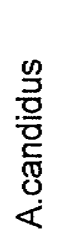 & $\begin{array}{l}\frac{\omega}{0} \\
\frac{0}{0} \\
\frac{\omega}{0} \\
\dot{x}\end{array}$ & 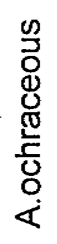 & 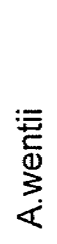 & 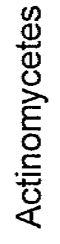 & 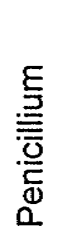 & 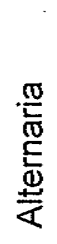 & 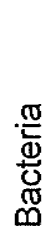 & 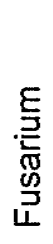 & $\begin{array}{l}\frac{5}{0} \\
\frac{0}{0} \\
\frac{0}{0} \\
2 \\
<\end{array}$ & 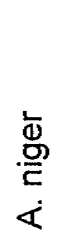 \\
\hline \multirow[t]{18}{*}{10} & 15 & a & 44 & 24 & & & & 64 & & & & & \\
\hline & & $b$ & 28 & 28 & & & & 40 & & 4 & & & \\
\hline & & $c$ & 32 & 32 & & & & 48 & & & & & \\
\hline & 16 & $a$ & 20 & 24 & & & & 36 & & 8 & & & \\
\hline & & b & 20 & 32 & & & & 52 & & & & & \\
\hline & & $c$ & 8 & 44 & & & & 60 & & & & & \\
\hline & 17 & $a$ & 44 & 8 & & & & 68 & & & & & \\
\hline & & b & 40 & 16 & 12 & & & 44 & & & & & \\
\hline & & c & 20 & 12 & & & & 56 & & & & & \\
\hline & 18 & $a$ & 32 & 40 & 4 & & & 72 & & & & & \\
\hline & & $b$ & 32 & 32 & & & & 56 & & & & & \\
\hline & & $c$ & 44 & 20 & 4 & & & 48 & & & & & \\
\hline & 19 & $a$ & 4 & 44 & 4 & & & 44 & & 4 & & & \\
\hline & & b & 32 & 40 & 8 & & & 72 & & & & & \\
\hline & & $c$ & 16 & 32 & & & & 80 & & & & & \\
\hline & 20 & a & 12 & 16 & 4 & & & 68 & & 4 & & & \\
\hline & & b & 32 & 36 & & & & 64 & & & & & \\
\hline & & $c$ & 28 & 28 & 4 & & & 60 & & & & & \\
\hline
\end{tabular}




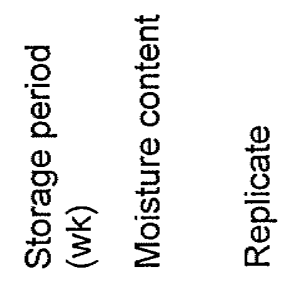

Percent of seeds infected by

\begin{tabular}{|c|c|c|c|c|c|c|c|c|c|c|c|c|c|}
\hline & & & 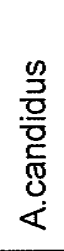 & 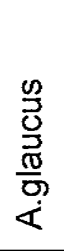 & $\begin{array}{l}0 \\
0 \\
0 \\
\mathbb{d} \\
0 \\
\mathbb{0} \\
\frac{1}{0} \\
0 \\
\end{array}$ & 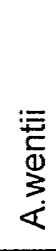 & 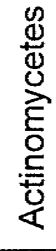 & 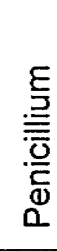 & 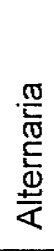 & 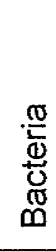 & 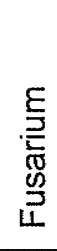 & $\begin{array}{l}\frac{\overline{0}}{0} \\
\frac{0}{0} \\
\bar{\phi} \\
\bar{\alpha} \\
\bar{\alpha}\end{array}$ & 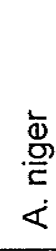 \\
\hline \multirow[t]{18}{*}{12} & 15 & a & 44 & 24 & & & 8 & 68 & & & & & \\
\hline & & $b$ & 44 & 20 & 4 & & & 52 & & 8 & & & 4 \\
\hline & & $\mathrm{c}$ & 44 & 28 & & & & 64 & & & & & 8 \\
\hline & 16 & $a$ & 24 & 36 & & & 8 & 68 & & 16 & & & \\
\hline & & b & 24 & 16 & & & & 68 & & & & & 16 \\
\hline & & c & 36 & 24 & & & 12 & 68 & & 8 & & & \\
\hline & 17 & a & 36 & 64 & & & 24 & 48 & & & & & 8 \\
\hline & & $b$ & 16 & 60 & & & 20 & 40 & & 12 & & & \\
\hline & & c & 16 & 64 & & & 24 & 32 & & 8 & & & \\
\hline & 18 & $a$ & 32 & 72 & 16 & & 32 & 40 & & 4 & & & \\
\hline & & $b$ & 12 & 64 & & & 24 & 40 & & & & & 8 \\
\hline & & $\mathrm{c}$ & 40 & 64 & 4 & & 24 & 56 & & 8 & & & 4 \\
\hline & 19 & $a$ & 40 & 60 & 16 & & 20 & 64 & & 4 & & & \\
\hline & & $b$ & 36 & 68 & 8 & & 28 & 48 & & & & & 8 \\
\hline & & $\mathrm{c}$ & 32 & 88 & & & 8 & 48 & & 8 & & & \\
\hline & 20 & $a$ & 56 & 84 & & & 4 & 80 & & 8 & & & \\
\hline & & $\mathrm{b}$ & 52 & 80 & 4 & & & 76 & & & & & 4 \\
\hline & & $c$ & 44 & 84 & & & 8 & 68 & & & & & \\
\hline
\end{tabular}


TableC4. Microflora of durum wheat stored at $40^{\circ} \mathrm{C}$

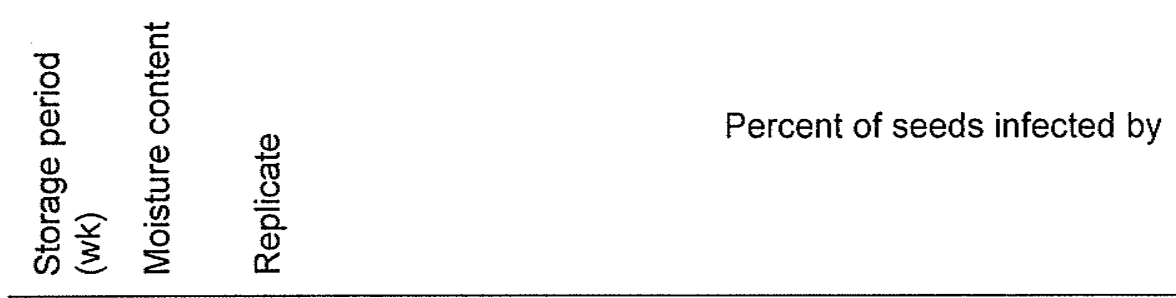

\begin{tabular}{|c|c|c|c|c|c|c|c|c|c|c|c|c|c|}
\hline & & & 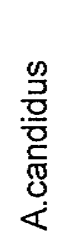 & $\begin{array}{l}\frac{0}{3} \\
\frac{0}{\tilde{\omega}} \\
\frac{\pi}{\sigma} \\
\dot{<}\end{array}$ & 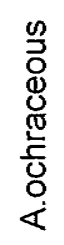 & 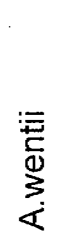 & 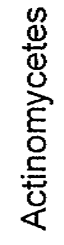 & 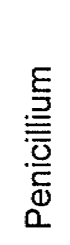 & $\begin{array}{l}\stackrel{\mathbb{W}}{\mathbb{W}} \\
\stackrel{\mathbb{W}}{\mathbb{N}} \\
\frac{\mathbb{J}}{\mathbb{U}}\end{array}$ & 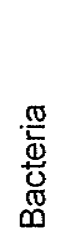 & 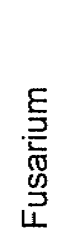 & 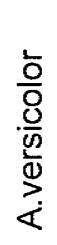 & 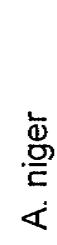 \\
\hline \multirow[t]{18}{*}{2} & 15 & $a$ & 4 & 88 & 32 & & & 16 & & 20 & & & 8 \\
\hline & & b & & 96 & 36 & & & 12 & 4 & 28 & & & \\
\hline & & c & & 80 & 24 & & & 8 & & 8 & & & \\
\hline & 16 & a & 4 & 32 & 36 & & & 48 & & 40 & & & \\
\hline & & $b$ & 8 & 44 & 40 & & & 32 & & 28 & & & \\
\hline & & $c$ & 4 & 48 & 8 & & & 32 & & 40 & & & \\
\hline & 17 & a & 40 & 40 & 20 & & & 32 & & 32 & & & \\
\hline & & b & 56 & 36 & 8 & & & 24 & & 32 & & & \\
\hline & & $c$ & 28 & 44 & 28 & & & 40 & & 32 & & & \\
\hline & 18 & a & 64 & 12 & 8 & & & 24 & & 12 & & & \\
\hline & & b & 56 & 8 & 8 & & & 12 & & 12 & & & \\
\hline & & $c$ & 72 & & 4 & & & 36 & & 44 & & & \\
\hline & 19 & $a$ & 68 & 20 & 12 & & & 24 & & 48 & & & \\
\hline & & $\mathrm{b}$ & 56 & 12 & 20 & & & 40 & & 52 & & & \\
\hline & & $c$ & 56 & 20 & 8 & & & 24 & & 36 & & & \\
\hline & 20 & $a$ & 20 & 8 & 8 & & & 24 & 12 & 24 & & & \\
\hline & & b & 32 & 16 & 48 & & & 28 & 16 & 32 & & & \\
\hline & & c & 24 & 16 & 48 & & & 20 & 28 & 32 & & & \\
\hline
\end{tabular}




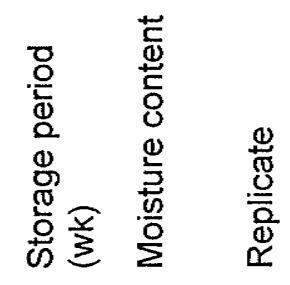

Percent of seeds infected by

\begin{tabular}{|c|c|c|c|c|c|c|c|c|c|c|c|c|c|}
\hline & & & 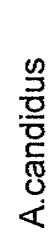 & 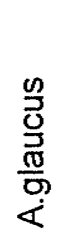 & 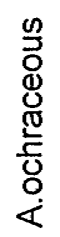 & $\begin{array}{l}\bar{E} \\
\overline{0} \\
\frac{1}{10} \\
\dot{\alpha}\end{array}$ & 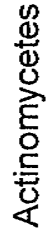 & 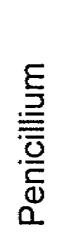 & 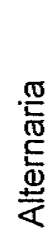 & 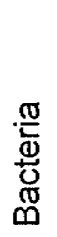 & 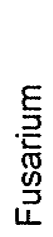 & $\begin{array}{l}\frac{5}{0} \\
\frac{0}{0} \\
\frac{0}{0} \\
\frac{0}{8} \\
\end{array}$ & 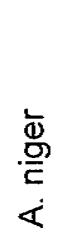 \\
\hline \multirow[t]{18}{*}{4} & 15 & $a$ & 24 & 32 & 20 & & & 36 & 4 & 20 & & & 4 \\
\hline & & $b$ & 8 & 20 & 32 & & & 40 & & 32 & & & \\
\hline & & $c$ & 16 & 40 & 32 & & & 28 & & 32 & & & 4 \\
\hline & 16 & $a$ & 24 & 16 & 32 & & & 56 & 4 & 32 & & & \\
\hline & & $b$ & 32 & 28 & 20 & & & 56 & 4 & 20 & & & 4 \\
\hline & & c & 28 & 28 & 24 & & & 48 & & 24 & & & \\
\hline & 17 & a & 44 & & 24 & & & 52 & & 24 & & & \\
\hline & & $b$ & 28 & & 24 & & & 60 & & 24 & & & \\
\hline & & C & 44 & 8 & 12 & & & 68 & & 12 & & & \\
\hline & 18 & a & & 16 & 12 & & & 64 & & 12 & & & \\
\hline & & $b$ & 12 & 20 & 16 & & & 76 & & 16 & & & \\
\hline & & $\mathrm{c}$ & 12 & 16 & 32 & & & 56 & & 32 & & & \\
\hline & 19 & $a$ & 8 & 4 & 24 & & & 60 & & 24 & & & \\
\hline & & $b$ & 32 & 16 & 32 & & & 52 & & 32 & & & \\
\hline & & C & 20 & 16 & 32 & & & 56 & & 32 & & & \\
\hline & 20 & $a$ & 36 & 28 & 24 & & & 64 & & 24 & & & \\
\hline & & $b$ & 36 & 28 & 24 & & & 64 & & 24 & & & \\
\hline & & c & 16 & 24 & 16 & & & 68 & & 16 & & & \\
\hline
\end{tabular}




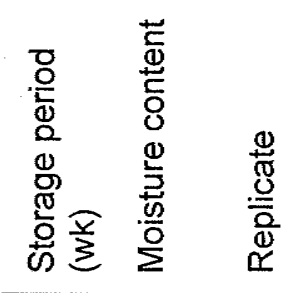

Percent of seeds infected by

\begin{tabular}{|c|c|c|c|c|c|c|c|c|c|c|c|c|c|}
\hline & & & 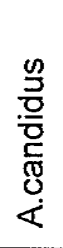 & 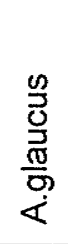 & 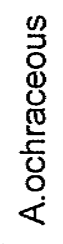 & 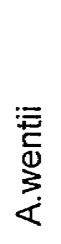 & 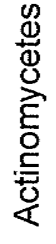 & 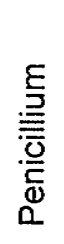 & 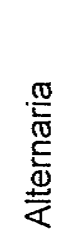 & $\begin{array}{l}\cdot \frac{\mathbb{N}}{\mathbb{D}} \\
\stackrel{\mathbb{D}}{\mathbb{D}} \\
\mathbb{\infty}\end{array}$ & 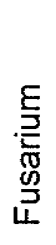 & $\begin{array}{l}\frac{\overline{0}}{0} \\
\frac{.0}{0} \\
\frac{0}{0} \\
2 \\
\dot{\alpha}\end{array}$ & 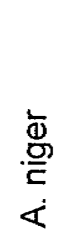 \\
\hline \multirow[t]{18}{*}{6} & 15 & a & 20 & 64 & 24 & & & 56 & & 40 & & & \\
\hline & & $b$ & & 88 & 12 & & & 60 & & 40 & & & \\
\hline & & $c$ & 16 & 80 & 12 & & & 60 & & 40 & & & \\
\hline & 16 & a & 28 & 16 & 8 & & & 40 & & 56 & & & \\
\hline & & $b$ & 52 & 32 & 12 & & & 40 & & 52 & & & \\
\hline & & $c$ & 12 & 40 & 8 & & & 52 & & 100 & & & \\
\hline & 17 & $a$ & 76 & 60 & 8 & & & 48 & & 60 & & & \\
\hline & & $b$ & 84 & 40 & 12 & & & 40 & & 64 & & & \\
\hline & & c & 56 & 16 & & & & 28 & & 28 & & & \\
\hline & 18 & a & 64 & 24 & & & & 32 & & 28 & & & \\
\hline & & b & 60 & 40 & 12 & & & 72 & & 60 & & & \\
\hline & & c & 76 & 8 & & & & 40 & & 40 & & & \\
\hline & 19 & a & 44 & & & & & 60 & 12 & 40 & & & \\
\hline & & b & 60 & 12 & & & & 56 & 28 & 40 & & & \\
\hline & & $c$ & 60 & 8 & & & & 60 & 8 & 40 & & & \\
\hline & 20 & a & 4 & 8 & & & & 60 & 8 & 20 & & & \\
\hline & & $b$ & 28 & 12 & 12 & & & 80 & 40 & 52 & & & \\
\hline & & c & 12 & 8 & 8 & & & 64 & 12 & 12 & & & \\
\hline
\end{tabular}




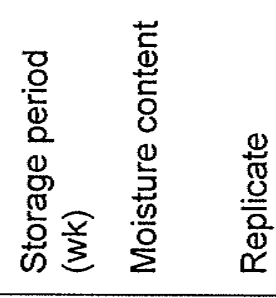

Percent of seeds infected by

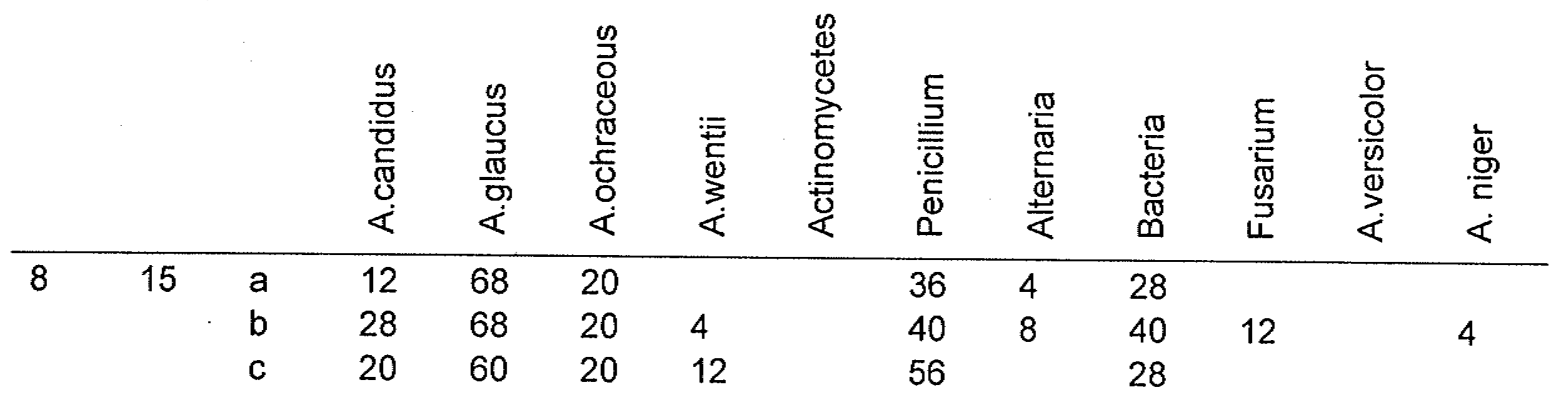

$\begin{array}{llllll}16 & \text { a } & 32 & 44 & 16 & 4 \\ & \mathrm{~b} & 36 & 40 & 8 & \\ \mathrm{c} & 40 & 48 & 16\end{array}$

$\begin{array}{lll}4 & 44 & 32\end{array}$

$\begin{array}{llll}36 & & 32 & 8 \\ 52 & 4 & 40 & 8\end{array}$

$\begin{array}{lllll}17 & \text { a } & 80 & 44 & 12 \\ \text { b } & 92 & 60 & 16 \\ \text { c } & 36 & 24 & 16\end{array}$

$\begin{array}{lll}16 & 12 & 4\end{array}$

$\begin{array}{lll}36 & 24 & 12\end{array}$

$\begin{array}{lll}12 & 32 & 12\end{array}$

$\begin{array}{llll}18 & \text { a } & 56 & 16 \\ \text { b } & 12 & \\ \text { c } & 32 & \end{array}$

$\begin{array}{llll}60 & 12 & 60 & 4 \\ 20 & 8 & 32 & \end{array}$

$\begin{array}{lll}19 & a & \\ & b & 4\end{array}$

4

$\begin{array}{lllll} & 60 & 12 & 60 & 4 \\ & 20 & 8 & 32 & \\ 4 & & 8 & \end{array}$

c 8

4

$\begin{array}{ll}8 & 8 \\ 24 & 4\end{array}$

$\begin{array}{llll}20 & a & 12 & 8 \\ b & 16 & 4 \\ & c & 8 & \end{array}$

$\begin{array}{llll} & 8 & 4 & \\ 4 & 12 & & \\ 4 & 12 & 4 & 8\end{array}$




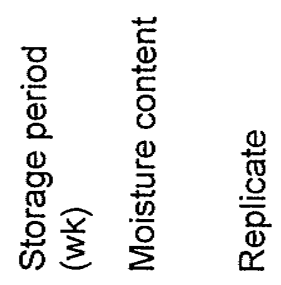

Percent of seeds infected by

\begin{tabular}{|c|c|c|c|c|c|c|c|c|c|c|c|c|c|}
\hline & & & 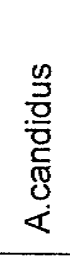 & 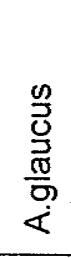 & 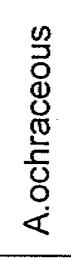 & 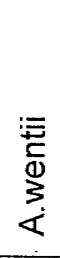 & 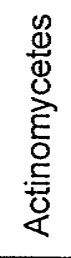 & $\begin{array}{l}\frac{E}{D} \\
\overline{\overline{\bar{O}}} \\
\frac{\overline{0}}{\bar{D}} \\
\square\end{array}$ & 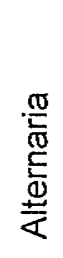 & 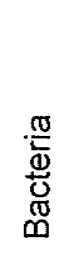 & 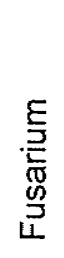 & $\begin{array}{l}\frac{\overline{0}}{0} \\
\frac{.0}{0} \\
\frac{0}{0} \\
\frac{8}{\alpha}\end{array}$ & 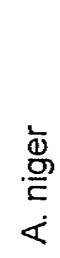 \\
\hline \multirow[t]{18}{*}{10} & 15 & $a$ & 12 & 68 & 20 & & & 365 & 4 & 28 & & & \\
\hline & & $b$ & 28 & 68 & 20 & 4 & & 40 & 8 & 40 & 12 & & 4 \\
\hline & & c & 20 & 60 & 20 & 12 & & 56 & & 28 & & & \\
\hline & 16 & a & 32 & 44 & 16 & 4 & & 44 & & 32 & & & \\
\hline & & b & 26 & 40 & 8 & & & 36 & & 32 & 8 & & \\
\hline & & c & 40 & 48 & 16 & & & 52 & 4 & 40 & 8 & & \\
\hline & 17 & a & 80 & 44 & 12 & & & 16 & & 12 & & 4 & \\
\hline & & $b$ & 92 & 60 & 16 & & & 32 & & 24 & 12 & & \\
\hline & & c & 36 & 24 & 16 & & & 12 & & 32 & 12 & & \\
\hline & 18 & a & 56 & 16 & & & & 60 & 12 & 60 & 4 & & \\
\hline & & $b$ & 12 & & & & & 20 & 8 & 32 & & & \\
\hline & & C & 32 & & & 4 & & & 8 & & & & \\
\hline & 19 & $a$ & & & & & & 8 & & & & & \\
\hline & & b & 4 & & & & 8 & 4 & & & & & \\
\hline & & c & 8 & & 4 & & 24 & 20 & & & & & \\
\hline & 20 & a & 12 & 8 & & & & 8 & 4 & & & & \\
\hline & & b & 16 & 4 & & & & 12 & & & & & \\
\hline & & $c$ & 8 & & 4 & & & 12 & 4 & 8 & & & \\
\hline
\end{tabular}




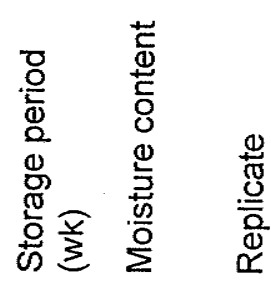

Percent of seeds infected by

\begin{tabular}{|c|c|c|c|c|c|c|c|c|c|c|c|c|c|}
\hline & & & 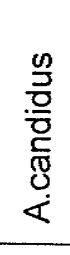 & $\begin{array}{l}\frac{n}{3} \\
0 \\
\frac{\pi}{\pi} \\
\frac{\pi}{0} \\
\dot{\alpha}\end{array}$ & 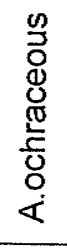 & $\begin{array}{l}:= \\
\overline{\overline{0}} \\
\overline{0} \\
\bar{\zeta}\end{array}$ & 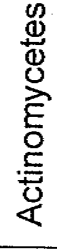 & 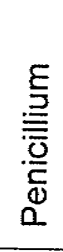 & 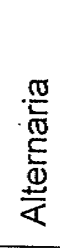 & 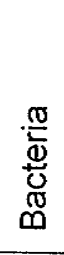 & 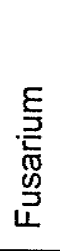 & 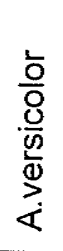 & $\begin{array}{l}\frac{1}{\mathscr{J}} \\
\stackrel{.}{\mathrm{C}} \\
\dot{\alpha}\end{array}$ \\
\hline \multirow[t]{18}{*}{12} & 15 & a & 36 & 64 & 8 & & & 44 & & & & & \\
\hline & & $b$ & 48 & 72 & & & & 24 & & 12 & & 12 & \\
\hline & & c & 28 & 72 & & & & 24 & 8 & & & 12 & \\
\hline & 16 & a & 60 & 60 & 4 & & & 32 & & & & 8 & \\
\hline & & b & 48 & 32 & 16 & & & 36 & 4 & 16 & & 12 & \\
\hline & & $c$ & 52 & 40 & & & 4 & 20 & & 4 & & 8 & \\
\hline & 17 & $a$ & 56 & 40 & 8 & 4 & & 8 & & 8 & & 4 & \\
\hline & & $b$ & 68 & 40 & & & 4 & 16 & & 20 & & 4 & \\
\hline & & c & 68 & 20 & 12 & & 8 & & & 16 & & & \\
\hline & 18 & $a$ & 8 & 8 & 12 & 4 & 4 & 20 & & 28 & & & \\
\hline & & b & 16 & & 4 & & 8 & 8 & & 20 & & & \\
\hline & & $c$ & 28 & & & & & & & 28 & & & \\
\hline & 19 & a & 60 & 4 & & & & & & 40 & & & \\
\hline & & b & 36 & 4 & & & & & & 48 & & & \\
\hline & & c & 28 & 28 & & & & & & 24 & & & \\
\hline & 20 & a & 20 & 28 & 8 & & & 12 & & 24 & & & \\
\hline & & $b$ & 20 & 4 & 4 & & & & & 12 & & & \\
\hline & & $c$ & 36 & 16 & & & & 16 & & 12 & & & \\
\hline
\end{tabular}


APPENDIX D: Fatty acid value data 
Table D1. FAV of durum wheat stored at $10^{\circ} \mathrm{C}$

\begin{tabular}{|c|c|c|c|c|c|c|c|}
\hline \multicolumn{8}{|c|}{ Moisture content $(\% \mathrm{wb})$} \\
\hline $\begin{array}{l}\text { Storage Period } \\
\text { (wk) }\end{array}$ & Replicate & 15.0 & 16.0 & 17.0 & 18.0 & 19.0 & 20.0 \\
\hline \multirow{5}{*}{2} & a & 20.6 & 22.9 & 21.1 & 26.9 & 15.3 & 17.8 \\
\hline & b & 25.5 & 19.8 & 21.3 & 24.2 & 17.8 & 15.3 \\
\hline & $\mathrm{c}$ & 17.9 & 20.8 & 26.5 & 20.4 & 17.8 & 20.4 \\
\hline & mean & 21.33 & 21.17 & 22.97 & 23.83 & 16.97 & 17.83 \\
\hline & s.d. & 3.85 & 1.58 & 3.06 & 3.26 & 1.44 & 2.55 \\
\hline \multirow{5}{*}{4} & a & 30.6 & 28.0 & 33.1 & 33.1 & 28.6 & 35.2 \\
\hline & $b$ & 28.0 & 33.1 & 51.5 & 44.1 & 25.5 & 30.1 \\
\hline & $\mathrm{c}$ & 25.5 & 34.5 & 28.0 & 36.9 & 34.2 & 29.5 \\
\hline & mean & 28.03 & 31.87 & 37.53 & 38.03 & 29.43 & 31.60 \\
\hline & s.d. & 2.55 & 3.42 & 12.36 & 5.59 & 4.41 & 3.13 \\
\hline \multirow{5}{*}{6} & a & 43.1 & 56.0 & 48.4 & 38.2 & 68.8 & 43.3 \\
\hline & b & 48.9 & 68.8 & 45.8 & 35.7 & 63.7 & 50.9 \\
\hline & $\mathrm{c}$ & 45.8 & 50.9 & 43.3 & 45.8 & 61.1 & 48.4 \\
\hline & mean & 45.93 & 58.57 & 45.83 & 39.90 & 64.53 & 47.53 \\
\hline & s.d. & 2.90 & 9.22 & 2.55 & 5.27 & 3.92 & 3.87 \\
\hline \multirow{5}{*}{8} & a & 22.9 & 22.9 & 17.8 & 17.8 & 30.6 & 48.4 \\
\hline & $b$ & 25.5 & 20.4 & 20.4 & 20.4 & 30.6 & 48.4 \\
\hline & $\mathrm{c}$ & 22.9 & 20.4 & 20.4 & 20.4 & 35.7 & 40.6 \\
\hline & mean & 23.77 & 21.23 & 19.53 & 19.53 & 32.30 & 45.8 \\
\hline & s.d. & 1.50 & 1.44 & 1.50 & 1.50 & 2.94 & 4.50 \\
\hline \multirow{5}{*}{10} & $\mathrm{a}$ & 25.5 & 28.0 & 22.9 & 25.5 & 53.5 & 68.8 \\
\hline & b & 30.6 & 22.9 & 28.0 & 28.0 & 43.3 & 61.1 \\
\hline & $\mathrm{c}$ & 25.5 & 28.0 & 25.5 & 30.6 & 48.4 & 63.7 \\
\hline & mean & 27.20 & 26.30 & 25.47 & 28.03 & 48.40 & 64.53 \\
\hline & s.d. & 2.94 & 2.94 & 2.55 & 2.55 & 5.10 & 3.91 \\
\hline \multirow{5}{*}{12} & a & 35.7 & 30.6 & 28.0 & 33.1 & 66.2 & 76.4 \\
\hline & $\mathrm{b}$ & 30.6 & 40.8 & 28.0 & 25.5 & 66.2 & 78.9 \\
\hline & $\mathrm{c}$ & 25.5 & 28.0 & 25.5 & 28.0 & 66.2 & 81.5 \\
\hline & mean & 30.60 & 33.13 & 27.17 & 28.87 & 66.20 & 78.93 \\
\hline & s.d. & 5.10 & 6.77 & 1.44 & 3.87 & 0.00 & 2.55 \\
\hline
\end{tabular}


Table D2. FAV of durum wheat stored at $20^{\circ} \mathrm{C}$

\begin{tabular}{|c|c|c|c|c|c|c|c|}
\hline \multicolumn{8}{|c|}{ Moisture content $(\% \mathrm{wb})$} \\
\hline $\begin{array}{l}\text { Storage Period } \\
\text { (wk) }\end{array}$ & Replicate & 15.0 & 16.0 & 17.0 & 18.0 & 19.0 & 20.0 \\
\hline \multirow{5}{*}{2} & a & 7.6 & 10.2 & 5.1 & 5.1 & 10.2 & 12.7 \\
\hline & b & 10.2 & 10.2 & 7.6 & 7.6 & 10.2 & 7.6 \\
\hline & $\mathrm{c}$ & 7.6 & 10.2 & 5.1 & 5.1 & 7.6 & 10.2 \\
\hline & méan & 8.47 & 10.20 & 5.93 & 5.93 & 9.33 & 10.17 \\
\hline & s.d. & 1.50 & 0.00 & 1.44 & 1.44 & 1.50 & 2.55 \\
\hline \multirow{4}{*}{4} & a & 15.3 & 10.2 & 7.6 & 15.3 & 28.0 & 17.8 \\
\hline & b & 12.7 & 7.6 & 12.7 & 17.8 & 20.1 & 20.1 \\
\hline & $\mathrm{c}$ & 12.7 & 7.6 & 12.7 & 20.2 & 22.9 & 28.0 \\
\hline & mean & 13.57 & 8.47 & 11.00 & 17.77 & 23.67 & 21.97 \\
\hline . & s.d. & 1.50 & 1.50 & 2.94 & 2.45 & 4.00 & 5.35 \\
\hline \multirow{5}{*}{6} & a & 20.4 & 12.7 & 12.7 & 7.6 & 10.2 & 17.8 \\
\hline & b & 17.8 & 10.2 & 5.1 & 10.2 & 10.2 & 12.7 \\
\hline & c & 22.9 & 12.7 & 7.6 & 5.1 & 7.6 & 10.2 \\
\hline & mean & 20.36 & 11.87 & 8.47 & 7.63 & 9.33 & 13.56 \\
\hline & s.d. & 2.55 & 1.44 & 3.87 & 2.55 & 1.50 & 3.87 \\
\hline \multirow{5}{*}{8} & a & 2.5 & 7.6 & 28.0 & 43.3 & 33.1 & 33.1 \\
\hline & b & 5.1 & 5.1 & 38.2 & 40.8 & 25.5 & 33.1 \\
\hline & $\mathrm{c}$ & 2.5 & 5.1 & 33.1 & 35.7 & 28.0 & 30.6 \\
\hline & mean & 3.36 & 5.93 & 33.1 & 39.93 & 28.87 & 32.27 \\
\hline & s.d. & 1.50 & 1.44 & 5.10 & 3.87 & 3.87 & 1.44 \\
\hline \multirow{5}{*}{10} & a & 5.1 & 10.2 & 17.8 & 28.0 & 25.5 & 33.1 \\
\hline & b & 10.2 & 5.1 & 17.8 & 25.5 & 25.5 & 38.2 \\
\hline & $\mathrm{c}$ & 7.6 & 12.7 & 20.4 & 33.1 & 28.0 & 30.6 \\
\hline & mean & 7.63 & 9.33 & 18.67 & 28.87 & 26.33 & 33.96 \\
\hline & s.d. & 2.55 & 3.87 & 1.50 & 3.87 & 1.44 & 3.87 \\
\hline \multirow{5}{*}{12} & $\mathrm{a}$ & 10.2 & 12.7 & 20.2 & 30.6 & 22.9 & 28.0 \\
\hline & b & 12.7 & 12.7 & 20.2 & 28.0 & 25.5 & 30.6 \\
\hline & $\mathrm{c}$ & 12.7 & 12.7 & 20.2 & 25.5 & 28.0 & 30.6 \\
\hline & mean & 11.87 & 12.70 & 20.20 & 28.03 & 25.47 & 29.73 \\
\hline & s.d. & 1.44 & 0.00 & 0.00 & 2.55 & 2.55 & 1.50 \\
\hline
\end{tabular}


Table D3. FAV of durum wheat stored at $30^{\circ} \mathrm{C}$

\begin{tabular}{|c|c|c|c|c|c|c|c|}
\hline \multicolumn{8}{|c|}{ Moisture content $(\% \mathrm{wb})$} \\
\hline $\begin{array}{l}\text { Storage Period } \\
\text { (wk) }\end{array}$ & Replicate & 15.0 & 16.0 & 17.0 & 18.0 & 19.0 & 20.0 \\
\hline \multirow{5}{*}{2} & a & 7.6 & 12.7 & 20.4 & 28.0 & 20.4 & 12.7 \\
\hline & b & 7.6 & 7.6 & 15.3 & 20.4 & 12.7 & 17.8 \\
\hline & $\mathrm{c}$ & 10.2 & 10.2 & 12.7 & 15.3 & 12.7 & 15.3 \\
\hline & mean & 8.47 & 10.17 & 16.13 & 21.23 & 15.27 & 15.26 \\
\hline & s.d. & 1.50 & 2.55 & 3.92 & 6.39 & 4.44 & 2.55 \\
\hline \multirow{5}{*}{4} & a & 15.3 & 12.7 & 35.7 & 48.4 & 58.6 & 45.8 \\
\hline & $\mathrm{b}$ & 10.2 & 15.3 & 33.1 & 53.5 & 50.9 & 48.4 \\
\hline & $\mathrm{c}$ & 12.7 & 17.8 & 25.5 & 56.0 & 48.4 & 50.9 \\
\hline & mean & 12.73 & 15.27 & 31.43 & 52.63 & 52.63 & 48.37 \\
\hline & s.d. & 2.55 & 2.55 & 5.30 & 3.87 & 5.31 & 2.55 \\
\hline \multirow{5}{*}{6} & $\mathrm{a}$ & 17.8 & 28.0 & 35.7 & 25.5 & 20.4 & 43.3 \\
\hline & $\mathrm{b}$ & 15.3 & 25.5 & 35.7 & 15.3 & 17.8 & 35.7 \\
\hline & $\mathrm{c}$ & 12.7 & 22.9 & 33.1 & 20.4 & 22.9 & 38.2 \\
\hline & mean & 15.27 & 25.47 & 34.83 & 20.40 & 20.37 & 39.07 \\
\hline & s.d. & 2.55 & 2.55 & 1.50 & 5.10 & 2.55 & 3.87 \\
\hline \multirow{5}{*}{8} & a & 28.0 & 28.0 & 40.8 & 30.6 & 43.3 & 30.6 \\
\hline & $\mathrm{b}$ & 30.6 & 38.2 & 45.8 & 38.2 & 43.3 & 38.2 \\
\hline & $\mathrm{c}$ & 22.9 & 35.7 & 45.8 & 33.1 & 43.3 & 35.7 \\
\hline & mean & 27.17 & 33.97 & 44.13 & 33.97 & 43.30 & 34.83 \\
\hline & s.d. & 3.92 & 5.31 & 2.89 & 3.87 & 0.00 & 3.87 \\
\hline \multirow{5}{*}{10} & a & 30.6 & 35.7 & 33.1 & 22.9 & 15.3 & 22.9 \\
\hline & b & 33.1 & 33.1 & 35.7 & 28.0 & 12.7 & 35.7 \\
\hline & $\mathrm{c}$ & 28.0 & 30.6 & 35.7 & 33.1 & 12.7 & 28.0 \\
\hline & mean & 30.57 & 33.13 & 34.83 & 28.00 & 13.57 & 28.87 \\
\hline & s.d. & 2.55 & 2.55 & 1.50 & 5.10 & 1.50 & 6.44 \\
\hline \multirow{5}{*}{12} & a & 22.9 & 33.1 & 25.5 & 25.5 & 20.4 & 30.6 \\
\hline & b & 20.4 & 33.1 & 33.1 & 22.9 & 25.5 & 25.5 \\
\hline & $\mathrm{c}$ & 28.0 & 28.0 & 28.0 & 25.5 & 20.4 & 28.0 \\
\hline & mean & 23.77 & 31.40 & 28.87 & 24.63 & 22.10 & 28.03 \\
\hline & s.d. & 3.87 & 2.94 & 3.87 & 1.50 & 2.94 & 2.55 \\
\hline
\end{tabular}


Table D4. FAV of durum wheat stored at $40^{\circ} \mathrm{C}$

\begin{tabular}{|c|c|c|c|c|c|c|c|}
\hline \multicolumn{8}{|c|}{ Moisture content ( $\%$ wb) } \\
\hline $\begin{array}{l}\text { Storage Period } \\
\text { (wk) }\end{array}$ & Replicate & 15.0 & 16.0 & 17.0 & 18.0 & 19.0 & 20.0 \\
\hline \multirow{5}{*}{2} & a & 28.0 & 50.9 & 73.9 & 89.1 & 84.0 & 30.6 \\
\hline & $\mathrm{b}$ & 25.5 & 50.9 & 73.9 & 84.0 & 81.5 & 28.0 \\
\hline & $\mathrm{c}$ & 25.5 & 43.3 & 78.9 & 96.8 & 81.5 & 28.0 \\
\hline & mean & 26.33 & 48.37 & 75.57 & 89.97 & 82.33 & 28.87 \\
\hline & s.d. & 1.44 & 4.39 & 2.89 & 6.44 & 1.44 & 1.50 \\
\hline \multirow{5}{*}{4} & a & 30.6 & 33.1 & 147.7 & 112.1 & 76.4 & 94.2 \\
\hline & $b$ & 30.6 & 43.3 & 150.3 & 114.6 & 86.6 & 106.9 \\
\hline & c & 33.1 & 45.8 & 152.8 & 117.2 & 71.3 & 104.4 \\
\hline & mean & 31.43 & 40.73 & 150.27 & 114.63 & 78.1 & 101.83 \\
\hline & s.d. & 1.44 & 6.73 & 2.55 & 2.55 & 7.79 & 6.73 \\
\hline \multirow{5}{*}{6} & $\mathrm{a}$ & 43.3 & 119.7 & 99.3 & 91.7 & 96.8 & 56.0 \\
\hline & $\mathrm{b}$ & 61.1 & 132.4 & 106.9 & 91.7 & 99.3 & 53.5 \\
\hline & $\mathrm{c}$ & 45.8 & 124.8 & 117.2 & 112.1 & 96.8 & 58.6 \\
\hline & mean & 50.07 & 125.63 & 107.8 & 98.50 & 97.63 & 56.03 \\
\hline & s.d. & 9.64 & 6.39 & 8.98 & 11.78 & 1.44 & 2.55 \\
\hline \multirow{5}{*}{8} & a & 106.9 & 127.3 & 114.6 & 81.5 & 40.8 & 43.3 \\
\hline & $\mathrm{b}$ & 99.3 & 96.8 & 96.8 & 71.3 & 58.6 & 45.8 \\
\hline & $\mathrm{c}$ & 81.5 & 129.9 & 81.5 & 76.4 & 50.9 & 35.7 \\
\hline & mean & 95.9 & 118.00 & 97.63 & 76.40 & 50.10 & 41.60 \\
\hline & s.d. & 13.03 & 18.41 & 16.57 & 5.10 & 8.93 & 5.26 \\
\hline \multirow{5}{*}{10} & a & 99.3 & 89.1 & 96.8 & 78.9 & 50.9 & 53.5 \\
\hline & b & 94.2 & 119.7 & 104.4 & 66.2 & 58.6 & 50.9 \\
\hline & $\mathrm{c}$ & 89.1 & 104.4 & 99.3 & 76.4 & 48.4 & 40.8 \\
\hline & mean & 94.20 & 104.4 & 100.17 & 73.83 & 52.63 & 48.40 \\
\hline & s.d. & 5.10 & 15.3 & 3.87 & 6.73 & 5.32 & 6.71 \\
\hline \multirow{5}{*}{12} & a & 140.0 & 150.3 & 119.7 & 73.9 & 66.2 & 63.7 \\
\hline & $\mathrm{b}$ & 122.3 & 145.2 & 140.1 & 78.9 & 66.2 & 58.6 \\
\hline & $c$ & 119.7 & 142.7 & 101.9 & 76.4 & 61.1 & 61.1 \\
\hline & mean & 127.33 & 146.07 & 120.57 & 76.40 & 64.50 & 61.13 \\
\hline & s.d. & 11.06 & 3.87 & 19.11 & 2.50 & 2.94 & 2.55 \\
\hline
\end{tabular}


APPENDIX E: Ochratoxin data 
Table E1. Ochratoxin in durum wheat stored at $10^{\circ} \mathrm{C}$ (Replicate 1)

\begin{tabular}{cccccccc}
\hline $\begin{array}{c}\text { Storage } \\
\text { Period } \\
(\mathrm{wk})\end{array}$ & $\begin{array}{c}\text { Mycotoxin } \\
(\mathrm{ppb})\end{array}$ & \multicolumn{7}{c}{ Moisture Content $(\% \mathrm{wb})$} \\
\hline 10 & OTA & $<10$ & 16 & 17 & 18 & 19 & 20 \\
\hline 10 & OT & $<10$ & $\operatorname{tr}$ & 110 & 400 \\
& OTB & $<10$ & $<10$ & $<10$ & $<10$ & $\operatorname{tr}$ & 23 \\
& Zearalenone & $<100$ & $<100$ & $<100$ & $<100$ & $<100$ & $<100$ \\
12 & & & & & & \\
& OTA & $<10$ & $<10$ & $<10$ & $<10$ & 68 & 76 \\
& OTB & $<10$ & $<10$ & $<10$ & $<10$ & $<10$ & $<10$ \\
& Zearalenone & $<100$ & $<100$ & $<100$ & $<100$ & $<100$ & $<100$ \\
\hline
\end{tabular}

Table E2. Ochratoxin in durum wheat stored at $20^{\circ} \mathrm{C}$ after 12 weeks

\begin{tabular}{cccccccc}
\hline $\begin{array}{c}\text { Mycotoxin } \\
(\mathrm{ppb})\end{array}$ & Replicate & \multicolumn{6}{c}{ Moisture Content $(\% \mathrm{wb})$} \\
\cline { 3 - 8 } & 1 & 15 & 16 & 17 & 18 & 19 & 20 \\
\hline OTA & 1 & $*$ & $*$ & $*$ & $*$ & $*$ & 192 \\
& 2 & $*$ & $*$ & $*$ & $*$ & $*$ & 154 \\
& 3 & $*$ & $*$ & $*$ & $*$ & $*$ & 135 \\
\hline
\end{tabular}

(* Analysis yet to be done) 